AUTARQUIA ASSOCIADA À UNIVERSIDADE DE SÃO PAULO

\author{
EXPRESSÃO DE TIREOTROFINA HUMANA EM \\ CÉLULAS DE EMBRIÃO DE RIM HUMANO (HEK293)
}

PATRÍCIA MARINHO SANT'ANA

Dissertação apresentada como parte dos requisitos para obtenção do Grau de Mestre em Ciências na Área de Tecnologia Nuclear - Aplicações

Orientadora:

Profa. Dra. Maria Teresa de C. P. Ribela 
Dedico este trabalho

À meus pais Sebastião Sant'Ana e Júlia Marinho Sant'Ana por todo carinho e dedicação.

À minha irmã Caroline Marinho Sant'Ana, que suportou os meus piores momentos e que me ajudou quando mais precisei.

À minha orientadora, Prof ${ }^{a}$ Maria Teresa C. P. Ribela, que apesar de toda turbulência me apoiou e me trouxe até aqui. Definitivamente eu não teria conseguido sem ela. 


\section{Agradecimentos}

Agradeço primeiramente a Deus, que me ajudou a suportar as dificuldades e chegar até aqui. Ao Dr. Paolo Bartolini, idealizador do projeto.

Ao Dr. Carlos Roberto Jorge Soares e à Dra. Cibele Nunes Peroni por toda ajuda no desenvolvimento deste trabalho e por todo conhecimento transmitido.

À Beatriz Elaine Almeida, que guiou os meus primeiros passos no laboratório.

À Eliana Rosa Lima Filha (vulgo “curica”), pela ajuda na realização dos testes com animais e por seus trocadilhos hilários.

À Thais Cristina Sevilhano, pelas dicas de PCR e pelas angústias divididas causadas por vetores e pessoas fechadas.

À Eliza Higuti, pelos cigarros doados, dicas de transfecção e cortes de cabelo gratuitos.

À Marina Lima, pelo carinho com que sempre me tratou.

À Paulo Vitor Dias, por ter me mostrado modernidades interessantes, mas que até o momento não consegui utilizar.

À Ed Carlos e Paula Juliana, pelos cafés no fim de tarde e pela ajuda profissional.

À Gustavo de Jesus e Felipe Douglas pela convivência amistosa.

Aos colegas Junqueira e Miriam Suzuki por estarem sempre prontos a ajudar.

Aos colegas João Ezequiel Oliveira, José Maria e Rosângela pela ajuda no processo de purificação.

Aos amigos Cristiane Aparecida Silva, Priscila Gimenez, Fábio Fortes, Clóvis Melo, Luis Dutra, Luiz Piva, Kelly Rosseti e Marlene Tursi, pela torcida, palavras de incentivo, preocupação e paciência.

À CAPES pelo apoio financeiro. 
INSTITUTO DE PESQUISAS ENERGÉTICAS E NUCLEARES

Autarquia associada à Universidade de São Paulo

\title{
EXPRESSÃO DE TIREOTROFINA EM \\ CÉLULAS DE EMBRIÃO DE RIM HUMANO (HEK293)
}

\author{
PATRÍCIA MARINHO SANT'ANA
}

Dissertação apresentada como parte dos requisitos para obtenção do Grau de Mestre em Ciências na Área de Tecnologia Nuclear - Aplicações

Orientadora:

Profa. Dra. Maria Teresa de C. P. Ribela

Versão Corrigida

Versão origiginal disponível no IPEN

São Paulo

2016 


\title{
EXPRESSÃO DE TIREOTROFINA HUMANA EM CÉLULAS DE EMBRIÃO DE RIM HUMANO (HEK 293)
}

\author{
Patrícia Marinho Sant'Ana
}

\section{RESUMO}

Neste trabalho foi transfectada uma linhagem de células embrionárias de rim humano (HEK293) com os genes das subunidades $\alpha$ e $\beta$ da tireotrofina humana (hTSH), hormônio glicoproteico secretado pela hipófise. Após 5 dias de cultivo obteve-se uma concentração de hTSH no meio condicionado de $0,95 \mu \mathrm{g} / \mathrm{mL}$. O material foi concentrado e purificado utilizando uma estratégia envolvendo duas etapas, uma cromatografia de troca catiônica e uma cromatografia líquida de alta eficiência (HPLC) de fase reversa, que permitiu uma recuperação de $55 \%$ e uma pureza $>90 \%$. O produto purificado (hTSH-HEK) foi analisado e comparado a uma preparação comercial obtida em células $\mathrm{CHO}$ (hTSH-CHO) e a uma preparação hipofisária (hTSH-Pit). A identidade e a pureza do hTSH-HEK foram avaliadas por métodos físicoquímicos e imunológico (espectrometria de massa MALDI-TOF, HPLC de exclusão molecular e de fase reversa, SDS-PAGE e ensaio imunoradiométrico). A porção glicídica do hTSH-HEK foi avaliada pela análise do perfil dos N-glicanos e o comportamento biológico deste hormônio foi avaliado por bioensaio in vivo e estudo farmacocinético. As 3 preparações apresentaram pureza equivalente (97\%) e a massa molecular relativa do hTSH-HEK foi $2,1 \%$ menor do que a do hTSH-CHO e 2,7\% maior do que a do hTSH-Pit. A maior hidrofobicidade relativa, avaliada por RP-HPLC, foi a do hTSH-HEK. Os N-glicanos identificados no hTSH-HEK foram do tipo complexo, apresentando predominantemente estruturas tri-antenárias, enquanto no hTSH-CHO e no hTSH-Pit as estruturas bi-antenárias foram predominantes. Foram detectadas diferenças significativas relacionadas à composição dos carboidratos para estas preparações, um teor muito menor de ácido siálico e muito maior de fucose foram observados no hTSHHEK. Foi confirmada a atividade biológica das 3 preparações, sendo a bioatividade do hTSHHEK $39 \%$ e $16 \%$ inferior à do hTSH-CHO e hTSH-Pit, respectivamente. A meia-vida circulatória do hTSH-HEK foi menor (1,5 X) que a do hTSH-CHO e a do hTSH-Pit (1,2 X). De acordo com esses resultados o hTSH-HEK pode ser considerado uma alternativa viável para aplicações clínicas especialmente por sua origem humana e composição de carboidratos. 


\title{
HUMAN TRYROTROPIN EXPRESSION IN HUMAN EMBRIONIC KIDNEY CELLS (HEK293)
}

\author{
Patrícia Marinho Sant'Ana
}

\begin{abstract}
In this work a strain of embryonic human kidney cells (HEK293) was transfected with the genes of the $\alpha$ and $\beta$ subunits of human thyrotropin (hTSH), a glycoproteic hormone secreted by the pituitary gland. After 5 days of culture, the concentration of hTSH in conditioned medium was $0.95 \mu \mathrm{g} / \mathrm{mL}$. The material was concentrated and purified utilizing a strategy involving two steps, a cation-exchange chromatography and a reversed phase high performance liquid chromatography (RP-HPLC), providing an overall yield of 55\% and a purity level $>90 \%$. The purified material (hTSH-HEK) was analyzed and compared to a recombinant commercial preparation obtained from $\mathrm{CHO}$ cells (hTSH-CHO) and to a human pituitary preparation (hTSH-Pit). Identity and purity of hTSH-HEK were evaluated through physicochemical and immunological methods (MALDI-TOF mass spectrometry, size exclusion HPLC, reversed-phase HPLC, SDS-PAGE, immunoradiometric assay). Glycidic portion of hTSHHEK was evaluated by $\mathrm{N}$-glycoprofiling analysis and the biological behavior of this hormone was evaluated by an in vivo bioassay and via a pharmacokinetic study. The 3 preparations showed equivalent purity (97\%) and hTSH-HEK molecular mass was $2.1 \%$ lower than hTSHCHO mass and $2.7 \%$ higher than hTSH-Pit mass. The highest relative hydrophobicity, evaluated by RP-HPLC, was shown by hTSH-HEK. Remarkable differences related to the carbohydrate moiety were found for these preparations, a much lower sialic acid content and a higher fucose content being observed in hTSH-HEK. Biological activity was confirmed for the three preparations, the hTSH-HEK bioactivity being $39 \%$ and $16 \%$ lower than hTSH-CHO and hTSH-Pit, respectively. The hTSH-HEK circulatory half-life $\left(\mathrm{t}_{1 / 2}\right)$ was lower than that of hTSHCHO (1.5-fold) and hTSH-Pit (1.2-fold). According to these findings, HEK293-derived hTSH can be considered useful for clinical applications, also in view of its human origin and particular $\mathrm{N}$-glycan composition.
\end{abstract}




\section{SUMÁRIO}

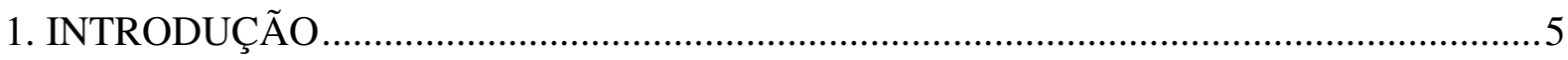

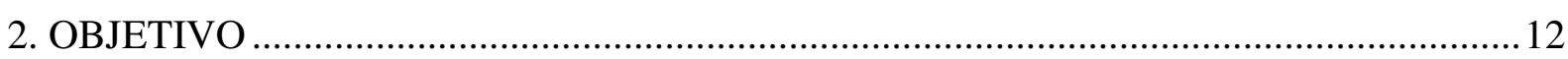

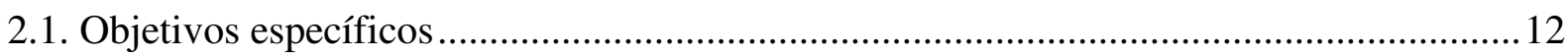

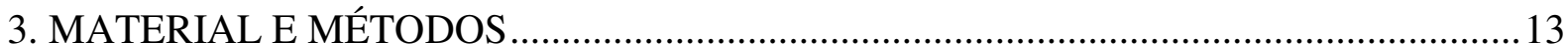

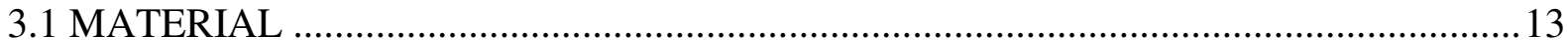

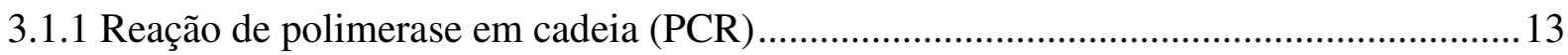

3.1.2 Vetor de expressão.........................................................................................13

3.1.3 Transformação de células competentes ......................................................................13

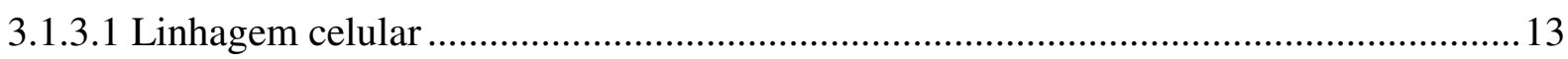

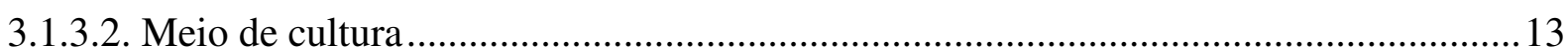

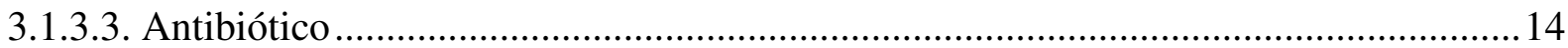

3.1.4. Kits de extração e purificação de DNA plasmidial ........................................................14

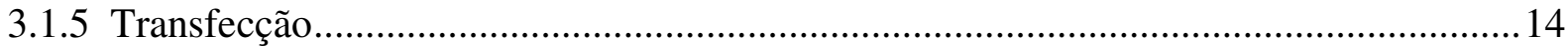

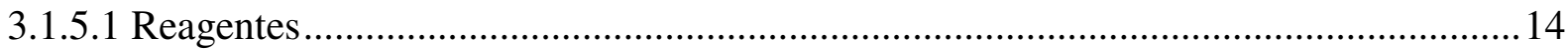

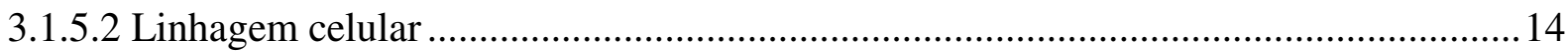

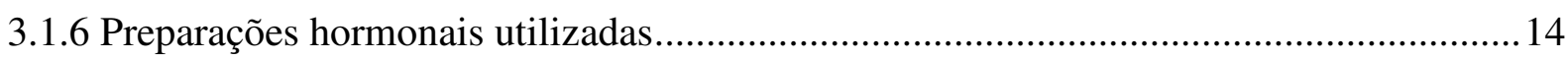

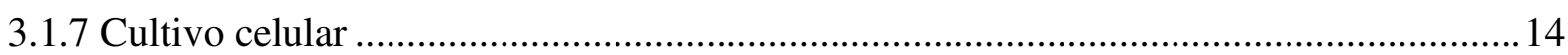

3.1.7.1 Reagentes utilizados nos procedimentos de cultura celular .......................................... 14

3.1.7.2 Material plástico estéril .................................................................................15

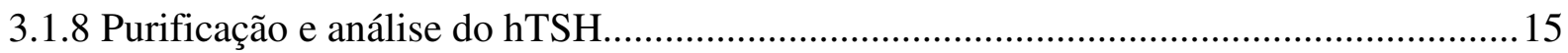

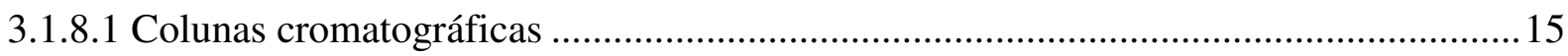

a) Coluna de vidro utilizada em cromatografia clássica.........................................................15

b) Colunas cromatográficas utilizadas na cromatografia líquida de alta eficiência (HPLC) ...15

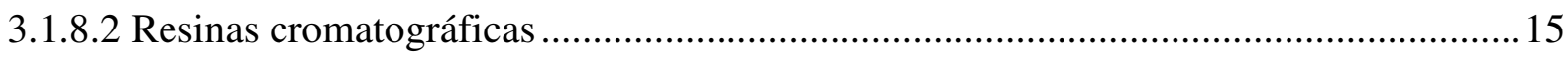

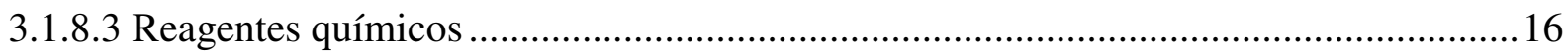

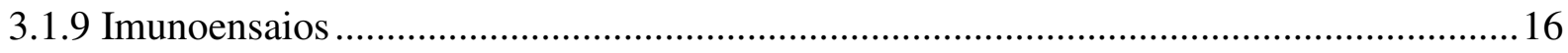

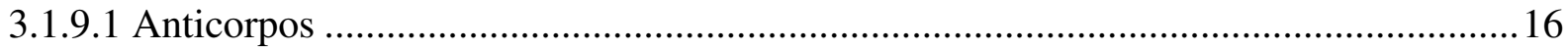

3.1.9.2 Reagentes para marcação do anticorpo de detecção.......................................................16

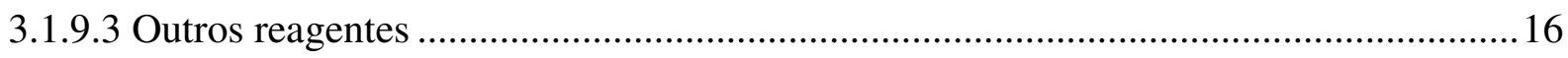

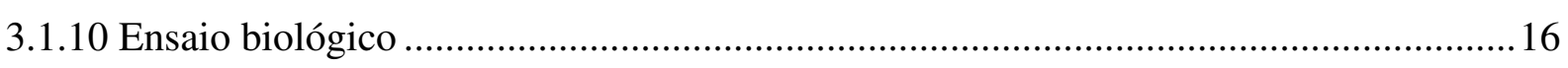

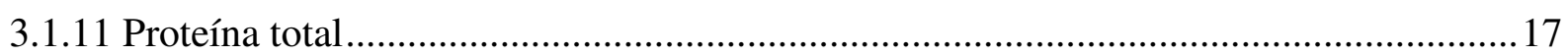

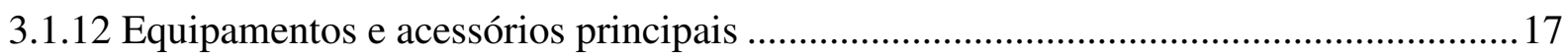

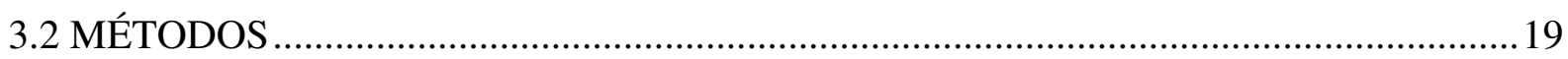

3.2.1 Obtenção da região codificadora das subunidades $\alpha$ e $\beta$ do TSH humano........................19 


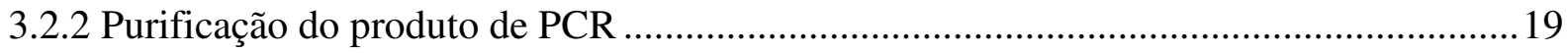

3.2.3 Clonagem das subunidades no vetor de expressão ...................................................20

3.2.4 Transformação das células competentes pelo método do choque térmico ......................21

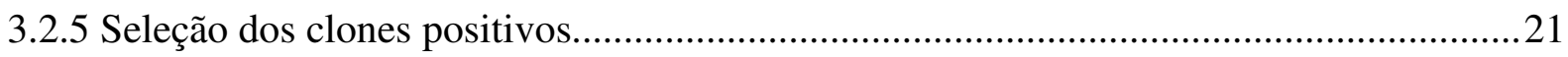

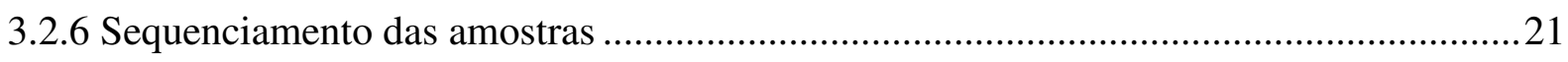

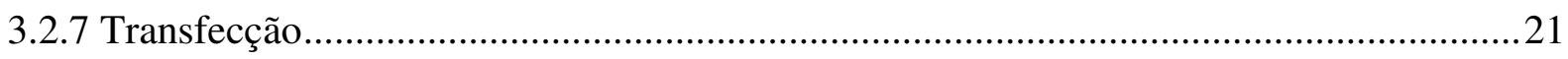

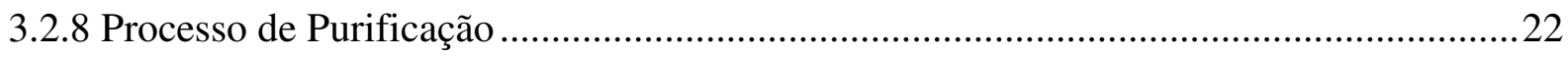

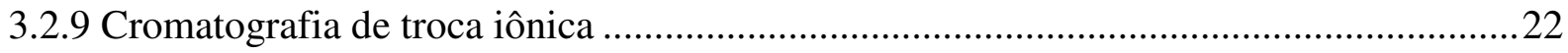

3.2.10 Cromatografia líquida de alta eficiência em fase reversa preparativa (RP-HPLC).......23

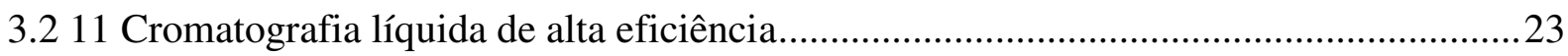

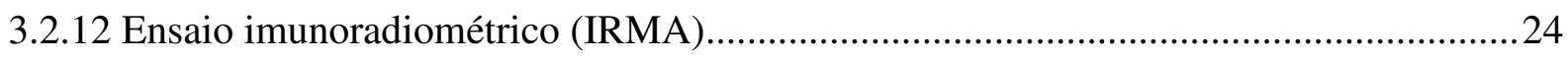

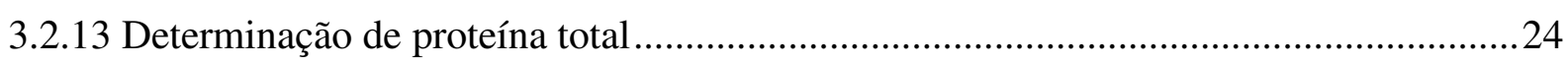

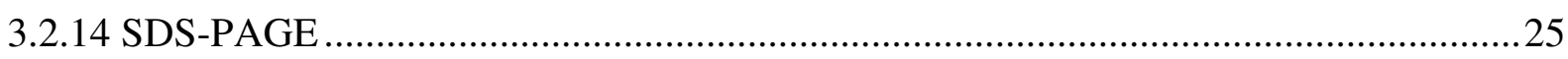

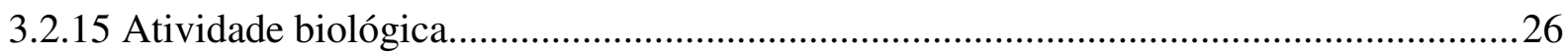

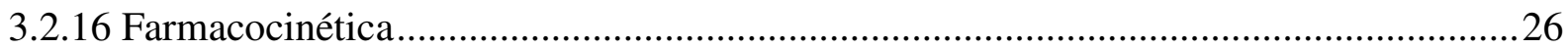

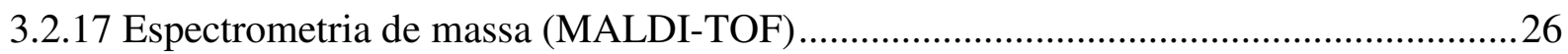

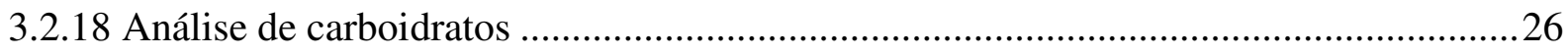

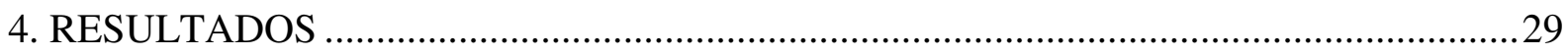

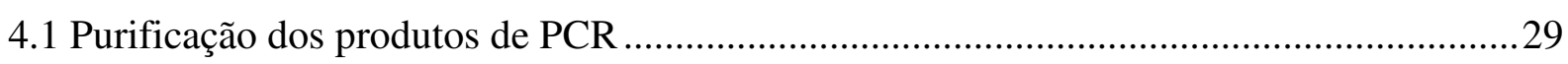

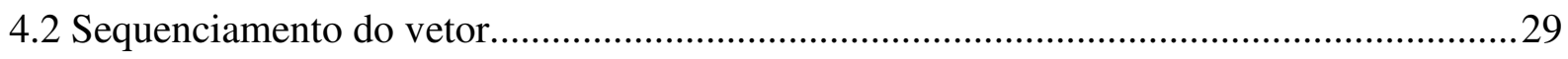

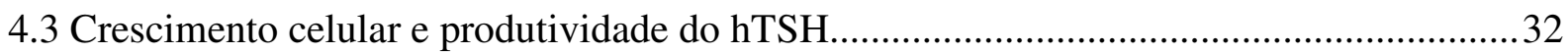

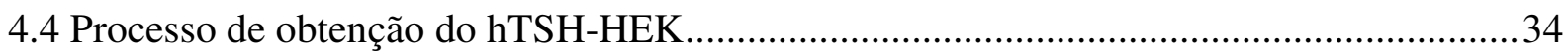

4.5 Caracterização do Produto Purificado e Sua Comparação com Preparações de Diferentes

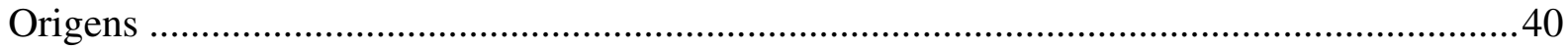

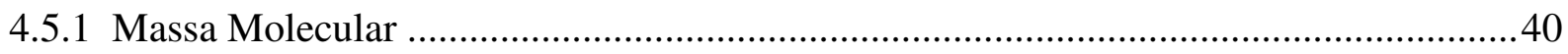

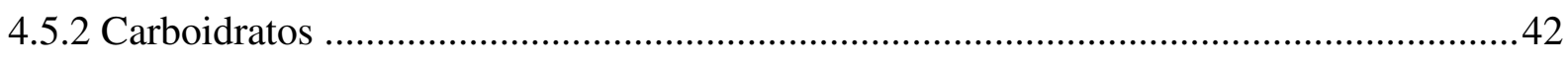

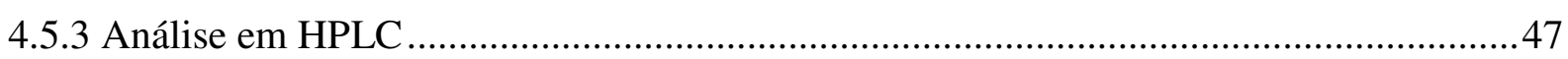

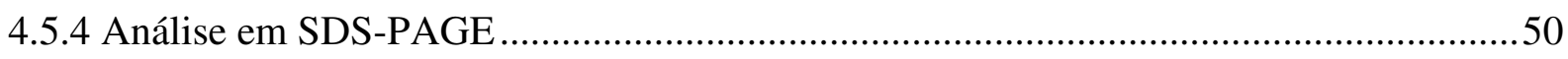

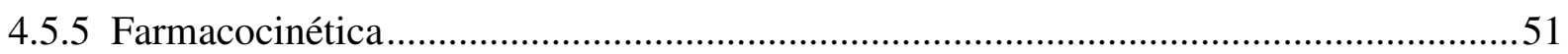

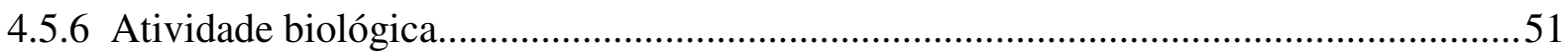

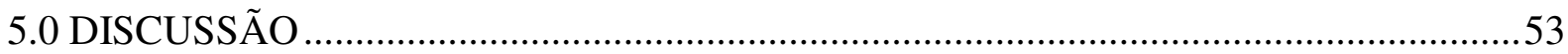

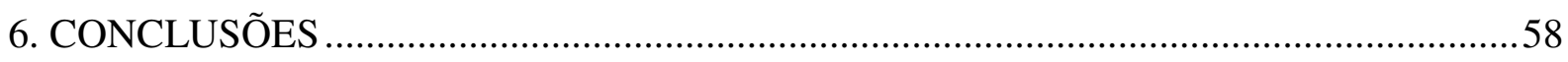

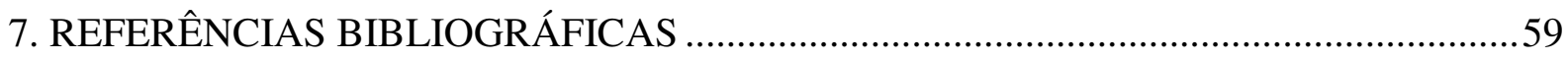




\section{INTRODUÇÃO}

A produção de proteínas recombinantes ganhou muita importância nos últimos 20 anos, sendo o principal foco a obtenção de produtos biofarmacêuticos (anticorpos monoclonais, hormônios e diversas proteínas de fusão).

De um modo geral, os principais sistemas de expressão utilizados neste processo são: os microbiológicos (bactérias, fungos e leveduras), animais transgênicos, células de mamíferos, insetos ou vegetais. Vários fatores influenciam na escolha do hospedeiro, especialmente a capacidade de expressar proteínas mais complexas, glicosiladas.

Os sistemas microbiológicos são amplamente utilizados devido à facilidade de manejo, alto rendimento e menor custo de produção. Apesar das vantagens, não são indicados para expressar proteínas glicosiladas. Produtos recombinantes obtidos de bactérias apresentam pouca ou nenhuma glicosilação. As leveduras expressam produtos com estrutura de alta manose. Animais transgênicos podem ser utilizados como sistema de expressão alternativo, pois fornecem proteínas recombinantes de alta qualidade com um baixo custo de produção. No entanto, apresentam como desvantagem a dificuldade de purificar o produto recombinante e a possibilidade de contaminação com patógenos do animal. Os sistemas de expressão baseados em células de vegetais e de insetos podem produzir padrões de glicosilação totalmente diferentes ao humano, resultando em proteínas imunogênicas (Figura 1).

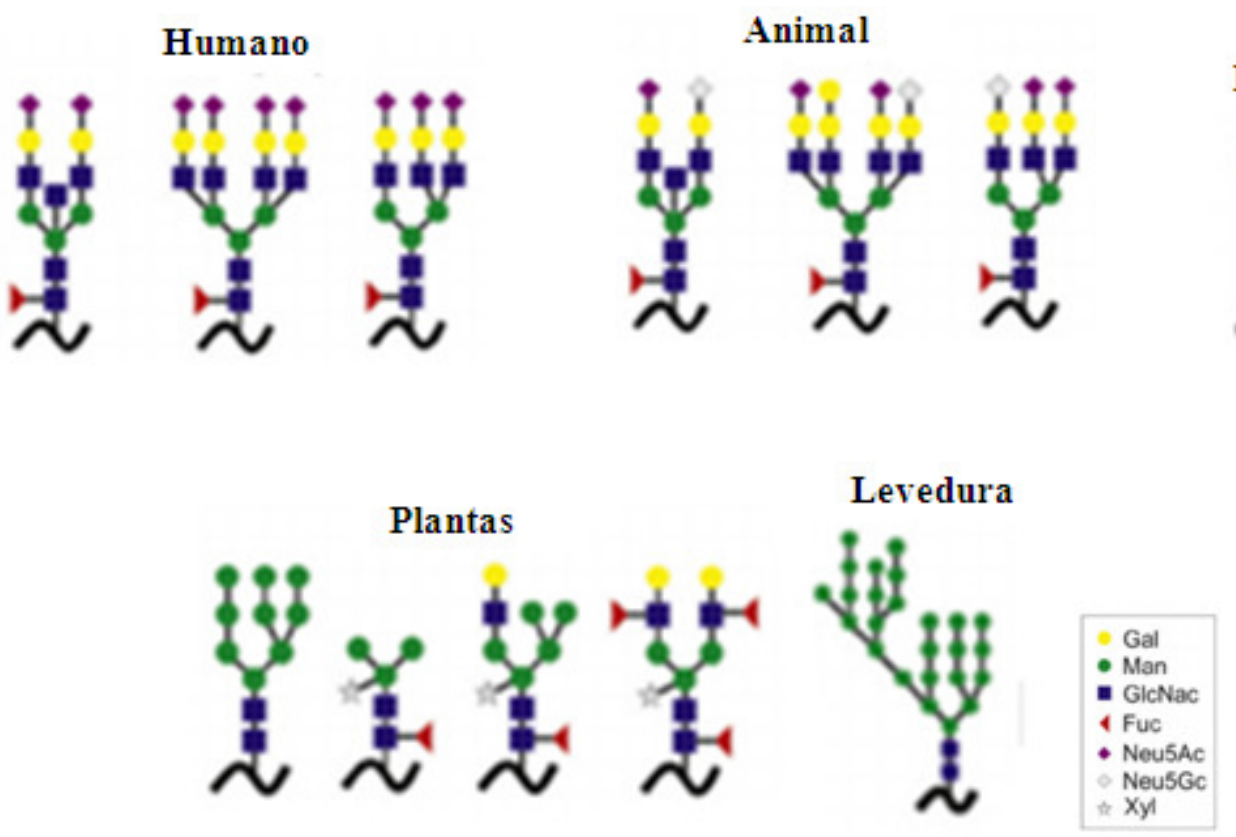

Figura 1. Desenho esquemático das estruturas típicas de glicosilação de diferentes células hospedeiras (Flieldl L e col., 2015) 
Na tentativa de aperfeiçoar os padrões de glicosilação, muitos grupos desenvolveram células de leveduras, plantas e E. coli geneticamente modificadas, criando ou modificando os seus padrões de glicosilação. No entanto, até agora os sistemas de expressão baseados em células de mamíferos são os preferidos para expressar proteínas recombinantes complexas. Atualmente, $60 \%$ dos biofármacos licenciados nos Estados Unidos e Europa são produzidos em células de mamíferos e incluem hormônios, fatores plasmáticos sanguíneos, anticoagulantes, fatores de crescimento, anticorpos, entre outros produtos (Datta P e col., 2013).

A glicosilação é a mais importante modificação pós-traducional e envolve a adição de oligossacarídeos à estrutura da proteína, que ocorre graças à ação de glicotransferases e glicosidases que adicionam o aminoácido específico à cadeia polipeptítica. Existem dois tipos de glicosilação, asparagina N-linked e serina/treonina O-linked. A glicosilação N-linked começa com um processo co-traducional no reticulo endoplasmático, onde um glicano présintetizado é adicionado ao nitrogênio da asparagina, que está ligada à cadeia polipeptídica. A glicosilação O-linked ocorre no complexo de Golgi, onde o monossacarídeo é adicionado ao oxigênio da hidroxila, que está ligado à serina ou a resíduos de treonina. A estrutura dos glicanos é subsequentemente construída pela adição individual de monossacarídeos. Além dessas duas vias principais de glicosilação, os glicanos podem ser adicionados à arginina, tirosina, hidroxilisina, hidroxiprolina e resíduos de triptofano. Essas modificações são menos comuns e são restritas à proteínas específicas (Croset A. e col., 2012).

O perfil de glicosilação de uma proteína pode ser muito heterogêneo, já que os sítios de glicosilação podem estar totalmente ocupados ou desocupados simultaneamente e, além disto, a cada sítio pode ser incorporada uma estrutura glicídica. Mecanismos potencialmente diferentes podem ser responsáveis por variações na ocupação dos sítios de glicosilação de uma glicoproteína tais como, disponibilidade do dolicol-fosfato e de nucleotídeos, atividade da glicosiltransferase e seu acesso aos sítios de glicosilação (Gawlitzek M. e col., 2009). A glicosilação afeta as interações proteína-proteína influenciando na biodisponibilidade, biodistribuição, farmacocinética e imunogenicidade do produto recombinante. Uma glicosilação imperfeita pode resultar em um produto imunogênico, farmacologicamente inativo e com depuração indesejada. A qualidade terapêutica de uma glicoproteína pode ser afetada pelo conteúdo de ácido $\mathrm{N}$-acetilneuramínico ou ácido siálico. A sialilação em geral determina a meia-vida da glicoproteína, uma vez que o ácido siálico pode impedir o seu reconhecimento pelos receptores assialoglicoproteícos presentes principalmente no fígado (Takamatsu S. e col., 
2003). Várias doenças, tais como artrite reumatoide, deficiência de adesão dos leucócitos e alguns tipos de cancer, são associadas à alterações na glicosilação (Croset A. e col., 2012).

As indústrias farmacêuticas costumam estabelecer uma linhagem celular geneticamente modificada que expressa constitutivamente a proteína recombinante, o que também é conhecido por expressão gênica estável (SGE). Este processo envolve a clonagem do gene de interesse em um vetor de expressão, que contém um marcador de seleção. As células são transfectadas com o DNA plasmidial e então ocorre a integração da sequência de DNA no genoma celular do hospedeiro. O marcador de seleção permite isolar os clones positivos, que devem ser avaliados individualmente em relação aos seus níveis de expressão. Os clones que apresentarem os maiores níveis de produção da proteína recombinante serão expandidos e estabelecidos. Este processo costuma ser trabalhoso e demorado. A expressão gênica transiente (TGE) é uma alternativa muito mais rápida para se obter um produto recombinante. A expressão do DNA ocorre de forma epissomal, por um período que varia de 2 - 15 dias (Figura 2).

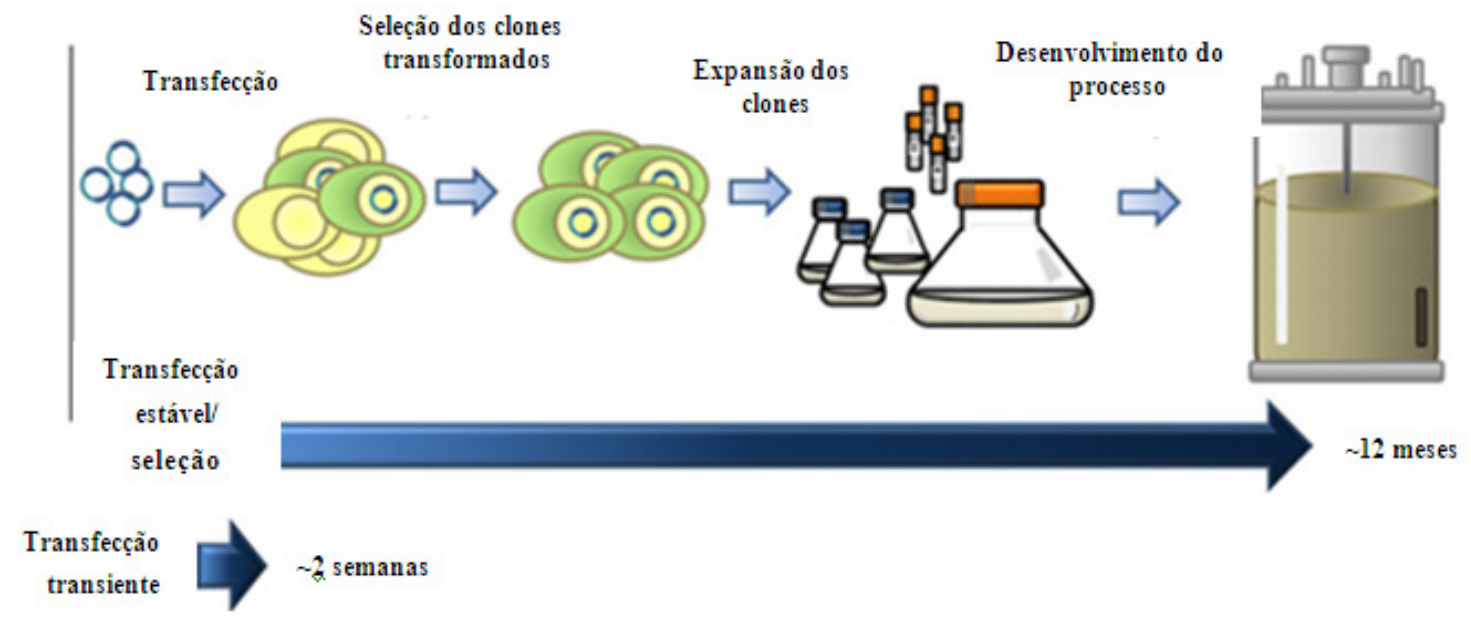

Figura 2. Desenho esquemático da produção de proteínas recombinantes através de expressão estável e expressão transiente (Bandaranayake AD, 2014).

A entrada do DNA plasmidial nas células é facilitada pelo uso de reagentes de transfecção incluindo compostos inorgânicos, como por exemplo, o fosfato de cálcio, polímeros catiônicos tal como a polietilenimina (PEI) e lipídeos catiônicos como a lipofectamina.

A célula hospedeira mais comumente usada para a SGE é a CHO (Chinese Hamster Ovary) e a linhagem celular predominante para a TGE é a HEK293 (Human Embrionic Kidney). A última tem vantagens, especialmente quando modificações pós-traducionais humanas, ao contrário daquelas observadas em células de hamster, conferem propriedades benéficas ao 
produto. Exemplo clássico disto é a proteína $\mathrm{C}$ humana ativada, com o nome comercial Xigris®, que requer modificações pós-traducionais humanas para manter sua atividade biológica. Comparadas à SGE, a TGE permite a produção rápida de biofármacos, mas o título do produto é em geral mais baixo (Geise S e col., 2009). Um dos fatores limitantes da TGE é que o DNA epissomal é perdido conforme as células se dividem. Em consequência, o tempo de produção é pequeno, o que por sua vez limita a capacidade da produção total. Várias linhagens celulares específicas foram desenvolvidas visando maximizar o tempo de produção da TGE (Swiech K e col., 2012). A mais popular é a linhagem celular HEK293T, que expressa constitutivamente o antígeno T do SV40 (simian vírus 40). Esta proteína permite a replicação de vetores contendo a origem de replicação SV40 nas células de mamíferos, portanto aumentando a persistência epissomal (Cervera L e col., 2015 a). O aumento do número de cópias de plasmídeos na população de células transfectadas é o responsável por melhorar a produção da TGE com estas células. Esta foi a linhagem celular usada no presente trabalho.

$\mathrm{Na}$ literatura são reportadas várias proteínas recombinantes expressas em diferentes linhagens de células embrionárias de rim humano, obtidas por expressão estável ou transiente (Tabela 1). 
Tabela1 Proteínas recombinantes produzidas por diferentes linhagens de células HEK. Adaptada de PicançoCastro V e col., 2013.

\begin{tabular}{|c|c|c|c|}
\hline Linhagem celular & Proteína recombinante & $\begin{array}{c}\text { Tipo de } \\
\text { expressão }\end{array}$ & Referência \\
\hline \multirow{3}{*}{ HEK293 } & Endocan & Estável & Adam E, 2008 \\
\hline & Fator VII de coagulação & Transiente & Wajih N, 2008 \\
\hline & Eritropoetina & Transiente & Zhang P, 2010 \\
\hline \multirow{2}{*}{ HEK-EBNA } & Serina/receptor de treonina quinase & Transiente & Fischer S, 2012 \\
\hline & Fragmento de laminina LG4/5 & Estável & Belin V, 2006 \\
\hline \multirow{2}{*}{ HEK293-6E EBNA1 } & Interferon humano alfa $2 \mathrm{~b}$ & Estável & $\begin{array}{l}\text { Loignon M, } \\
\quad 2008\end{array}$ \\
\hline & Eritropoetina & Transiente & Sun X, 2006 \\
\hline \multirow{2}{*}{ HEK293E } & $\operatorname{IgG}$ & Transiente & $\begin{array}{l}\text { Beckliwal G, } \\
2008\end{array}$ \\
\hline & $\begin{array}{c}\text { Fosfatase alcalina secretada pela placenta } \\
\text { humana (SEAP) }\end{array}$ & Transiente & $\begin{array}{l}\text { Pharm P. L, } \\
\quad 2005\end{array}$ \\
\hline HEK293F & Fator VIII de coagulação & Estável & $\begin{array}{l}\text { Casademunt E, } \\
2012\end{array}$ \\
\hline \multirow{2}{*}{ HEK293SF-3F6 } & BDD-Fator VIII & Transiente & Swiech K, 2012 \\
\hline & HIV-1 virus like particle & Trasiente & $\begin{array}{l}\text { Cervera, L, } \\
2015 \mathrm{~b}\end{array}$ \\
\hline HEK293H & Fator VIIFc & Transiente & $\begin{array}{l}\text { Dumont J A, } \\
\quad 2002\end{array}$ \\
\hline HEK293S & $\begin{array}{l}\text { Receptores Alfa-amino-3-hydroxy-5-methyl-4- } \\
\text { isoxozolepropionic acid (AMPA) }\end{array}$ & Transiente & Lin C, 2015 \\
\hline
\end{tabular}

A glicosilação nas células de mamíferos é específica da espécie, do órgão e do tipo celular. Em virtude das diferenças existentes entre células HEK e CHO relativas à espécie (humano e murino), ao órgão (rim e ovário) e à origem (embrionária e epitelial), são esperados diferentes perfis de glicosilação para os produtos derivados destas células, o que no caso de glicoproteínas terapêuticas é bastante critico, pois pode modular a sua eficácia. Embora muito 
utilizada, a CHO não possui a maquinaria enzimática necessária para reproduzir exatamente a glicosilação humana. Por exemplo, algumas enzimas tais como a $\alpha 2-6$ sialiltransferase, a $\alpha 1$ 3/4 fucosiltransferase e a bisecting $\mathrm{N}$-acetilglucosamina transferase estão ausentes nestas células (Durocher Y \& Buttler M, 2009). Diferentemente das células humanas, as células CHO só promovem ligação de ácido siálico-galactose na conformação $\alpha 2,3$, enquanto as células humanas promovem a sialilação também na conformação $\alpha 2,6$. Outra diferença é a ausência em humanos de ácido glicosilneuranimico (Neu5Gc), resíduo potencialmente imunogênico. Isso se deve ao fato da enzima citidina monofosfato-N-acetilneuranimico hidroxilase ácida (CMAH), responsável por converter CMP-Neu5Gc em CMP-Neu5Ac, ser inativa em células humanas devido a uma mutação. Em humanos também não há nos $\mathrm{N}$-glicanos a síntese do terminal Gal $\alpha$ 1,3 Gal, o que pode gerar a produção de anticorpos contra esta estrutura quando uma proteína recombinante gerada por linhagens celulares murinas é considerada (PicançoCastro V. e col., 2013). Reações imunogênicas podem reduzir a eficácia de um biológico em virtude da rápida depuração pelo sistema imune ou pela impossibilidade de readministração da droga, já que potencialmente pode causar resposta imune.

A expressão de proteínas recombinantes terapêuticas em sistemas de expressão baseados em células humanas gera a expectativa de produzir proteínas com modificações póstraducionais mais semelhantes às naturais, sem qualquer glicoestrutura imunogênica. Por isto sua utilização é considerada uma potencial alternativa para produção de proteínas terapêuticas para uso humano.

A tireotrofina humana (hTSH), objeto do presente trabalho, é um hormônio glicoproteico formado por duas subunidades $(\alpha$ e $\beta$ ) com 92 aminoácidos e 5 pontes disulfeto na subunidade $\alpha$ e 118 aminoácidos e 6 pontes disulfeto na subunidade $\beta$ (Ribela MTCP e col., 2006). As duas subunidades são ligadas não covalentemente e não possuem atividade biológica quando isoladas. Esse hormônio é produzido pelos tireotropos na hipófise anterior e estimula a glândula tireóide a secretar os hormônios tireoideanos, tiroxina (T4) e triiodotironina (T3), que são essenciais para regulação do metabolismo. A subunidade $\alpha$ do hTSH tem dois sítios de glicosilação N, na asparagina (Asn) 52 e Asn 78 e a subunidade $\beta$ tem um sítio de glicosilação na Asn 23. No hTSH pituitário, os N-glicanos complexos são predominantemente terminados em $\mathrm{N}$-acetilgalactosamina (GalNac) sulfatada em adição a uma pequena quantidade de ácido siálico, em virtude da expressão de GalNAc-transferase e sulfotransferase nos tireotropos pituitários (Green ED \& Baenziger JU, 1988). Entretanto, o hTSH recombinante produzido em células $\mathrm{CHO}$ é apenas sialilado, pois nas células $\mathrm{CHO}$ está ausente a sulfotransferase, enzima responsável pela sulfatação do carboidrato $\mathrm{N}$-acetilgalactosamina. Em consequência, uma das 
terminações mais comuns das glicoproteínas humanas de origem hipofisária, o sulfato, não existe nos produtos derivados de células $\mathrm{CHO}$.

Vários estudos na literatura mostram que a maior sialilação do hTSH recombinante produzido em células $\mathrm{CHO}$ resulta em uma maior atividade biológica in vivo e uma meia-vida plasmática maior, provavelmente causada pela menor depuração através do receptor hepático manose/GalNac-sulfato e/ou pelo receptor assialoglicoproteico (Simpson DZ e col., 1999, Szkudlinki MW e col., 1993 e 1995).

O hTSH recombinante apresenta várias aplicações no campo diagnóstico e terapêutico e tem sido utilizado para avaliar a função tireoidiana, no tratamento do bócio multinodular e no diagnóstico e tratamento do câncer de tireóide. O único produto recombinante existente no mercado é derivado de células CHO (Thyrogen ${ }^{\circledR}$ ), tendo sido sua utilização na detecção e tratamento de câncer de tireóide aprovada pelo FDA (Food and Drug Admnistration) em 1998 (Szkudlinki MW e col., 2002).

Vários estudos relacionados ao hTSH já foram desenvolvidos em nosso laboratório relativos à síntese em células $\mathrm{CHO}$ do hTSH recombinante IPEN (Peroni CN e col., 2002; Ribela MTCP e col., 2003), à sua purificação e caracterização (Oliveira JE e col., 2003; Mendonça F e col., 2005; Ribela MTCP e col., 2006; Oliveira JE e col., 2007; Carvalho CM e col., 2009; Almeida BE e col., 2014; Silva MA e col., 2016) e à influência de condições de cultivo de células CHO produtoras de hTSH na síntese deste hormônio (Oliveira JE e col., 2008; Damiani R e col., 2013). Uma outra forma de hTSH produzida em CHO com configuração de oligossacarídeos mais parecida àquela do produto humano de extração hipofisária (hTSH recombinante humanizado, hlsr-hTSH), foi também sintetizada em nosso laboratório (Damiani R e col., 2009).

$\mathrm{Na}$ literatura não há relatos de tireotrofina recombinante expressa em células humanas. Tendo em vista o cenário apresentado anteriormente, a nosso ver é extremamente importante identificar o impacto farmacológico relacionado ao sistema de expressão e trabalhar para obter glicoproteínas recombinantes cada vez mais similares às naturais. 


\section{OBJETIVO}

Sintetizar a tireotrofina humana em células embrionárias de rim humano (HEK293) e compará-la à preparação recombinante derivada de células $\mathrm{CHO}$ e à preparação nativa, derivada da hipófise.

\subsection{Objetivos específicos}

- Clonar os genes das subunidades $\alpha$ e $\beta$ do hTSH nos vetores de expressão.

- Sequenciar os vetores e confirmar a orientação dos genes.

- Cultivar e trasnfectar as células HEK293 com os vetores de expressão

- Purificar o hTSH do meio condicionado e caracterizá-lo quanto à massa molecular, composição de carboidratos, atividade biológica e farmacocinética.

- Comparar o hTSH obtido no presente trabalho ao hTSH já produzido em células CHO e ao hTSH pituitário. 


\section{MATERIAL E MÉTODOS}

\subsection{MATERIAL}

\subsubsection{Reação de polimerase em cadeia (PCR)}

- Agarose, Uniscience (São Paulo, SP, Brasil).

- Brometo de etídio, Uniscience (São Paulo, SP, Brasil).

- Enzima Taq polimerase platinum HiFi, Life Techonology (Carlsbald, CA, USA)

- Primers sense e anti-sense das subunidades $\alpha$ e $\beta$ do hTSH, Exxtend (Campinas, São Paulo, Brasil).

- Primers para o sequenciamento do vetor: CMV forward e pcDNA ${ }^{\mathrm{TM}} 3.4$ reverse, Life Techonology (Carlsbald, CA, USA).

- Genes da subunidade $\alpha$ e $\beta$ do hTSH previamente clonados nos vetores pEDdc- $\alpha$ e pEAdc- $\beta$ (Peroni CN e col., 2002).

- Tris HCl, Sinth (São Paulo, SP, Brasil).

- Acetato de sódio, Sinth (São Paulo, SP, Brasil).

- $\quad$ EDTA, Sinth (São Paulo, SP, Brasil).

\subsubsection{Vetor de expressão}

- Vetor comercial de expressão pcDNA 3.4 TOPO, Life Techonology (Carlsbald, CA, USA)

\subsubsection{Transformação de células competentes}

\subsubsection{Linhagem celular}

- E.coli DH5a quimicamente competentes One Shot ${ }^{\circledR}$ TOP10, Life Technologies (Carlsbald, CA, USA)

\subsubsection{Meio de cultura}

- Meio S.O.C, , Life Techonology (Carlsbald, CA, USA)

- LB Agar, Sinth (São Paulo, SP, Brasil) 


\subsubsection{Antibiótico}

- Ampicilina, Vitrocell Embriolife (Campinas, SP, Brasil).

\subsubsection{Kits de extração e purificação de DNA plasmidial}

- NucleoBond® (Macherey-Nagel, Düren, Alemanha.

\subsubsection{Transfecção}

\subsubsection{Reagentes}

- Expifectamina. Life Technology (Carlsbald, CA, USA).

\subsubsection{Linhagem cellular}

- Células HEK293T que expressa constitutivamente o antígeno T do SV40 (Simian vírus 40).

\subsubsection{Preparações hormonais utilizadas}

- hTSH de origem hipofisária (hTSH-Pit), produzido e fornecido pelo Dr. Peter A. Torjesen do “Aker University Hospital” (Oslo, Noruega).

- hTSH derivado de células de ovário de Hamster Chinês (hTSH-CHO) (Thyrogen®), produzido por "Genzyme Corporation" (Cambridge, EUA) e fornecido pela Collect (São Paulo, SP, Brazil).

\subsubsection{Cultivo celular}

\subsubsection{Reagentes utilizados nos procedimentos de cultura celular}

- Bicarbonato de sódio P.A., Sinth (São Paulo, Brasil)

- Dimetilssulfóxido (DMSO), MERK (São Paulo, Brasil).

- Meio DMEM, Gibco-BRL (Gaithersburg, MD, EUA).

- Soro fetal bovino dialisado (SFBd), Gibco-BRL (Gaithersburg, MD, EUA).

- Tripsina, Gibco-BRL (Gaithersburg, MD, EUA). 


\subsubsection{Material plástico estéril}

- Garrafas de $75 \mathrm{~cm} 2$, Corning Costar (NY, EUA).

- Pipetas de 2, 5, 10 e $25 \mathrm{~mL}$, Corning Costar (NY, EUA).

- Sistema de filtração de $500 \mathrm{~mL}, 0,22 \mu \mathrm{m}$, Corning Costar (NY, EUA).

- Tubos criogênicos de $2 \mathrm{~mL}$, Corning Costar (NY, EUA).

- Tubos para centrífuga de 15 e 50 mL, Corning Costar (NY, EUA).

\subsubsection{Purificação e análise do hTSH}

\subsubsection{Colunas cromatográficas}

\section{a) Coluna de vidro utilizada em cromatografia clássica}

- Coluna XK (20cm X 16mm DI), GE Healthcare (Buckinghamshire, Inglaterra).

\section{b) Colunas cromatográficas utilizadas na cromatografia líquida de alta eficiência (HPLC)}

- Coluna TSK G 2000 SW (60 cm X 7,5 mm D.I.), acoplada a uma pré-coluna SW (7,5 cm x 7,5 mm DI), Tosohaas (Montgomeryville, PA, EUA), para HPLC de exclusão molecular.

- Coluna C4, 214 TP54 (25 cm X 4,6 mm D.I.), acoplada à pré-coluna 214 FSK 54 (5 m, 1,0cm X 4,6 mm D.I.), Vydac Separations Group (Hesperia, CA, EUA), para HPLC de fase reversa analítica.

- Coluna C4, 214 TP510 (25 cm X 10 mm D.I.), acoplada à pré-coluna 214 FSK 54 (5 ㅆm, 1,0cm X 4,6 mm D.I.), Vydac Separations Group (Hesperia, CA, EUA), para HPLC de fase reversa semi-preparativa.

\subsubsection{Resinas cromatográficas}

- Resina cromatográfica SP Sepharose Fast Flow (SPFF), GE Healthcare (Buckinghamshire, Inglaterra), para cromatografia clássica.

- Sílica gel, grupo funcional Diol, tamanho das partículas $10 \mu \mathrm{m}$ e poros de $125 \AA$, Tosohaas (Montgomeryville, PA, EUA), para HPLC de exclusão molecular.

- Sílica com grupos de ligação butil alifático, tamanho das partículas $5 \mu \mathrm{m}$ e diâmetro dos poros de $300 \AA ̊$, Vydac Separations Group (Hesperia, CA, EUA) para HPLC de fase reversa. 


\subsubsection{Reagentes químicos}

- Acetonitrila grau HPLC, Mallinckrodt (Phillipsburg, EUA).

- Acetato de sódio, Merck (São Paulo, Brasil).

- Ácido acético, Labsynth (São Paulo, Brasil).

- Cloreto de sódio p.a., Merck (São Paulo, Brasil).

- Fosfato de sódio monobásico p.a., Merck (São Paulo, Brasil).

- Fosfato de sódio bibásico p.a., Merck (São Paulo, Brasil).

- Metanol, grau HPLC, Mallinckrodt (Phillipsburg, EUA).

\subsubsection{Imunoensaios}

\subsubsection{Anticorpos}

- Anticorpo monoclonal (mAB) anti hTSH (anticorpo de detecção utilizado no radioensaio), fornecido pelo Netria, North East Thames Region Immunoassay Unit (Londres, Inglaterra).

- Anticorpo policlonal anti hTSH acoplado a celulose (anticorpo de captura, fase sólida), fornecido pelo Netria, North East Thames Region Immunoassay Unit (Londres, Inglaterra).

\subsubsection{Reagentes para marcação do anticorpo de detecção}

- Cloramina T P. A., Merck (São Paulo, Brasil).

- Iodeto de potássio p.a., Merck (São Paulo, Brasil).

- Metabissulfito de sódio, Carlo Erba (São Paulo, Brasil).

- $\quad \mathrm{NaI}^{125}$ comercial livre de carregadores e oxidantes, com atividade específica de 11100-22200 $\mathrm{MBq} / \mathrm{mL}$ (300-600 mCi/mL), Nordion Europe S.A. (Fleurus, Bélgica).

\subsubsection{Outros reagentes}

- Soro albumina bovina (BSA) RIA Grade (fração V), Sigma (St. Louis, EUA).

- Tween 20, Sigma (St. Louis, EUA).

\subsubsection{Ensaio biológico}

- Camundongos machos da linhagem isogênica Balb-C, com peso de 22 - 30g, oriundos do Biotério de Criação e Manutenção de Animais de Laboratório do IPEN/CNEN - SP. 
- Sal de sódio de 3,3',5-triiodo-L-tironina (T3), Sigma (St. Louis, MO, EUA).

- Kit de ELISA para dosagem de tiroxina total (T4), Foresight (San Diego, CA, USA).

\subsubsection{Proteína total}

- Kit micro BCA, Pierce (Rockford, EUA).

- Placas de microtitulação com fundo em “U”, Dynatech (Chantilly, EUA).

\subsubsection{Equipamentos e acessórios principais}

- Agitador magnético modelo 258, Fanem (São Paulo, Brasil).

- Agitador rotatório de tubos ("rotator"), fornecido pelo laboratório NETRIA, North East Thames Region Immunoassay Unit (Londres, Inglaterra).

- Agitador rotatório tipo vortex, modelo 162, Marconi (São Paulo, Brasil).

- Aparelho de cromatografia líquida de alta eficiência (HPLC), modelo SCL- 10A, acoplado a um detector de UV SPD-10AV e a um programa de computador Class VP, Shimadzu (MD, EUA).

- Autoclave vertical, modelo 103, Fabbe-Primar (São Paulo, Brasil).

- Balança analítica, modelo H20T, Mettler (Zurich, Suíça).

- Balança analítica, modelo P100N, Mettler (Zurich, Suíça).

- Balança analítica, modelo M5AS, Mettler (Zurich, Suíça).

- Bomba peristáltica modelo P-1, GE Healthcare (Buckinghamshire, Inglaterra).

- Câmera de Neubauer, Boeco (Hamburg, Alemanha).

- Cassete para diálise Slide-A-Lyzer dialysis, 3,5 kDa de "cut off”, Pierce (Illinois, EUA).

- Centrífuga, modelo LS-3 plus, Celm (São Paulo, Brasil).

- Centrífuga refrigerada automática modelo Super Speed RC - 2B, Sorvall (Newtown, Connecticut, EUA).

- Contador gama Wizard 2470-0010 tipo "poço", com troca automática de amostra, Perkin Elmer (Illinois, EUA).

- Estufa de cultura celular, modelo 3159, Forma Scientific (Marietta, Ohio, EUA).

- Fluxo Laminar classe II A/B 3, modelo 1140, Forma Scientific (Marietta, Ohio, EUA).

- Fonte de alta tensão para eletroforese ECPS 3000/150, GE Healthcare (Buckinghamshire, Inglaterra).

- Fonte de alta tensão para eletroforese EPS 600, GE Healthcare (Buckinghamshire, Inglaterra).

- Fotodocumentador, modelo Minibis Pro, DNR Image systems, (Jerusalém, Israel). 
- Freezer $-20^{\circ} \mathrm{C}$, modelo 0651, Prosdócimo (São Paulo, Brasil).

- Freezer $-80^{\circ} \mathrm{C}$, modelo 8425 , Forma Scientific (Marietta, Ohio, EUA).

- Leitor de placas modelo Multiskan Ex (Thermo Electron Corporation, EUA)

- Liofilizador, modelo XL SP-Scientific (Ipswich, Inglaterra).

- Medidor digital de pH, modelo 420A, Orion (Boston, MA, EUA).

- Membranas de filtração de 0,22 $\mu \mathrm{m}$, Millipore (Bedford, MA, EUA).

- Microscópio invertido, modelo ID 03, Carl Zeiss (Oberkochen, Alemanha).

- Mini-centrifuga, modelo 541HP, Eppendorf (Hamburgo, Alemanha).

- Nanodrop ${ }^{T M} 1000$ (Thermo Fisher Scientific, Wilmington, DE, USA).

- Refrigerador com porta de vidro modelo VE 730, Metalfrio (São Paulo, Brasil).

- Sistema de purificação de água Milli-Q plus, Millipore (Bedford, EUA).

- Sistema de purificação AKTA Purifier, GE Healthcare (Uppsala, Suécia).

- Termociclador Verti 96-well Applied Biosystems®, (Foster City, CA, EUA)

- Tubos de poliestireno para imunoensaios (7,5x1,2 cm), EMTEL (São Paulo, Brasil). 


\subsection{MÉTODOS}

\subsubsection{Obtenção da região codificadora das subunidades $\alpha$ e $\beta$ do TSH humano}

Os genes das subunidades $\alpha$ e $\beta$ já existentes no nosso laboratório (pEDdc- $\alpha$ e pEAdc$\beta$ ) e utilizados na síntese do hTSH em células CHO (Peroni CN. e col. 2002; Damiani R. e col. 2009) foram amplificados por Reação de Polimerase em Cadeia (PCR). Utilizaram-se os primers sense e anti-sense específicos de cada subunidade na concentração de $10 \mathrm{mM}$ e $1 \mathrm{U}$ de Taq DNA polimerase de alta fidelidade. A reação foi realizada no termociclador seguindo as condições abaixo (Tabela 2).

Tabela 2. Condições utilizadas no PCR

\begin{tabular}{cccc}
\hline & Temperatura & Tempo & Número de ciclos \\
\hline Denaturação incial & $95^{\circ} \mathrm{C}$ & $3{ }^{\prime}$ & 1 \\
Denaturação & $95^{\circ} \mathrm{C}$ & $30{ }^{\prime}$ & \\
Anelamento & $55^{\circ} \mathrm{C}$ & $30^{\prime}$ & 35 \\
Extensão & $72^{\circ} \mathrm{C}$ & 1, & 1 \\
Extensão final & $72^{\circ} \mathrm{C}$ & $10^{\prime}$ & \\
\hline
\end{tabular}

Realizou-se um ciclo de extensão final para garantir a poliadenilação das extremidades 3'.

\subsubsection{Purificação do produto de PCR}

O material obtido no item 3.2.1 foi analisado por eletroforese em gel de agarose 1,2\%. A agarose foi dissolvida com leve aquecimento em tampão TAE 1x (Tris-Acetato-EDTA) e acrescida de $1,0 \mu \mathrm{L}$ de uma solução de brometo de etídio $(1 \mathrm{mg} / \mathrm{mL})$ para posterior visualização das bandas. A solução foi despejada em um molde até sua completa polimerização e em seguida posicionada na cuba de eletroforese. As amostras foram aplicadas na seguinte sequência: (1) marcador de peso molecular de 100 pb, (2) reação de amplificação da subunidade $\alpha$ e (3) reação de amplificação da subunidade $\beta$. Aplicou-se uma tensão elétrica de 80 volts durante 60 minutos. Após esse período, o gel foi visualizado em luz ultravioleta e as bandas correspondentes ao inserto amplificado foram recortadas e purificadas com o kit de purificação. Devido ao baixo rendimento do processo, as amostras foram reamplificadas de acordo com as condições anteriormente citadas. 


\subsubsection{Clonagem das subunidades no vetor de expressão}

Foi utilizado o vetor de expressão pcDNA 3.4 TOPO que contem alguns elementos que favorecem o aumento da expressão gênica, tais como a presença do promotor CMV humano e do elemento regulador pós-transcricional de Woodchuck (WPRE) (Almo SC \& Love JD, 2014). A ligação do inserto é intermediada pela ação da enzima topoisomerase I, que se encontra ligada covalentemente ao vetor. Na sua forma linearizada, o pcDNA 3.4 TOPO apresenta um resíduo de deoxitimina (T) na extremidade 3' (Figura 3).

A topoisomerase I se liga ao DNA dupla fita em sítios específicos e cliva a ligação fosfodiester depois da sequência 5'-CCCTT em uma das fitas. A energia da quebra da ligação é conservada para a formação de uma ligação covalente entre o grupo fosfato do grupo 3' da fita clivada e o resíduo tirosil (Tyr-274) da topoisomerase I. Na sequência, a ligação fosfotirosil entre o DNA e a enzima é atacada pelo grupo 5' hidroxil da fita que foi clivada, revertendo a ligação e liberando a topoisomerase (Schuman S, 1994).

À $1,0 \mu \mathrm{L}$ do vetor foi adicionado $100 \mathrm{ng}$ do produto de PCR purificado. A reação foi agitada suavemente e incubada por 5 minutos, a temperatura ambiente. A reação foi conservada em gelo. Em seguida foi realizada a transformação das células competentes.

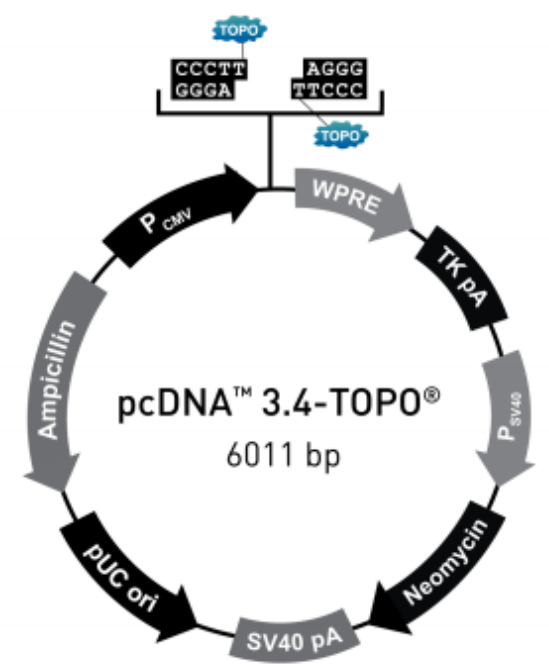

Figura 3. Esquema geral do vetor pcDNA TOPO 3.4: (1) Promotor CMV [P $\mathrm{CMV}_{\mathrm{CMV}}$ : 47 -726; (2) Sítio CMV para ligação do primer sense: 584 - 604; (3) Sítio de clonagem do vetor: 741; (3) WPRE (Woodchuck posttranscriptional regulatory element): 782; (4) pcDNA 3.4 sítio de ligação do primer anti-sense: 822-844; (5) Sinal de poliadenilação TK [TK pA]: 1388-1655; SV40 "early promoter" [ $\left.\mathrm{P}_{\mathrm{sv} 40}\right]$ : 2124-2493; (6) Gene de resistência a neomicina (marcador de seleção): 2529-3323; (7) Sítio de poliadenilação [SV40 pA]: 34499-3629; (8) pUC origin para um alto número de cópias e manutenção do plasmideo na E.coli: 4012-4685; (9) Gene de resistência a ampicilina (marcador de seleção): 4830-5640. 


\subsubsection{Transformação das células competentes pelo método do choque térmico}

Adicionou-se 2,0 $\mu \mathrm{L}$ da reação de clonagem (item 3.2.3) às células E.coli DH5a. As células com o plasmídio foram suavemente agitadas e incubadas no gelo, por 15 minutos. Após o período de incubação, realizou-se o choque térmico em banho maria $\left(42^{\circ} \mathrm{C}\right.$, por 30 segundos). A reação foi imediatamente transferida para o gelo, e adicionou-se $250 \mu \mathrm{L}$ de meio S.O.C (“super optimal broth") a cada tubo.

As amostras foram novamente incubadas $\left(1 \mathrm{~h}, 37^{\circ} \mathrm{C}, 150 \mathrm{rpm}\right)$. Semeou-se $10 \mu \mathrm{L}$ de cada reação em meio LB ágar com $0,1 \mathrm{mg} / \mathrm{mL}$ de ampicilina. As amostras foram incubadas overnight, a $37^{\circ} \mathrm{C}$.

\subsubsection{Seleção dos clones positivos}

Após o período de incubação realizou-se triagem dos clones positivos por PCR. O material obtido foi analisado em eletroforese em gel de agarose, conforme o item 3.2.2. Em seguida, realizou-se uma miniprepração plasmidial dos clones positivos. A quantificação e a pureza (razão 260/280nm) do material foram determinadas através de espectrofotometria, utilizando o equipamento Nanodrop ${ }^{T M}$. Em seguida as amostras foram enviadas para sequenciamento.

\subsubsection{Sequenciamento das amostras}

A confirmação da orientação do inserto foi realizada por sequenciamento. Foram preparadas alíquotas no volume total de $7,5 \mu \mathrm{L}$ contendo $775 \mathrm{ng}$ de cDNA da subunidade $\alpha$ e $800 \mathrm{ng}$ de cDNA da subunidade $\beta$ acrescidos dos primers do vetor (5 pmoles $/ \mu \mathrm{L}$ ). O sequenciamento foi realizado no Centro de Estudos do Genoma Humano (CEGH), em sequenciador ABI 3730 DNA Analyser (Life Technologies - Applied Biosystems) e analisado pelo software BioEdit.

\subsubsection{Transfecção}

Células da linhagem HEK293T, que expressa o gene "SV40 large T antigen", foram transfectadas pelo método da lipofectamina, lipídeo catiônico que facilita a entrada do DNA nas células. Foi utilizado DNA na proporção de 1:5 das subunidades $\alpha$ e $\beta$ (Peroni CN. e col., 2002). As células ( $3 \times 10^{6} \mathrm{cel} / 10 \mathrm{~mL}$ ) foram semeadas em uma placa de $75 \mathrm{~cm}^{2}$ no dia anterior 
à transfecção e mantidas com meio Dulbecco's Modified Medium, suplementado com 10\% de soro fetal bovino. No dia da transfecção, o DNA $(16 \mu \mathrm{g})$ foi diluído em $50 \mu \mathrm{L}$ de meio DMEM sem soro e sem antibiótico. Separadamente realizou-se a diluição de $16 \mu \mathrm{L}$ de expifectamina em $50 \mu \mathrm{L}$ do mesmo diluente. Esta solução foi incubada por 5 minutos, a temperatura ambiente. Após esse período, o DNA diluído foi adicionado à expifectamina diluída perfazendo o total de $100 \mu \mathrm{L}$. Esta solução foi incubada por 30 minutos, a temperatura ambiente. Após o período de incubação, o meio de cultura das células foi removido e substituído por $5 \mathrm{~mL}$ de meio fresco sem soro e sem antibiótico. Em seguida, adicionou-se às células os $100 \mu \mathrm{L}$ do complexo formado. As células foram incubadas por um período de $5 \mathrm{~h}$ a $37{ }^{\circ} \mathrm{C}$ com $5 \%$ de $\mathrm{CO}_{2}$. Em seguida adicionou-se $5 \mathrm{~mL}$ de DMEM com $20 \%$ de soro. Após a transfecção, as células foram mantidas em cultura por um período de 5 dias. O meio de cultura foi coletado e substituído diariamente por $10 \mathrm{~mL}$ de DMEM sem soro e armazenado a $-20^{\circ} \mathrm{C}$ para posterior análise.

\subsubsection{Processo de Purificação}

O processo de purificação empregado neste trabalho seguiu um protocolo previamente padronizado em nosso laboratório (Oliveira JE e col., 2007). O processo consiste de duas etapas cromatográficas, sendo a primeira uma cromatografia clássica de troca iônica, do tipo catiônica, seguida de uma cromatografia líquida de alta eficiência de fase reversa.

\subsubsection{Cromatografia de troca iônica}

Em uma purificação típica, o meio condicionado, após ter seu pH acertado para 5,0, foi aplicado a uma coluna de 2,6 cm de diâmetro x $10 \mathrm{~cm}$ de altura, contendo a resina SP Sepharose Fast Flow (SPFF) (resina de troca catiônica), previamente equilibrada em 0,02M de acetato de sódio, pH 5,0 com 0,05M de NaCl. Após lavagens sucessivas (cinco volumes de coluna no mínimo) com este mesmo tampão, as proteínas foram eluídas neste mesmo tampão com um gradiente linear de $\mathrm{NaCl}(0,05 \mathrm{M}$ a $0,25 \mathrm{M})$. O fluxo utilizado foi de $200 \mathrm{~mL} / \mathrm{h}$ e as frações coletadas foram de $5 \mathrm{~mL}$. 


\subsubsection{Cromatografia líquida de alta eficiência em fase reversa preparativa (RP-HPLC)}

O pool das frações contendo hTSH, detectado por IRMA, resultante da primeira etapa de purificação, foi concentrado para $10 \mathrm{~mL}$ em um dispositivo filtrante de centrífuga Amicon Ultra-15 e aplicado a uma coluna $\mathrm{C} 4$ semi preparativa de fase reversa. A coluna, conectada a um HPLC, foi mantida a $25^{\circ} \mathrm{C}$ e foram usados na fase móvel dois tampões A e B (tampão A: fosfato de sódio 0,05M pH 7,0 e tampão B: 50\% de A + 50\% de acetonitrila). A eluição das proteínas foi realizada com um gradiente linear de 25 a 100\% de tampão B, durante 40 minutos. Um fluxo de trabalho de $2,5 \mathrm{~mL} / \mathrm{min}$ e detecção por luz ultravioleta (UV) no comprimento de onda de $220 \mathrm{~nm}$ foram utilizados. O pool final foi dialisado contra tampão fosfato de sódio 0,02M, pH 7,0, contendo 0,15M NaCl. Após a diálise, o hTSH foi liofilizado sob vácuo controlado entre 100-200 mT na fase primária e sob vácuo máximo na fase secundária para retirada da umidade residual.

\subsection{Cromatografia líquida de alta eficiência analítica}

A análise quantitativa e qualitativa do hTSH presente no meio condicionado e nas diferentes etapas do processo de purificação foi realizada mediante cromatografia líquida de alta eficiência de fase reversa (RP-HPLC) e de exclusão molecular (HPSEC), de acordo com as condições experimentais das Tabelas 3 e 4.

Tabela 3. Condições experimentais da RP-HPLC

\begin{tabular}{ll}
\hline Coluna & Vydac C4 \\
Fase móvel & $\begin{array}{l}\text { Tampão A: Fosfato de sódio 0,05M pH7,0 } \\
\text { Tampão B: 50\% acetonitrila + 50\% tampão A }\end{array}$ \\
$\begin{array}{l}\text { Tempo de corrida } \\
\begin{array}{l}\text { Fluxo } \\
\text { Eluição }\end{array}\end{array}$ & $\begin{array}{l}0,5 \mathrm{~mL} / \text { minutos } \\
\text { Gradiente linear de } 25 \text { a } 100 \% \text { B }\end{array}$ \\
$\begin{array}{l}\text { Detecção } \\
\begin{array}{l}\text { Temperatura da } \\
\text { coluna }\end{array}\end{array}$ & $220 \mathrm{~nm}$ \\
\hline
\end{tabular}


Tabela 4. Condições experimentais da HPSEC

$\begin{array}{ll}\text { Coluna } & \text { TosoHaas TSK } 2000 \\ \text { Fase móvel } & \text { Tampão fosfato de sódio } 0,02 \mathrm{M} \mathrm{pH} \mathrm{7,0+0,15 \%} \mathrm{NaCl} \\ \text { Tempo de corrida } & 40 \text { minutos } \\ \text { Fluxo } & 1,0 \mathrm{~mL} / \text { minuto } \\ \text { Eluição } & \text { Isocrática } \\ \text { Detecção } & 220 \mathrm{~nm} \\ \text { Temperatura da coluna } & 25^{\circ} \mathrm{C}\end{array}$

A preparação recombinante comercial Thyrogen ${ }^{\circledR}$ foi utilizada como preparação referência nas duas técnicas de análise.

\subsubsection{Ensaio imunoradiométrico (IRMA)}

Os níveis de hTSH foram determinados por IRMA desenvolvido em nosso laboratório (Ribela MTCP e col., 1996). No ensaio foi realizada uma curva padrão de TSH (Thyrogen®), com níveis de concentração distintos $(0,15 ; 0,3 ; 0,6 ; 1,5 ; 3,0 ; 7,5 ; 15 ; 30 ; 60 ; 100 \mu \mathrm{UL} / \mathrm{mL})$. Pipetaram-se duplicatas de $100 \mu \mathrm{L}$ de cada ponto da curva a um tubo de ensaio contendo 300

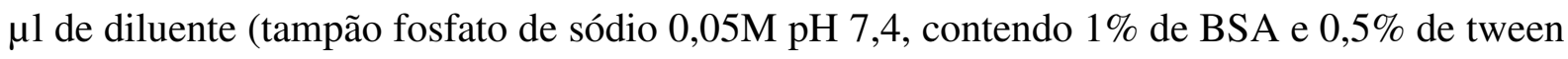
20). Pipetaram-se, em duplicata, $100 \mu \mathrm{L}$ das amostras provenientes de cada dia de expressão (24h, 48h, 72h, 96h e 120h). Em seguida adicionou-se $50 \mu \mathrm{L} \mathrm{de} \mathrm{I}^{125}$ - mAB anti-hTSH contendo aproximadamente $60000 \mathrm{cpm}$ e $50 \mu \mathrm{L}$ de fase sólida (celulose que contem anticorpo anti hTSH ligado à sua superfície). O ensaio foi incubado overnight em um agitador rotatório de tubos. Após a incubação, foram adicionados $2 \mathrm{~mL}$ de tampão de lavagem (tampão fosfato $0,05 \mathrm{M}, \mathrm{pH}$ $7,4+0,5 \%$ de Tween 20) a cada tudo e a separação da fase sólida foi realizada por centrifugação a $6000 \mathrm{~g}$, por 30 minutos, a $4^{\circ} \mathrm{C}$. Esse processo foi realizado 2 vezes.

\subsubsection{Determinação de proteína total}

A concentração de proteína total das amostras resultantes de cada etapa do processo de purificação foi determinada pelo método Micro BCA, que consiste na detecção e quantificação colorimétrica da proteína total diluída em solução após a reação com o ácido bicinconínico (BCA). Foi realizada uma curva padrão de BSA (albumina de soro bovino) com níveis de concentração distintos $(40,20,10,5,2,5,1,0$ e $0,5 \mu \mathrm{g} / \mathrm{mL})$. No caso do meio condicionado, a amostra foi dialisada contra água, em um tubo Amicon Ultra de $4 \mathrm{~mL}$ (Millipore) com uma membrana de $3000 \mathrm{kDa}$, centrifugada a 4000g, por 30 minutos. As centrifugações e a adição 
de diluente foram realizadas até que o produto final fosse totalmente incolor. Pipetou-se em duplicata $125 \mu \mathrm{L}$ das preparações de padrão e amostras em poços de uma placa de ELISA. Em seguida, adicionou-se $125 \mu \mathrm{L}$ do reagente de trabalho composto por: $50 \%$ da solução A (carbonato de sódio, bicarbonato de sódio, tartarato de sódio e hidróxido de sódio), $48 \%$ da solução B (solução aquosa de ácido bicinconínico 4\%) e $2 \%$ da solução C (sulfato cúprico penta-hidratado $4 \%$ ). A placa foi incubada por $1 \mathrm{~h}$, a $37^{\circ} \mathrm{C}$. A absorbância foi determinada a 540 $\mathrm{nm}$ em leitor de placa.

\subsubsection{SDS-PAGE}

As diferentes etapas de purificação do hTSH-HEK e as preparações de referência hTSH$\mathrm{CHO}$ e hTSH-Pit foram analisadas por eletroforese em gel de poliacrilamida 15\%, na presença de $0,1 \%$ de dodecil sulfato de sódio (SDS-PAGE) sob condições não redutoras. As amostras a serem analisadas foram adicionadas ao tampão de amostra, que consiste de $2 \mathrm{~mL}$ de glicerol 20\%, $3 \mathrm{~mL}$ de SDS 20\%, $10 \mathrm{mg}$ de azul de bromofenol (0,1\%), 2,5 mL de Tris-HCL pH 6,8 e água Milli-Q, na proporção de 3:1 (tampão:amostra) e aplicadas após serem submetidas a fervura por 15 minutos. Durante a corrida eletroforética, a intensidade da corrente foi de 35 mA. As proteínas presentes no gel foram fixadas mergulhando o gel em uma solução com $40 \%$ de metanol e $10 \%$ de ácido acético glacial, por 30 minutos. Após a fixação o gel é submetido a 3 ciclos de lavagem alternando-se água destilada e deionizada com 50\% de metanol, sob agitação, durante 5 - 10 minutos para cada lavagem. O gel é em seguida incubado por 15 minutos, sob agitação, em solução de nitrato de prata (nitrato de prata $0,8 \%, \mathrm{NaOH} 0,2 \mathrm{~N}$, $\mathrm{NH}_{4} \mathrm{OH} 0,2 \mathrm{~N}$ ) recém preparada. Ao final da incubação, o gel é novamente lavado 2 vezes com água destilada e deionizada e, em seguida, mergulhado em solução reveladora $(0,005 \%$ ácido cítrico, $0,05 \%$ formaldeído) recém preparada. A partir desse momento a agitação passa a ser manual, observando-se cuidadosamente as bandas que devem surgir gradativamente (6-8 minutos). Para cessar a reação o gel é mergulhado na solução fixadora. Após a revelação, o gel é lavado com solução $50 \%$ metanol, $10 \%$ ácido acético e conservada em solução $40 \%$ de metanol, $10 \%$ glicerol. 


\subsubsection{Atividade biológica}

A avaliação da atividade biológica das preparações de hTSH-HEK, hTSH-CHO e hTSH-Pit foi realizada por um ensaio in vivo, utilizando camundongos machos da linhagem isogênica BALB/c, com peso variando entre 22-30g. O ensaio baseia-se na capacidade do TSH em estimular a produção de T4. Visando suprimir o TSH endógeno dos animais, foi administrada oralmente, durante 3 dias, triiodotironina (T3), $\mathrm{pH}$ 7,5, com uma concentração final de $3 \mu \mathrm{g} / \mathrm{mL}$. Após a supressão do TSH endógeno, as amostras a serem analisadas foram

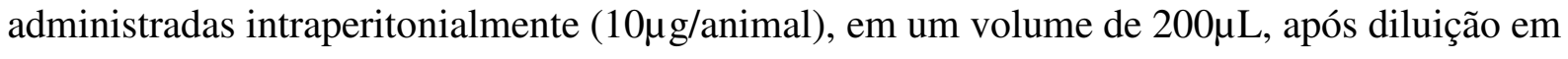
solução salina. Para cada preparação foram utilizados 10 animais, bem como para o controle (salina). Após 6 horas da administração das amostras foi realizada a coleta de sangue, via plexo retro-orbital, e o nível de T4 circulante foi mensurado por ELISA.

\subsubsection{Farmacocinética}

A análise da depuração plasmática do hTSH-HEK foi realizada utilizando camundongos da linhagem BALB/c. Foi injetado intraperitonialmente $2 \mu \mathrm{g}$ da preparação em estudo a 5 animais e a coleta de sangue (via plexo retro-orbital) foi realizada em diferentes intervalos de tempo: 30, 60, 90, 120, 180, 240 e 300 minutos. A concentração de hTSH após cada intervalo de tempo foi determinada por IRMA.

Todos os ensaios que utilizaram animais foram conduzidos de acordo com as leis nacionais de proteção aos animais e foram aprovados pelo Comitê de Ética, protocolo 168/16.

\subsubsection{Espectrometria de massa (MALDI-TOF)}

A massa molecular do hTSH-HEK (aproximadamente $100 \mu \mathrm{g}$ de amostra) foi determinada por espectrometria de massa MALDI-TOF (Matrix Assisted Laser Desorbition Ionization - Time of Flight Mass Spectrometry), em um sistema Voyager DE BioSpectrometry Workslation (Applied Biosystem Sciex, Framingham, MA), operado em modo linear do íon positivo, utilizando uma solução saturada de ácido sinapníco (AS) em 50\% de acetonitrila e 0,1\% de ácido trifluoracético como matriz. O espectro foi obtido pelo acúmulo de 100 disparos e foi calibrado com um padrão externo (ProMix 3; LaserBiolabs). Esta análise foi realizada no laboratório Proteodynamics SARL (Riom, França). 


\subsubsection{Análise de carboidratos}

A análise das estruturas de carboidratos foi realizada no laboratório Proteodynamics SARL (Riom, França). O perfil dos glicanos da amostra de hTSH-HEK foi obtido após a digestão com glicosidase e permetilação dos N-glicanos. A amostra foi denaturada com $0,5 \%$ de dodecil sulfato de sódio (SDS) e $1 \%$ de $\beta$-mercaptoetanol $\left(90^{\circ} \mathrm{C}, 10\right.$ minutos) e deglicosilada por digestão enzimática, tratando por $15 \mathrm{~h}$ a $37^{\circ} \mathrm{C}$ com 20 unidades de PNGase $\mathrm{F}$ da Roche Applied Science (Mannheim, Alemanha), de acordo com Fogli A e col., 2012. A deglicosilação foi monitorada em um gradiente NuPage de 4-12\% MES (Invitrogen) por coloração com Comassie blue. Os N-glicanos foram purificados utilizando uma coluna de carbono grafitizado, sendo eluidos com $25 \%$ de acetonitrila contendo $0,1 \%$ de TFA e posteriormente liofilizados. A permetilização foi realizada com $\mathrm{NaOH}$ e dimetilsulfato e os produtos dessa reação purificados em coluna C18 Sep Pak Plus (Waters, Milford, MA). Os N-glicanos eluidos foram solubilizados 50:50 água/metanol, misturados com ácido dihidroxibenzeno (DHB) e analisados por espectrometria de massa MALDI-TOF-MS.

$\mathrm{O}$ espectro de massa dos $\mathrm{N}$-glicanos permetilados ressuspensos em $20 \mu \mathrm{L}$ de $50 \%$ methanol/água foi adquirido no modo linear do íon positivo $(\mathrm{m} / \mathrm{z}$ de $1000-5000 \mathrm{Da})$, em um sistema MALDI-TOF DE PRO (Applied Biosystem Sciex, Framingham, MA), com DHB como matriz $(10 \mathrm{mg} / \mathrm{mL}$, razão $1: 1)$. O espectro foi obtido pelo acúmulo de 500 disparos e foi calibrado com padrão externo. Os dados do MALDI-TOF-MS foram processados usando o programa DataExplorer 4.0 para gerar os valores de $\mathrm{m} / \mathrm{z}$ e para comparar as intensidades. A interpretação das estruturas dos glicanos correspondente às massas monoisotópicas foi realizada usando a ferramenta EXPAZY GlycoMod (http://web.expasy.org/glycanmass/) e o programa GlycoWorkBench. O perfil de glicanos e a intensidade relativa (\%) de cada glicano foram utilizados para calcular a massa média dos N-glicanos presentes na molécula de hTSHHEK. Por estequiometria, foi calculada também a contribuição de cada monossacarídeo a cada glicano. A ocupação dos sítios de glicosilação foi calculada utilizando a massa média do glicano (AGM), obtida a partir do perfil dos $\mathrm{N}$-glicanos e da massa molecular total da glicoproteína, obtida por MALDI-TOF-MS, de acordo com a seguinte relação: 


\section{AGM $x \mathbf{N}^{0}$ de sítios ocupados = Massa de carboidratos}

A massa de carboidratos é obtida pela relação:

\section{Massa de carboidratos $=$ massa molecular - backbone hTSH}

O backbone do hTSH é 24330 Da (Cole ES e col., 1993), calculado pela análise da sequência de aminoácidos do hTSH recombinante (Thyrogen ${ }^{\circledR}$ ) e de suas subunidades.

Conhecendo a ocupância é então possível determinar a razão molar ( $\mathrm{mol} / \mathrm{mol})$ de cada monossacarídeo. 


\section{RESULTADOS}

\subsection{Purificação dos produtos de PCR}

A Figura 4 mostra a análise dos produtos de PCR em gel de agarose, onde ficam evidenciadas as bandas correspondentes às subunidades $\alpha$ (362 pb) e $\beta$ (428 pb), que foram posteriormente purificadas.

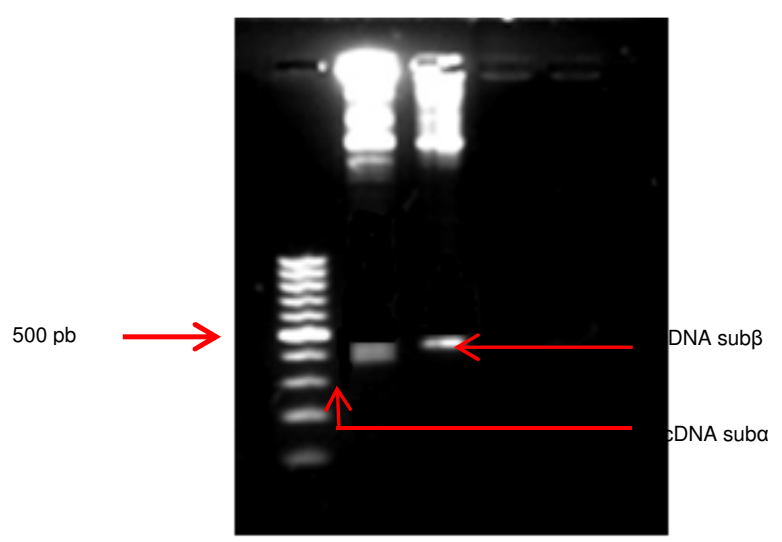

Figura 4. Gel de agarose 1,2\% corado com brometo de etídio. Poço 1: marcador de peso molecular; Poço 2: produto de PCR da subunidade $\alpha$; Poço 3: produto de PCR da subunidade $\beta$.

\subsection{Sequenciamento do vetor}

As Figuras 5 e 6 mostram a análise comparativa entre as sequências teórica $(\mathrm{O})$ experimental (O) das subunidades $\alpha$ e $\beta$, confirmando a correta orientação do inserto. 


\begin{tabular}{|c|c|c|c|c|}
\hline 460 & 470 & 480 & 490 & 500 \\
\hline АТСAAACTCA & TTACTAACCG & GTAGGGATCG & AACCCTTGCC & ATGGATTACT \\
\hline----------- & ----------- & ---------- & ----------- & ATGGATTACT \\
\hline$\left.\cdots\right|_{510} \cdots 1$ & $\left.\cdots\right|_{520} \cdots 1$ & $\cdots+1 \ldots 1$ & $\cdots{ }_{540} \cdots \mid$ & $\cdots+\cdots \mid$ \\
\hline ACAGAAAATA & TGCAGCTATC & TTTCTGGTCA & CATTGTCGGT & GTTTCTGCAT \\
\hline CAGAAAATA & TGCAGCTATC & TTTCTGGTCA & CATTGTCGGT & GTTTCTGCAT \\
\hline$\cdots+\left.\right|_{560} \cdots \mid$ & $\cdots||_{570} \ldots \mid$ & $\cdots+\ldots \mid$ & $\cdots\left|{ }_{590} \cdots\right|$ & $\left.\cdots\right|_{600} \ldots \mid$ \\
\hline TTCTCCATT & CCGCTCCTGA & TGTGCAGGAT & TGCCCAGAAT & GCACGCTACA \\
\hline GTTCTCCATT & CCGCTCCTGA & TGTGCAGGAT & TGCCCAGAAT & GCACGCTACA \\
\hline$\left.\cdots\right|_{610} \cdot \ldots \mid$ & $\left.\cdots\right|_{620} \cdots \mid$ & $\left.\cdots\right|_{630} \ldots \mid$ & $\left.\cdots\right|_{640} \cdots \mid$ & $\left.\cdots\right|_{650} \cdots \mid$ \\
\hline$G A A A A C C C A$ & TTCTTCTCCC & AGCCGGGTGC & CCCAATACTT & CAGTGCATGG \\
\hline GGAAAACCCA & TTCTTCTCCC & AGCCGGGTGC & CCCAATACTT & CAGTGCATGG \\
\hline$\left.\cdots\right|_{660} \ldots \mid$ & $\left.\cdots\right|_{670} \ldots \mid$ & $\left.\cdots\right|_{680} \ldots \mid$ & $\left.\cdots\right|_{690} \ldots \mid$ & $\cdots+1 \ldots 1$ \\
\hline GCTGCTGCTT & CTCTAGAGCA & TATCCCACTC & CACTAAGGTC & CAAGAAGACG \\
\hline GCTGCTGCTT & CTCCAGAGCA & TATCCCACTC & CACTAAGGTC & CAAGAAGACG \\
\hline$\cdots+1 \ldots \mid$ & $\cdots|\cdots|$ & ${ }_{730} \ldots|\cdots|$ & $\left.\cdots\right|_{740} \ldots \mid$ & 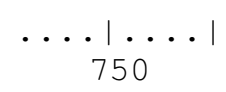 \\
\hline ATGTTGGTCC & AAAAGAACGT & CACCTCAGAG & TCCACTTGCT & GTGTAGCTAA \\
\hline ATGTTGGTCC & AAAAGAACGT & CACCTCAGAG & TCCACTTGCT & GTGTAGCTAA \\
\hline 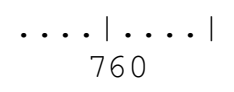 & $\cdots|\cdots|$ & ${ }_{780} \ldots|\cdots|$ & $\cdots||_{790} \ldots \mid$ & $\cdots+{ }_{800}$ \\
\hline ATCATATAAC & AGGGTCACAG & TAATGGGGGG & TTTCAAAGTG & GAGAACCACA \\
\hline ATCATATAAC & AGGGTCACAG & TAATGGGGGG & TTTCAAAGTG & GAGAACCACA \\
\hline $\begin{array}{l}.1 \ldots 1 \\
810\end{array}$ & $\left.\cdots\right|_{820} \ldots \mid$ & $\begin{array}{c}\cdots 1 \ldots 1 \\
830\end{array}$ & $\left.\cdots\right|_{840} \cdots \mid$ & $\left.\cdots\right|_{850} \ldots \mid$ \\
\hline CGGCGTGCCM & CTGCAGTACT & TGTTATTATC & ACAAMTCTTA & AAGGGTTCSA \\
\hline CGGCGTGCCA & CTCGAGTACT & TGTTAT-ATC & ACAAATCTTA & A---------- \\
\hline $\begin{array}{l}\cdots|\ldots| \\
860\end{array}$ & $\cdots|\cdots|$ & $\begin{array}{c}\cdots|\ldots| \\
880\end{array}$ & $\cdots{ }_{890} \cdots \mid$ & $\left.\cdots\right|_{900} \cdots$ \\
\hline CCTCTAGAS & TCCGGAGGCY & GGATCGGTCC & CGGTGTCYTC & TATGGAGGTC \\
\hline---- & ------ & ---------- & ------ & 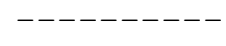 \\
\hline
\end{tabular}

Figura 5. Sequenciamento da subunidade $\alpha$ do hTSH. 


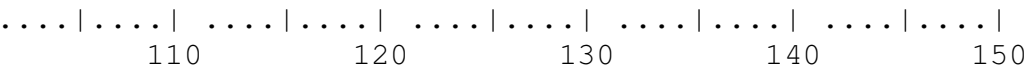

CTCCGGACTC TAGAGGATCG AACCCTTAGC ATGACTGCTC TCTTTCTGAT

ATGACTGCTC TCTTTCTGAT

$\ldots|\ldots| \ldots|\ldots| \ldots|\ldots| \ldots|\ldots| \ldots|\ldots| \ldots|\ldots| \ldots \mid$

$160-170-190-100$

GTCCATGCTT TTtGGCCTTG CATGTGgGCA AgCGATGTCT TTTTGTATTC GTCCAtGCtT tTtgGCCtTA CAtgtgGgCA AgCGAtgtCT tittgtAttC

$\ldots|\ldots| \ldots|\ldots| \ldots|\ldots| \ldots|\ldots| \ldots|\ldots| \ldots|\ldots| \ldots \mid$

$\begin{array}{lllll}210 & 220 & 230 & 240 & 250\end{array}$

CAACTGAGTA TACAATGCAC ATCGAAAgGA GAGAgtgTgC TTATTGCCTA

CAACTGAGTA tACAATGCAC ATCGAAAgGA GAgAgtgtgC tTAtTGCCTA

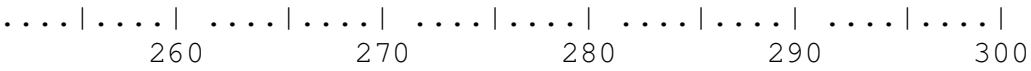

ACCATCAACA CCACCATCTG TGCTGGATAT TGTATGACAC GGGATATCAA

ACCATCAACA CCACCATCTG TGCTGGATAT TGtATGACAC GgGATAtCAA

$\left.\left.\ldots|\ldots|\right|_{310} \ldots|\cdots|_{320} \ldots|\cdots|_{330} \ldots|\cdots|_{340} \cdots|\cdots|\right|_{350}$

TGGCAAACTG TTTCTTCCCA AATATGCTCT GTCCCAGGAT GTTTGCACAT

TGGCAAACTG TTTCTTCCCA AATATGCTCT GTCCCAGGAT GTTTGCACAT

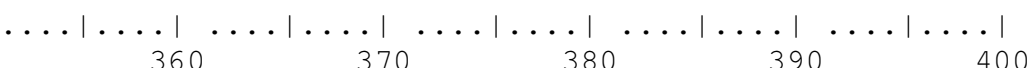

ATAGAGACTT CATCTACAGG ACTGTAGAAA TACCAGGATG CCCACTCCAT

AtAgAgACTT CATCTACAgG ACTGTAGAAA TACCAGGATg CCCACTCCAT

$\ldots|\ldots| \ldots|\ldots| \ldots|\ldots| \ldots|\ldots| \ldots|\ldots| \ldots|\ldots|$

$\begin{array}{lllll}410 & 420 & 430 & 440 & 450\end{array}$

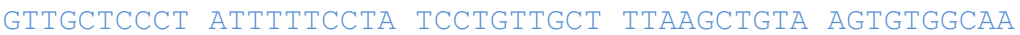

GTTGCTCCCT ATtTTTCCTA TCCTGTtGCT tTAAgCTGTA AgtgTGGCAA

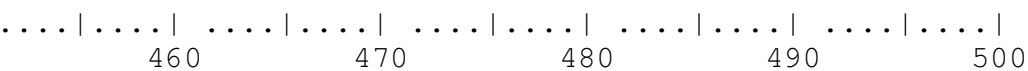

GIGCAATACT GACTATAGTG ACTGCATACA TGAAGCCATC AAGACAAACT GTGCAATACT GACTATAGTG ACTGCAtACA TGAAGCCATC AAGACAAACT

$\ldots|\ldots| \ldots|\ldots| \ldots|\ldots| \ldots|\ldots| \ldots|\ldots| \ldots|\ldots| \ldots \mid$

ACTGTACCAA ACCTCAGAAG TCTTATCTGG TAGGATTTTC TGTCTAAAAG ACTGTACCAA ACCTCAGAAG TCTTATCTGG TAgGAtTTtC TGTCTAAtAG

$\ldots|\ldots| \ldots|\ldots| \ldots|\ldots| \ldots|\ldots| \ldots|\ldots| \ldots|\ldots| \ldots \mid$

$560 \quad 570 \quad 580 \quad 590 \quad 600$

GGTTCGATCC CTACCGGTTA GTAATGAGTT TGATATCTCG ACAATCAACC

tGATATAATT -TGCAATtTG GT--TAAATG TGCtTGCCtG A-AAtAAAGC

Figura 6. Sequenciamento da subunidade $\beta$ do hTSH. 


\subsection{Crescimento celular e produtividade do hTSH}

A concentração de hTSH-HEK, resultante de 4 transfecções independentes, ao longo de um cultivo de 5 dias é mostrada na Figura 7.

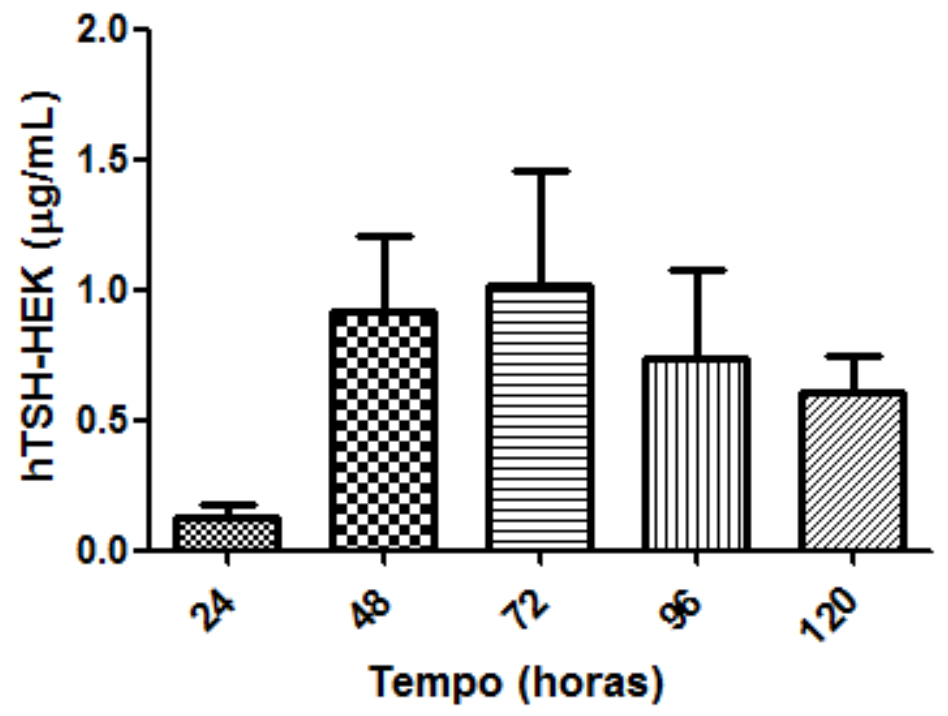

Figura 7. Concentração de hTSH ao longo de 5 dias de cultivo.

Observa-se que a concentração média mais alta de hTSH-HEK foi de $1,01 \pm 0,45 \mu \mathrm{g} / \mathrm{mL}$, alcançada após 72 horas. Após 5 dias de cultivo, a concentração de hTSH caiu cerca de $40 \%(0,61 \pm 0,14 \mu \mathrm{g} / \mathrm{mL})$.

O crescimento celular, analisado durante os 5 dias de cultivo, é mostrado na Figura 8, sendo a inclinação da curva de crescimento, que reflete a velocidade média de proliferação celular, de 1,2 × $10^{6}$ células/dia. 


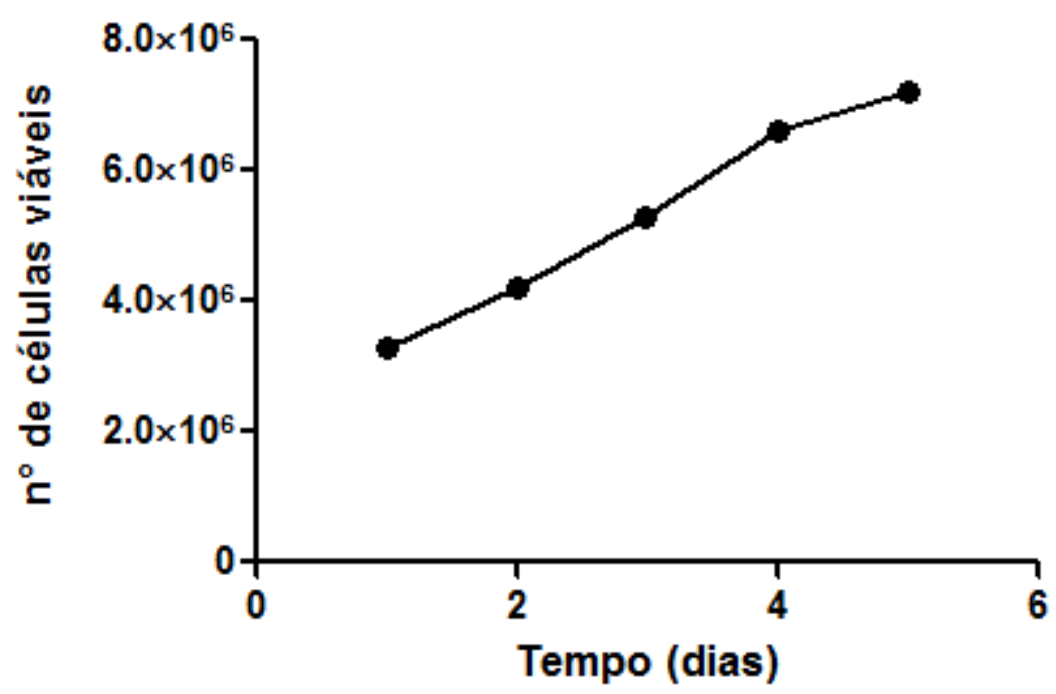

Figura 8. Número de células viáveis ao longo de 5 dias de cultivo.

Considerando o crescimento celular ao longo de 5 dias de cultivo e a produtividade volumétrica nesse período, foi calculada a produtividade específica $\left(\mu \mathrm{g} / 10^{6}\right.$ célula/dia) mostrada na Figura 9. A mais alta produtividade específica foi de $2,2 \mu \mathrm{g} / 10^{6}$ célula/dia

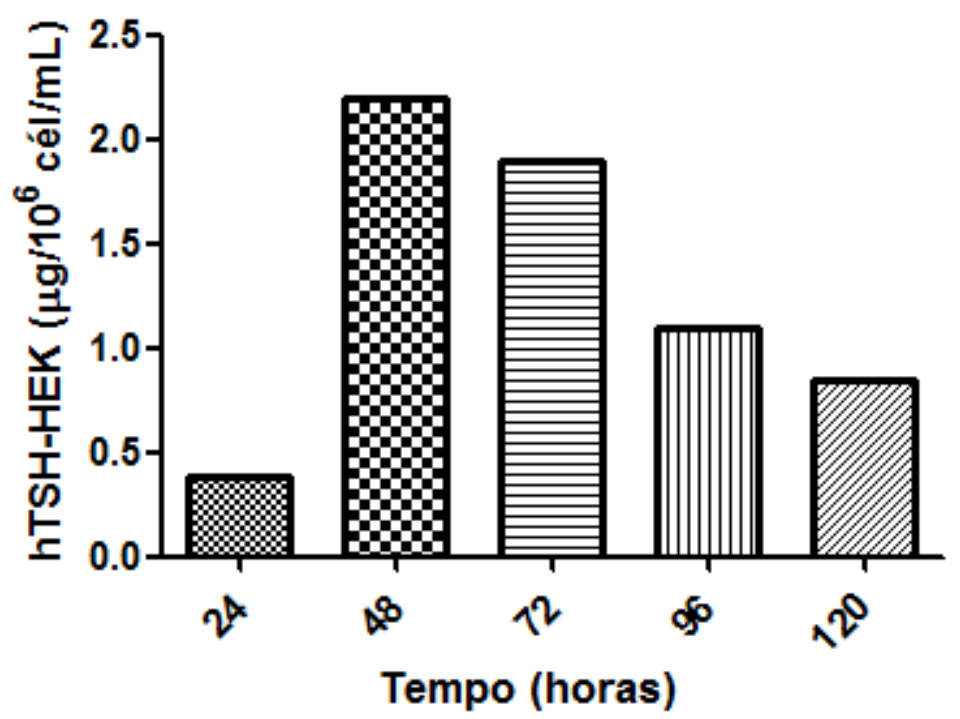

Figura 9. Produtividade específica de hTSH ao longo de 5 dias de cultivo. 


\subsection{Processo de obtenção do hTSH-HEK}

Para a separação da proteína de interesse de suas impurezas, o processo de purificação partiu de $3209 \mathrm{~mL}$ de meio condicionado, que foi concentrado para $271 \mathrm{~mL}$ (concentração de $\sim 12 \mathrm{x}$ ). Dois tipos de cromatografia (troca iônica e fase reversa) foram utilizadas (Figura 10).
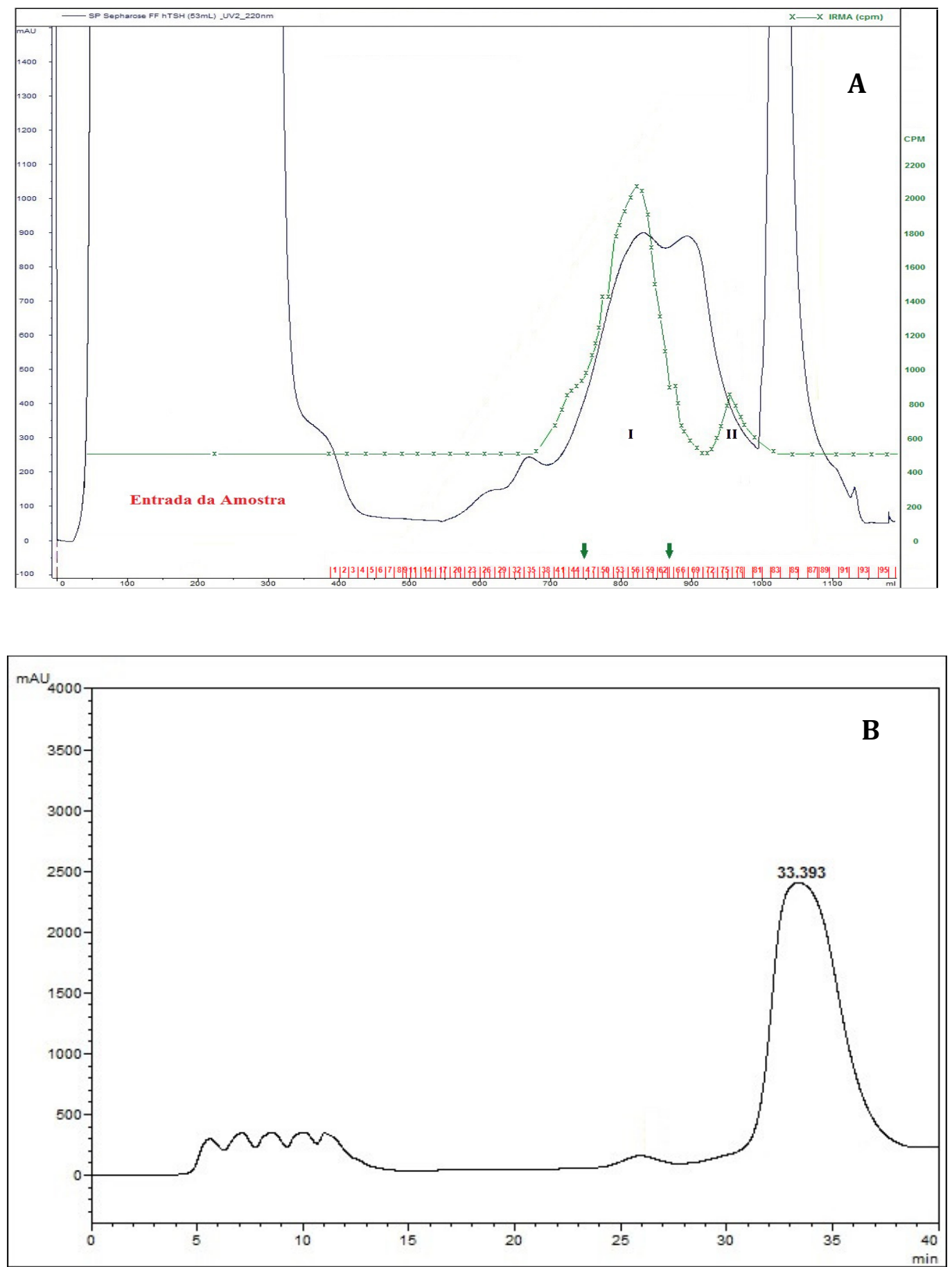

Figura 10. (A) Cromatografia de troca catiônica em SP-Sepharose FF. (B) Cromatografia de fase reversa. 
$\mathrm{Na}$ cromatografia de troca iônica em SP-Sepharose FF, as frações coletadas foram monitoradas por IRMA sendo identificada atividade imunológica em duas regiões (pico I e II). O pool das frações correspondentes ao pico I foi concentrado para $10 \mathrm{~mL}$, via dispositivo de filtração e submetido a uma cromatografia em RP-HPLC preparativa. O pico II, embora apresentando a proteína de interesse, foi descartado por conter muito mais impurezas.

A amostra resultante da última etapa foi dialisada em tampão fosfato de sódio $0,02 \mathrm{M}$ pH 7,0 + 0,15 M NaCl para retirada da acetonitrila.

A tabela 5 mostra os rendimentos das diferentes etapas do processo de purificação, bem como a fração de massa de hTSH.

Tabela 5: Processo de purificação do hTSH derivado de células HEK293.

\begin{tabular}{cccccc}
\hline Etapa & $\begin{array}{c}\text { Volume } \\
(\mathbf{m L})\end{array}$ & $\begin{array}{c}\mathbf{h T S H} \\
(\mathbf{\mu g} / \mathbf{m L})\end{array}$ & $\begin{array}{c}\text { Proteína total } \\
(\boldsymbol{\mu} \mathbf{g} / \mathbf{m L})\end{array}$ & $\begin{array}{c}\text { Recuperação da } \\
\text { etapa }(\%)\end{array}$ & $\begin{array}{c}\text { Fração de } \\
\text { massa } \\
(\%)\end{array}$ \\
\hline Meio condicionado & 271 & $11,3^{1}$ & 1616 & - & 0,70 \\
$\begin{array}{c}\text { Cromatografia de } \\
\text { troca iônica }\end{array}$ & 10 & $194,3^{1}$ & 391 & 63,4 & 49,7 \\
$\begin{array}{c}\text { Cromatografia de } \\
\text { fase reversa }\end{array}$ & 13 & $135,2^{2}$ & 145 & 90,6 & 93,2 \\
Diálise & 14,1 & $119,9^{2}$ & 132,5 & 96,2 & 90,5 \\
\hline
\end{tabular}

${ }^{1}$ Quantificação por RP-HPLC

${ }^{2}$ Quantificação por HPSEC

A recuperação total do processo foi de 55,2\%. A etapa da cromatografia de troca iônica foi onde ocorreu o maior fator de purificação $(71 \mathrm{x})$ e também as maiores perdas $(37 \%)$.

Uma baixa fração de massa $(<1 \%)$ foi determinada no meio condicionado. De fato, observando-se o perfil cromatográfico desta etapa, em HPSEC e RP-HPLC, fica evidenciada a presença de uma grande quantidade de impurezas, juntamente com o hTSH (Figura 11). Na Fig 11A observa-se picos de atividade imunológica tanto no tempo de retenção correspondente ao hTSH (17,5 minutos) quanto em tempos de retenção correspondentes a proteínas de alto peso molecular (12 - 15 minutos), possivelmente formas alteradas (agregado e dímero) de hTSH. Na Fig 11B observa-se que apenas o pico com tempo de retenção de 36,4 min apresenta atividade imunológica. 

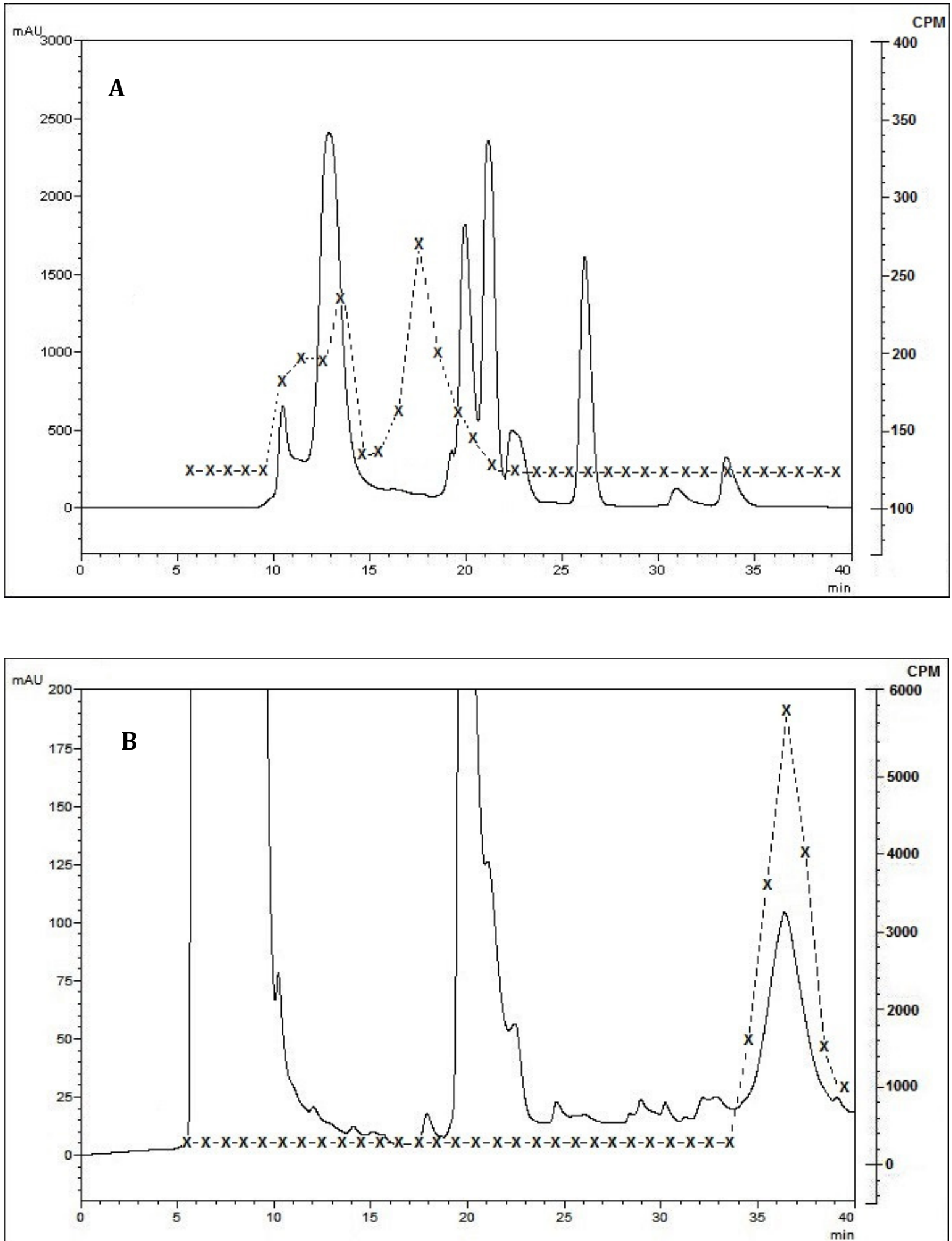

Figura 11. Perfil cromatográfico em HPSEC (A) e em RP-HPLC (B) do meio condicionado derivado do cultivo de células HEK293 transfectadas com as subunidades $\alpha$ e $\beta$ do hTSH. -- $\mathrm{A}_{220}$ x---x IRMA (cpm). 
A pureza do produto final foi avaliada por SDS-PAGE (Figura 12) onde é possível observar a progressiva eliminação dos contaminantes nas diferentes etapas de purificação, sendo o produto final tão puro quanto o padrão de referência.

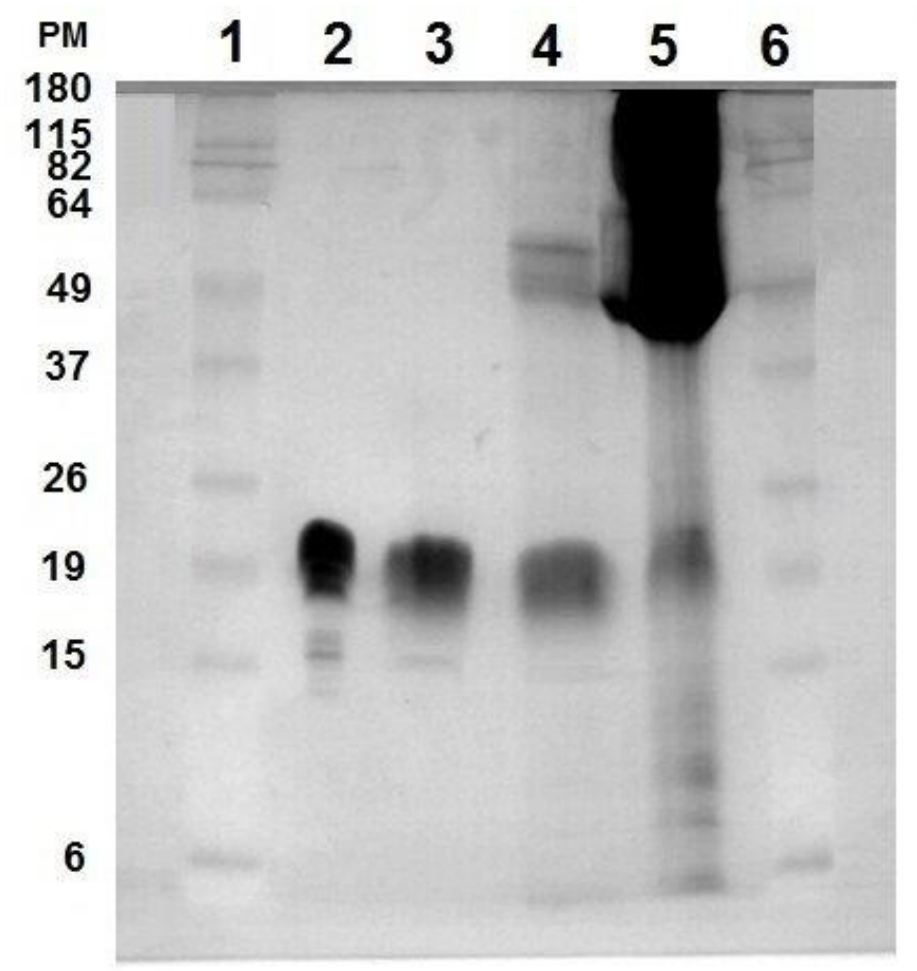

Figura 12. SDS-PAGE, em condições não redutoras, das diferentes etapas de purificação do hTSH. Colunas 1 e 6, marcadores de massa molecular; coluna 5, meio condicionado; coluna 4, eluato da troca catiônia; coluna 3, eluato da RP-HPLC; coluna 2, Thyrogen ${ }^{\circledR}$, utilizado como padrão de referência.

As diferentes etapas do processo de purificação foram analisadas também em HPSEC, que se baseia em diferenças de peso molecular (Figura 13). Enquanto no meio condicionado (Figura 13A) a presença do hTSH só foi possível de ser identificada por IRMA, no eluato da cromatografia de troca iônica já foi possível identifica-lo a partir da HPSEC, mesmo em presença de outras formas de maior peso molecular (Figura 13B). Após a etapa de cromatografia de fase reversa o produto já se encontra puro. O pico à direita do hTSH (Figura 13C) corresponde à acetonitrila, solvente orgânico utilizado nesta etapa de purificação, sendo este eliminado após a etapa de diálise (Figura 13D).

As diferentes etapas do processo de purificação também foram analisadas em RPHPLC, que se baseia em diferenças de hidrofobicidade (Figura 14). Observa-se que o hTSHHEK é bem mais hidrofóbico que as demais impurezas, o que permite a sua identificação já na primeira etapa do processo (Figura 14A). Após a segunda etapa (Figura 14B), a maior parte das impurezas já foram eliminadas. 

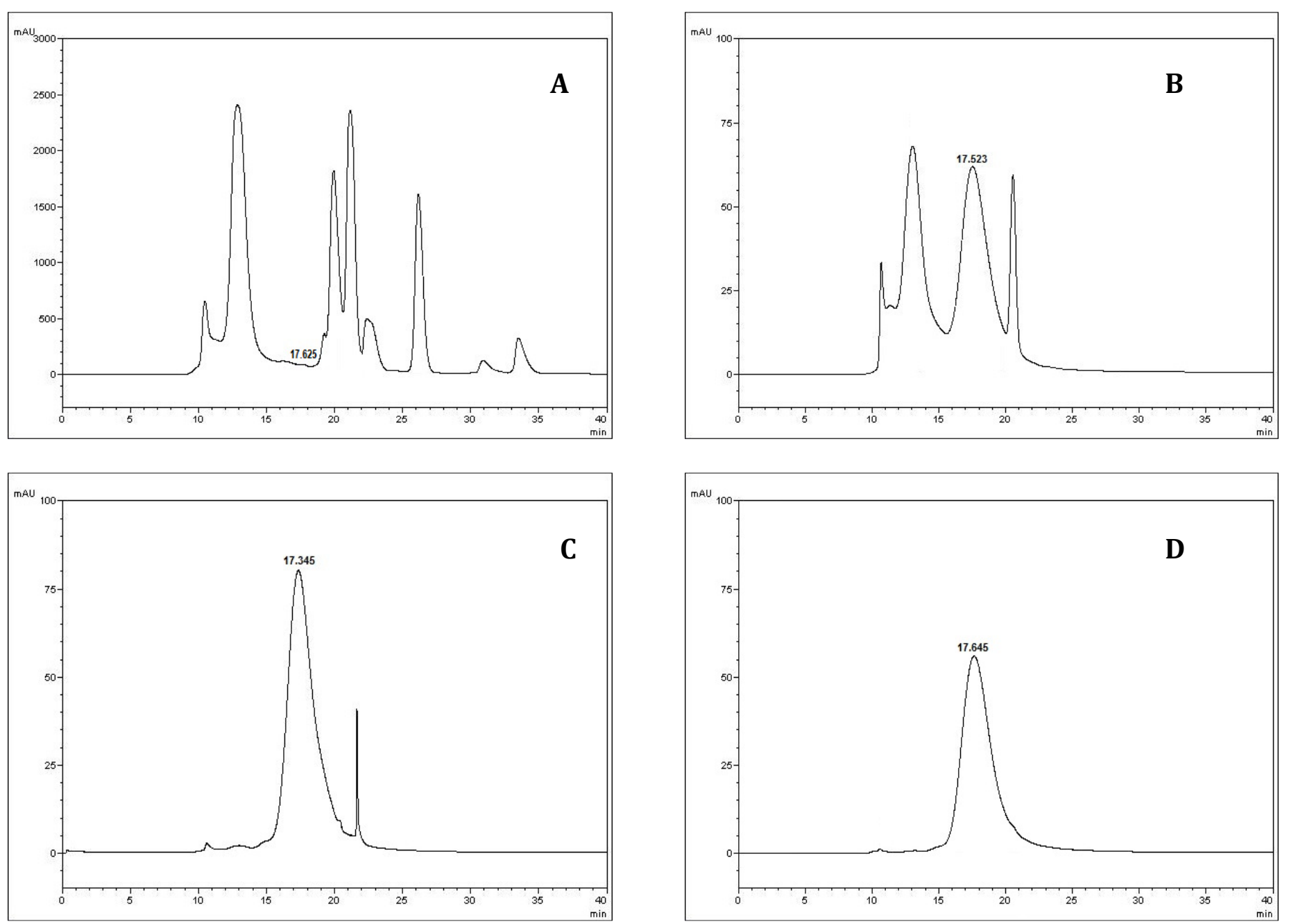

Figura 13. Perfil cromatográfico em HPSEC: (A) Meio condicionado; (B) Após cromatografia de troca catiônica; (C) Após cromatografia de fase reversa; (D) Produto dialisado. 

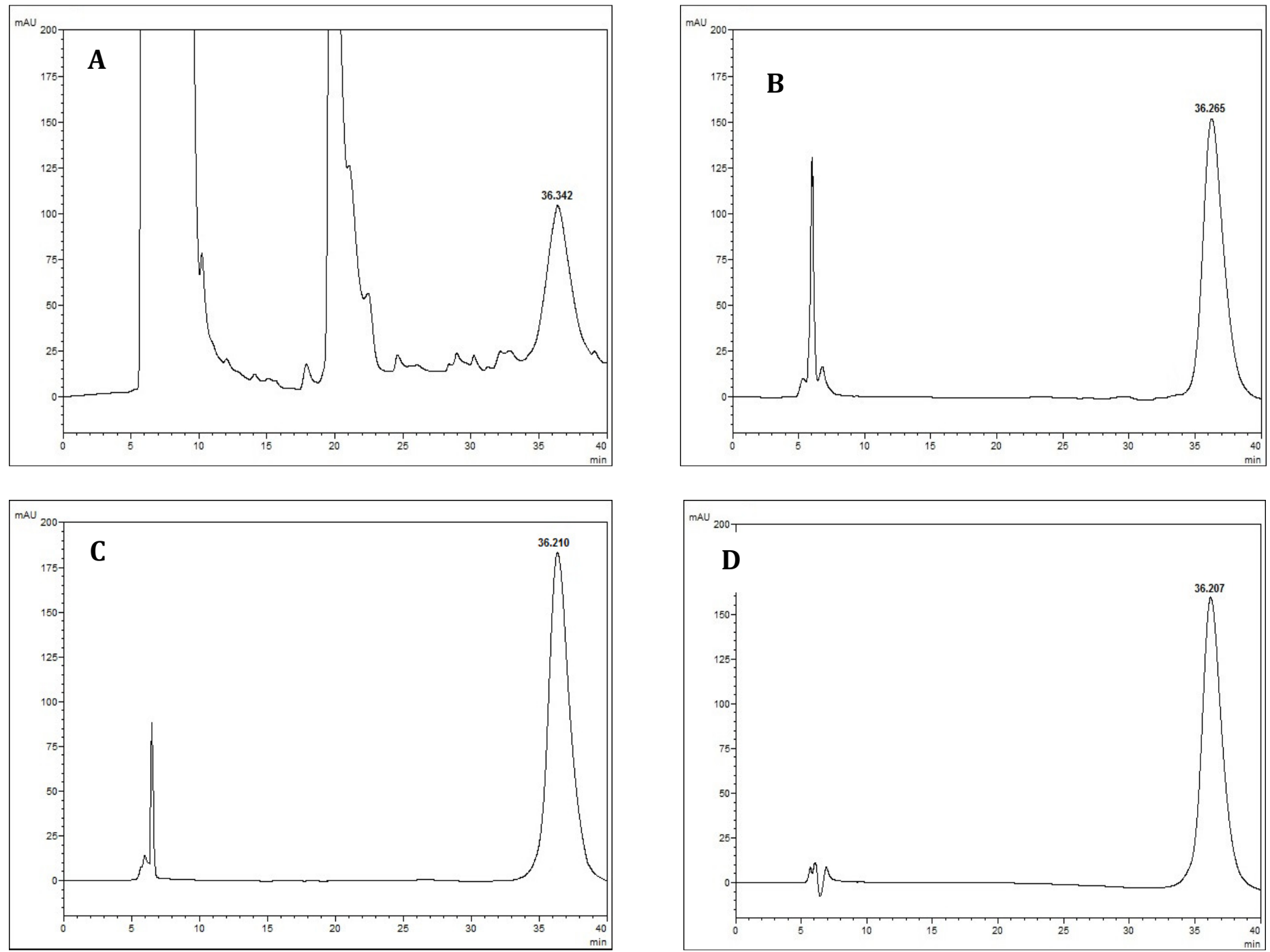

Figura 14. Perfil cromatográfico em RP-HPLC: (A) Meio condicionado; (B) Após cromatografia de troca catiônica; (C) Após cromatografia de fase reversa; (D) Produto dialisado. 


\subsection{Caracterização do Produto Purificado e Sua Comparação com Preparações de Diferentes Origens}

\subsubsection{Massa Molecular}

A massa molecular relativa $\left(\mathrm{M}_{\mathrm{r}}\right)$ da preparação hTSH-HEK foi determinada por espectrometria de massa MALDI-TOF. O espectro obtido permitiu a detecção simultânea dos monômeros das subunidades $\alpha$ e $\beta$ e do heterodímero (Figura 15). A massa molecular média destas formas, determinadas em três ensaios, foi de $13833,0 \pm 8,17$ para a subunidade $\alpha$, $15469,1 \pm 4,14$ para a subunidade $\beta$ e $29531,8 \pm 121,5$ para o heterodímero. Salienta-se que as somas das duas subunidades $(29302,1 \mathrm{Da})$ está de acordo com o valor encontrado para o heterodímero $(\alpha+\beta /$ het $=0,992)$, uma diferença $<1 \%$. No espectro obtido para o hTSH-HEK observou-se também a formação de homodímero da subunidade $\alpha(\alpha-\alpha=27480,2 \pm 339,6)$ e a presença de íons de carga dupla da subunidade $\alpha(\alpha / 2=6992,7 \pm 198,2)$. Nestes casos, a razão entre o valor calculado e o determinado experimentalmente foram respectivamente 1,007 e 0,989. Comparando-se a massa molecular do hTSH-HEK (29302) com a do hTSH-Pit (28524) e hTSH-CHO (29921), previamente determinadas em trabalhos do nosso grupo (Ribela MTCP e col., 2016), verificou-se que a massa do hTSH-HEK é 2,7\% maior do que a massa do hTSHPit e 2,1\% menor que a massa do hTSH-CHO. Nesta comparação utilizamos o valor de $\alpha+\beta$, por apresentarem melhor resolução que o heterodímero. 


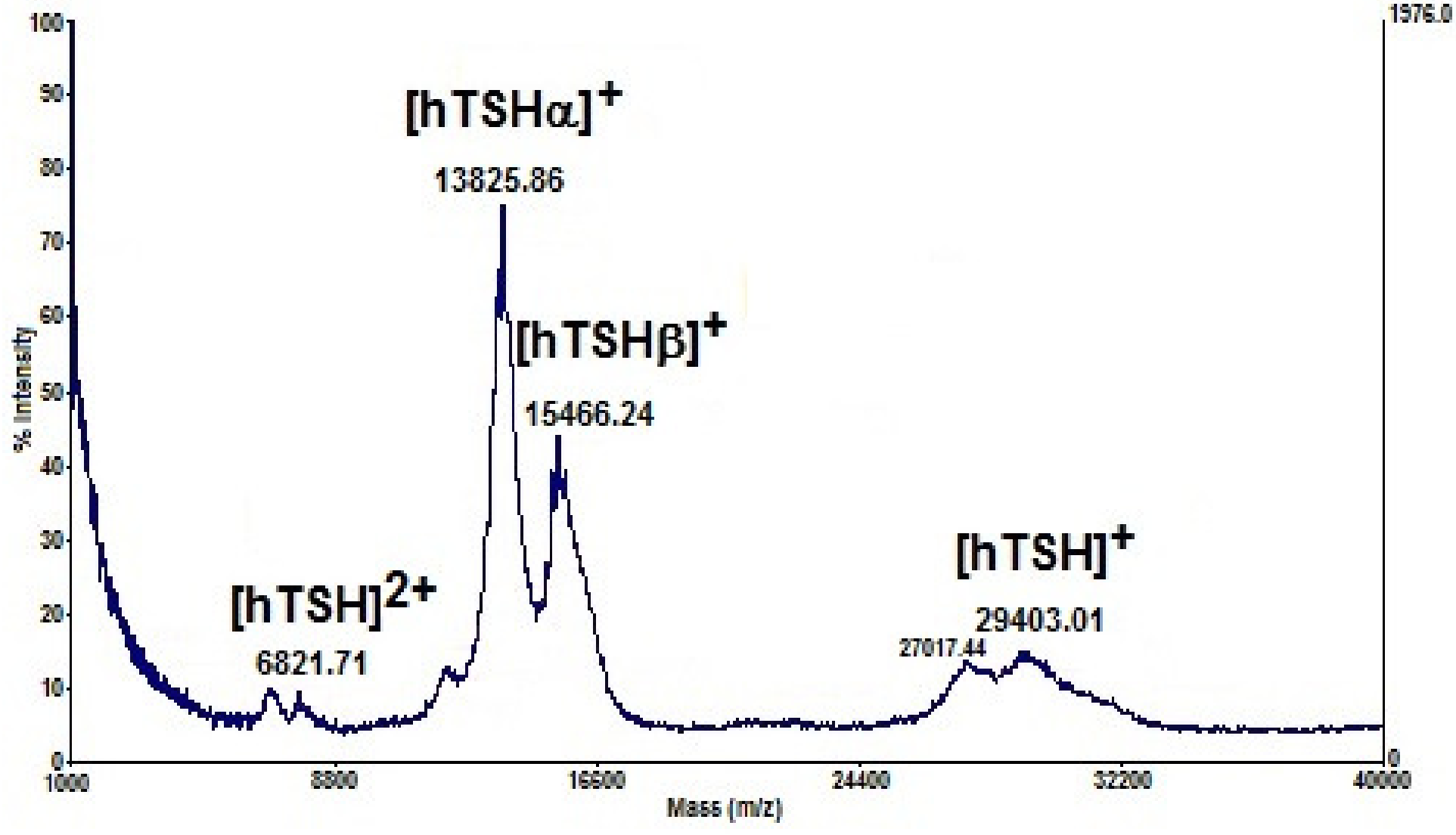

Figura 15. Espectro obtido por espectrometria de massa MALDI-TOF para o hTSH-HEK. 


\subsubsection{Carboidratos}

A Tabela 6 mostra a comparação das estruturas de carboidratos do hTSH-HEK determinadas no presente trabalho e das estruturas do hTSH derivado de células $\mathrm{CHO}$ e de origem hipofisária, determinadas em trabalho anterior do nosso grupo (Ribela MTCP e col., 2016).

No hTSH expresso em células HEK293 foram identificadas um total de 24 diferentes estruturas de carboidratos, todas elas complexas. Destas, apenas 2 estruturas tem uma intensidade relativa superior a 7,4\%. As duas estruturas mais relevantes são triantenárias com 1 resíduo terminal de galactose. Das estruturas do hTSH-HEK, apenas 3 delas são comuns ao hTSH-CHO e 12 comuns ao hTSH-Pit. No caso das preparações de hTSH-Pit e hTSH-CHO o número de estruturas de carboidratos são respectivamente 38 e 15 e além de estruturas complexas estas preparações tem uma pequena quantidade de estruturas hibridas, $9,8 \%$ e 1,2\% respectivamente.

A Figura 16 mostra esquematicamente as duas estruturas mais relevantes das preparações de hTSH de diferentes origens com frequências de 45,3\% no caso do hTSH-HEK, $28,1 \%$ no caso do hTSH-Pit e $68 \%$ no caso do hTSH-CHO. 
hTSH-HEK

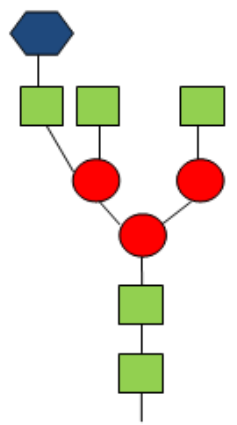

$15,4 \%$

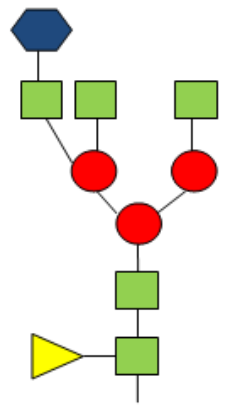

$29,9 \%$

\section{hTSH-Pit}
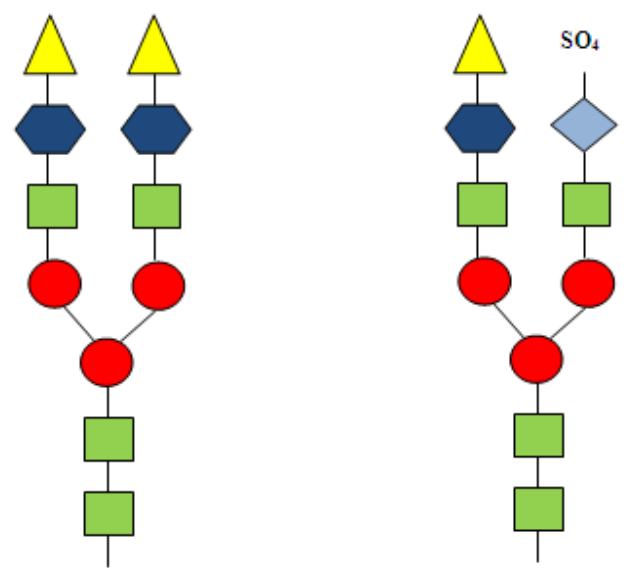

$14,1 \%$

$14,0 \%$

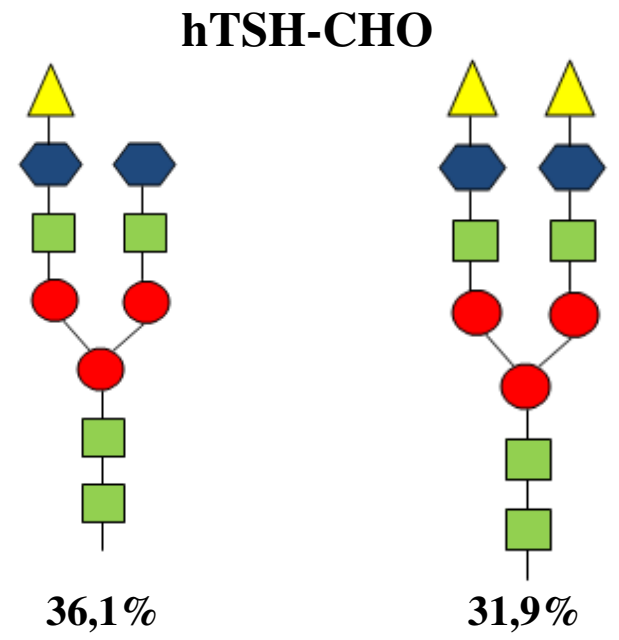

$>$ Fuc

$\mathrm{Gal}$

$>$ GalNac

GlcNac

Man

$\triangle$ NeuAc

Figura 16. Estruturas mais relevantes do hTSH de diferentes origens e intensidades relativas 
Tabela 6. Estruturas de carboidratos de hTSH de diferentes origens e intensidades relativas.

\begin{tabular}{|c|c|c|c|c|c|}
\hline & \multirow{2}{*}{$\begin{array}{c}\text { Massa do Glicano } \\
-\mathrm{H}_{2} \mathrm{O}\end{array}$} & \multirow[t]{2}{*}{ Estrutura do N-glicano } & \multicolumn{3}{|c|}{ Intensidade Relativa (\%) } \\
\hline & & & hTSH-HEK & hTSH-Pit & hTSH-CHO \\
\hline$\overline{1}$ & 1298,96 & $(\mathrm{GlcNAc})_{2}+(\mathrm{Man})_{3}(\mathrm{GlcNAc})_{2}$ & 0,3 & 0,0 & 0,0 \\
\hline 2 & 1378,43 & $(\mathrm{GalNAc})_{1}(\mathrm{GlcNAc})_{1}(\mathrm{Sulf})_{1}+(\mathrm{Man})_{3}(\mathrm{GlcNAc})_{2}$ & 0,0 & 5,1 & 0,0 \\
\hline 3 & 1444,53 & $(\mathrm{GlcNAc})_{2}(\mathrm{Fuc})_{1}+(\mathrm{Man})_{3}(\mathrm{GlcNAc})_{2}$ & 0,6 & 0,3 & 0,0 \\
\hline 4 & 1460,53 & $(\mathrm{Gal})_{1}(\mathrm{GlcNAc})_{2}+(\mathrm{Man})_{3}(\mathrm{GlcNAc})_{2}$ & 2,5 & 0,4 & 0,4 \\
\hline 5 & 1501,56 & $(\mathrm{GlcNAc})_{3}+(\mathrm{Man})_{3}(\mathrm{GlcNAc})_{2}$ & 3,5 & 0,0 & 0,0 \\
\hline 6 & 1524,49 & $(\text { GalNAc })_{1}(\text { GlcNAc })_{1}(\text { Sulf })_{1}(\text { Fuc })_{1}+(\text { Man })_{3}(\text { GlcNAc })_{2}$ & 0,0 & 1,5 & 0,0 \\
\hline 8 & 1548,54 & $(\mathrm{NeuAc})_{1}(\mathrm{Gal})_{1}(\mathrm{GlcNAc})_{1}+(\mathrm{Man})_{3}(\mathrm{GlcNAc})_{2}$ & 0,0 & 1,8 & 0,0 \\
\hline 9 & 1581,51 & $(\mathrm{GalNAc})_{1}(\mathrm{GlcNAc})_{2}(\mathrm{Sulf})_{1}+(\mathrm{Man})_{3}(\mathrm{GlcNAc})_{2}$ & 0,0 & 6,7 & 0,0 \\
\hline 10 & 1606,59 & $(\mathrm{Gal})_{1}(\mathrm{GlcNAc})_{2}(\mathrm{Fuc})_{1}+(\mathrm{Man})_{3}(\mathrm{GlcNAc})_{2}$ & 7,4 & 0,0 & 5,0 \\
\hline 11 & 1622,58 & $(\mathrm{Gal})_{2}(\mathrm{GlcNAc})_{2}+(\mathrm{Man})_{3}(\mathrm{GlcNAc})_{2}$ & 3,2 & 1,0 & 0,0 \\
\hline 12 & 1647,61 & $(\mathrm{GlcNAc})_{3}(\mathrm{Fuc})_{1}+(\mathrm{Man})_{3}(\mathrm{GlcNAc})_{2}$ & 1,9 & 1,8 & 0,0 \\
\hline 13 & 1663,61 & $(\mathrm{Gal})_{1}(\mathrm{GlcNAc})_{3}+(\mathrm{Man})_{3}(\mathrm{GlcNAc})_{2}$ & 15,4 & 0,0 & 0,0 \\
\hline 14 & 1686,54 & $(\text { GalNAc })_{1}(\text { GlcNAc })_{1}(\text { Sulf })_{1}(\text { Fuc })_{1}+(\text { Man })_{4}(\text { GlcNAc })_{2}$ & 0,0 & 0,7 & 0,0 \\
\hline 15 & 1694,60 & $(\mathrm{NeuAc})_{1}(\mathrm{Gal})_{1}(\mathrm{GlcNAc})_{1}(\mathrm{Fuc})_{1}+(\mathrm{Man})_{3}(\mathrm{GlcNAc})_{2}$ & 0,0 & 1,1 & 0,0 \\
\hline 17 & 1710,60 & $(\mathrm{NeuAc})_{1}(\mathrm{Gal})_{1}(\mathrm{GlcNAc})_{1}+(\mathrm{Man})_{4}(\mathrm{GlcNAc})_{2}$ & 0,0 & 0,0 & 1,2 \\
\hline 18 & 1743,56 & $(\mathrm{Gal})_{1}(\mathrm{GalNAc})_{1}(\mathrm{GlcNAc})_{2}(\mathrm{Sulf})_{1}+(\mathrm{Man})_{3}(\mathrm{GlcNAc})_{2}$ & 0,0 & 3,6 & 0,0 \\
\hline 19 & 1751,62 & $(\mathrm{NeuAc})_{1}(\mathrm{Gal})_{1}(\mathrm{GlcNAc})_{2}+(\mathrm{Man})_{3}(\mathrm{GlcNAc})_{2}$ & 0,0 & 1,3 & 0,5 \\
\hline 20 & 1768,64 & $(\mathrm{Gal})_{2}(\mathrm{GlcNAc})_{2}(\mathrm{Fuc})_{1}+(\mathrm{Man})_{3}(\mathrm{GlcNAc})_{2}$ & 3,5 & 0,6 & 0,0 \\
\hline 21 & 1809,67 & $(\mathrm{Gal})_{1}(\mathrm{GlcNAc})_{3}(\mathrm{Fuc})_{1}+(\mathrm{Man})_{3}(\mathrm{GlcNAc})_{2}$ & 29,9 & 0,8 & 0,0 \\
\hline 22 & 1825,66 & $(\mathrm{Gal})_{2}(\mathrm{GlcNAc})_{3}+(\mathrm{Man})_{3}(\mathrm{GlcNAc})_{2}$ & 6,7 & 0,0 & 0,0 \\
\hline 23 & 1850,69 & $(\mathrm{GlcNAc})_{4}(\mathrm{Fuc})_{1}+(\mathrm{Man})_{3}(\mathrm{GlcNAc})_{2}$ & 3,0 & 0,0 & 0,0 \\
\hline 24 & 1864,55 & $(\mathrm{GalNAc})_{2}(\mathrm{GlcNAc})_{2}(\mathrm{Sulf})_{2}+(\mathrm{Man})_{3}(\mathrm{GlcNAc})_{2}$ & 0,0 & 3,4 & 0,0 \\
\hline 25 & 1889,62 & $(\text { GalNAc })_{1}(\text { GlcNAc })_{2}(\text { Sulf })_{1}(\text { Fuc })_{1}+(\mathrm{Man})_{4}(\text { GlcNAc })_{2}$ & 0,0 & 1,4 & 0,0 \\
\hline 26 & 1889,62 & $(\mathrm{Gal})_{1}(\mathrm{GalNAc})_{1}(\mathrm{GlcNAc})_{2}(\mathrm{Sulf})_{1}(\mathrm{Fuc})_{1}+(\mathrm{Man})_{3}(\mathrm{GlcNAc})_{2}$ & 0,0 & 4,6 & 0,0 \\
\hline 27 & 1897,68 & $(\mathrm{NeuAc})_{1}(\mathrm{Gal})_{1}(\mathrm{GlcNAc})_{2}(\mathrm{Fuc})_{1}+(\mathrm{Man})_{3}(\mathrm{GlcNAc})_{2}$ & 0,0 & 1,0 & 0,0 \\
\hline 28 & 1913,68 & $(\mathrm{NeuAc})_{1}(\mathrm{Gal})_{2}(\mathrm{GlcNAc})_{2}+(\mathrm{Man})_{3}(\mathrm{GlcNAc})_{2}$ & 0,9 & 0,9 & 36,1 \\
\hline 29 & 1930,65 & $(\text { GalNAc })_{2}(\text { GlcNAc })_{2}(\text { Sulf })_{1}(\text { Fuc })_{1}+(\text { Man })_{3}(\text { GlcNAc })_{2}$ & 0,0 & 1,6 & 0,0 \\
\hline 30 & 1954,70 & $(\mathrm{NeuAc})_{1}(\mathrm{Gal})_{1}(\mathrm{GlcNAc})_{3}+(\mathrm{Man})_{3}(\mathrm{GlcNAc})_{2}$ & 1,9 & 0,7 & 0,0 \\
\hline 31 & 1955,72 & $(\mathrm{Gal})_{1}(\mathrm{GlcNAc})_{3}(\mathrm{Fuc})_{2}+(\mathrm{Man})_{3}(\mathrm{GlcNAc})_{2}$ & 6,2 & 0,8 & 0,0 \\
\hline 32 & 1971,72 & $(\mathrm{Gal})_{2}(\mathrm{GlcNAc})_{3}(\mathrm{Fuc})_{1}+(\mathrm{Man})_{3}(\mathrm{GlcNAc})_{2}$ & 3,9 & 0,0 & 0,0 \\
\hline 33 & 1996,75 & $(\mathrm{GlcNAc})_{4}(\mathrm{Fuc})_{2}+(\mathrm{Man})_{3}(\mathrm{GlcNAc})_{2}$ & 2,5 & 0,0 & 0,0 \\
\hline 36 & 2028,74 & $(\mathrm{Gal})_{2}(\mathrm{GlcNAc})_{4}+(\mathrm{Man})_{3}(\mathrm{GlcNAc})_{2}$ & 1,0 & 1,3 & 0,0 \\
\hline 37 & 2034,66 & $(\mathrm{NeuAc})_{1}(\mathrm{Gal})_{1}(\mathrm{GalNAc})_{1}(\mathrm{GlcNAc})_{2}(\mathrm{Sulf})_{1}+(\mathrm{Man})_{3}(\mathrm{GlcNAc})_{2}$ & 0,0 & 14,0 & 0,0 \\
\hline 38 & 2059,73 & $(\mathrm{NeuAc})_{1}(\mathrm{Gal})_{2}(\mathrm{GlcNAc})_{2}(\mathrm{Fuc})_{1}+(\mathrm{Man})_{3}(\mathrm{GlcNAc})_{2}$ & 0,0 & 0,0 & 3,4 \\
\hline 39 & 2100,76 & $(\mathrm{NeuAc})_{1}(\mathrm{Gal})_{1}(\mathrm{GlcNAc})_{3}(\mathrm{Fuc})_{1}+(\mathrm{Man})_{3}(\mathrm{GlcNAc})_{2}$ & 1,2 & 4,2 & 0,0 \\
\hline 40 & 2116,76 & $(\mathrm{NeuAc})_{1}(\mathrm{Gal})_{2}(\mathrm{GlcNAc})_{3}+(\mathrm{Man})_{3}(\mathrm{GlcNAc})_{2}$ & 0,7 & 0,0 & 0,0 \\
\hline 41 & 2117,78 & $(\mathrm{Gal})_{2}(\mathrm{GlcNAc})_{3}(\mathrm{Fuc})_{2}+(\mathrm{Man})_{3}(\mathrm{GlcNAc})_{2}$ & 0,0 & 0,0 & 0,5 \\
\hline 42 & 2174,80 & $(\mathrm{Gal})_{2}(\mathrm{GlcNAc})_{4}(\mathrm{Fuc})_{1}+(\mathrm{Man})_{3}(\mathrm{GlcNAc})_{2}$ & 1,7 & 1,4 & 0,0 \\
\hline 43 & 2180,72 & $2 \mathrm{uAc})_{1}(\mathrm{Gal})_{1}(\mathrm{GalNAc})_{1}(\mathrm{GlcNAc})_{2}(\mathrm{Sulf})_{1}(\mathrm{Fuc})_{1}+(\mathrm{Man})_{3}(\mathrm{GlcNAc})_{2}$ & 0,0 & 3,5 & 0,0 \\
\hline 44 & 2190,79 & $(\mathrm{Gal})_{3}(\mathrm{GlcNAc})_{4}+(\mathrm{Man})_{3}(\mathrm{GlcNAc})_{2}$ & 0,9 & 0,0 & 0,0 \\
\hline 45 & 2204,77 & $(\mathrm{NeuAc})_{2}(\mathrm{Gal})_{2}(\mathrm{GlcNAc})_{2}+(\mathrm{Man})_{3}(\mathrm{GlcNAc})_{2}$ & 0,0 & 14,1 & 31,9 \\
\hline 46 & 2245,80 & $(\mathrm{NeuAc})_{2}(\mathrm{Gal})_{1}(\mathrm{GlcNAc})_{3}+(\mathrm{Man})_{3}(\mathrm{GlcNAc})_{2}$ & 0,0 & 2,3 & 0,0 \\
\hline 47 & 2278,81 & $(\mathrm{NeuAc})_{1}(\mathrm{Gal})_{3}(\mathrm{GlcNAc})_{3}+(\mathrm{Man})_{3}(\mathrm{GlcNAc})_{2}$ & 0,0 & 0,0 & 2,7 \\
\hline 48 & 2350,83 & $(\mathrm{NeuAc})_{2}(\mathrm{Gal})_{2}(\mathrm{GlcNAc})_{2}(\mathrm{Fuc})_{1}+(\mathrm{Man})_{3}(\mathrm{GlcNAc})_{2}$ & 0,0 & 2,1 & 5,3 \\
\hline 49 & 2424,87 & $(\mathrm{NeuAc})_{1}(\mathrm{Gal})_{3}(\mathrm{GlcNAc})_{3}(\mathrm{Fuc})_{1}+(\mathrm{Man})_{3}(\mathrm{GlcNAc})_{2}$ & 0,0 & 0 & 0,5 \\
\hline 50 & 2553,91 & $(\mathrm{NeuAc})_{2}(\mathrm{Gal})_{2}(\mathrm{GlcNAc})_{3}(\mathrm{Fuc})_{1}+(\mathrm{Man})_{3}(\mathrm{GlcNAc})_{2}$ & 0,0 & 0,5 & 0,0 \\
\hline 51 & 2569,90 & $(\mathrm{NeuAc})_{2}(\mathrm{Gal})_{3}(\mathrm{GlcNAc})_{3}+(\mathrm{Man})_{3}(\mathrm{GlcNAc})_{2}$ & 0,0 & 0,0 & 6,9 \\
\hline 52 & 2684,97 & $(\mathrm{NeuAc})_{1}(\mathrm{Gal})_{3}(\mathrm{GalNAc})_{2}(\mathrm{GlcNAc})_{3}+(\mathrm{Man})_{3}(\mathrm{GlcNAc})_{2}$ & 0,0 & 0,8 & 0,0 \\
\hline 53 & 2715,96 & $(\mathrm{NeuAc})_{2}(\mathrm{Gal})_{3}(\mathrm{GlcNAc})_{3}(\mathrm{Fuc})_{1}+(\mathrm{Man})_{3}(\mathrm{GlcNAc})_{2}$ & 0,0 & 0,0 & 1,5 \\
\hline 54 & 2743,01 & $(\mathrm{Gal})_{3}(\mathrm{GlcNAc})_{4}(\mathrm{Fuc})_{1}+(\mathrm{Man})_{3}(\mathrm{GlcNAc})_{2}$ & 0,6 & 0,0 & 0,0 \\
\hline 55 & 2831,03 & $(\mathrm{NeuAc})_{1}(\mathrm{Gal})_{3}(\mathrm{GalNAc})_{2}(\mathrm{GlcNAc})_{3}(\mathrm{Fuc})_{1}+(\mathrm{Man})_{3}(\mathrm{GlcNAc})_{2}$ & 0,0 & 1,0 & 0,0 \\
\hline 56 & 2861,00 & $(\mathrm{NeuAc})_{3}(\mathrm{Gal})_{3}(\mathrm{GlcNAc})_{3}+(\mathrm{Man})_{3}(\mathrm{GlcNAc})_{2}$ & 0,0 & 0,6 & 3,5 \\
\hline 57 & 3007,06 & $(\mathrm{NeuAc})_{3}(\mathrm{Gal})_{3}(\mathrm{GlcNAc})_{3}(\mathrm{Fuc})_{1}+(\mathrm{Man})_{3}(\mathrm{GlcNAc})_{2}$ & 0,0 & 0,9 & 0,7 \\
\hline
\end{tabular}


Todas as estruturas do hTSH-CHO são galactosiladas, com predominância de estruturas com duas galactoses. Um menor número de glicanos com resíduos de Gal (1-3) são encontrados nas duas preparações de origem humana, com predominância de estruturas com uma galactose (Tabela 7).

Na preparação hTSH-HEK estruturas fucosiladas são bastante frequentes, enquanto nas preparações derivadas de células $\mathrm{CHO}$ e pituitária a fucose ocorre em menor incidência (Tabela 7).

Uma grande diferença encontrada entre as preparações de diferentes origens foi na frequência de estruturas sialiladas. Muito poucas estruturas são sialiladas na preparação hTSHHEK, sendo a preparação hTSH-CHO a mais sialilada (Tabela 7).

Tabela 7. Frequência de diferentes monossacarídeos (\%) em preparações de TSH de diferentes origens

\begin{tabular}{lccc}
\hline \multicolumn{1}{c}{ Monossacarídeo } & $\begin{array}{c}\text { hTSH-HEK } \\
(\boldsymbol{\%})\end{array}$ & $\begin{array}{c}\text { hTSH-Pit } \\
(\boldsymbol{\%})\end{array}$ & $\begin{array}{c}\text { hTSH-CHO } \\
(\boldsymbol{\%})\end{array}$ \\
\hline Galactose & 88,2 & 65,3 & 100 \\
Fucose & 63 & 34,2 & 16,9 \\
Ácido siálico & 4,7 & 50,8 & 94,2 \\
& & & \\
\hline
\end{tabular}

A análise do perfil de N-glicanos do hTSH-HEK mostrou que esta preparação contém glicanos complexos bi, tri e tetrantenários, com predominância dos triantenários, sendo as estruturas monoantenárias ausentes (Tabela 8). Diferentemente, as preparações derivadas de células $\mathrm{CHO}$ e pituitária tem as estruturas biantenárias predominantes. Estruturas tetraantenárias só não foram encontradas no hTSH-CHO.

Tabela 8. Intensidade relativa (\%) de GlcNAc em preparações de TSH de diferentes origens

\begin{tabular}{rccc}
\hline \multicolumn{1}{c}{ Antenaridade } & $\begin{array}{c}\text { hTSH-HEK } \\
(\boldsymbol{\%})\end{array}$ & $\begin{array}{c}\text { hTSH-Pit } \\
(\boldsymbol{\%})\end{array}$ & $\begin{array}{c}\text { hTSH-CHO } \\
(\boldsymbol{\%})\end{array}$ \\
\hline \multirow{2}{*}{ (GlcNAc $)_{1}$} & - & 17,9 & 1,2 \\
$(\mathrm{GlcNAc})_{2}$ & 18,4 & 64,9 & 82,6 \\
$(\mathrm{GlcNAc})_{3}$ & 71,3 & 14,4 & 16,3 \\
$(\mathrm{GlcNAc})_{4}$ & 10,3 & 2,7 & - \\
\hline
\end{tabular}

A preparação hTSH-HEK apresentou 2,3\% mais carboidratos que a preparação hTSHPit e 1,7\% menos carboidratos que a preparação hTSH-CHO (Tabela 9). Dos três sítios de N- 
glicosilação disponíveis, a preparação CHO apresentou o maior número de sítios ocupados, seguido do hTSH-HEK e hTSH-Pit (Tabela 9).

Tabela 9. Massa média dos glicanos, composição de carboidratos e ocupância, calculados a partir do perfil dos N-glicanos

\begin{tabular}{lccccc}
$\begin{array}{c}\text { Preparação de } \\
\text { hTSH }\end{array}$ & $\begin{array}{c}\text { Massa dos } \\
\text { carboidratos } \\
\text { MALDI-TOF* } \\
\text { (Da) }\end{array}$ & $\begin{array}{c}\text { Massa média } \\
\text { dos glicanos } \\
\text { (Da) }\end{array}$ & $\begin{array}{c}\text { Composição de } \\
\text { carboidratos } \\
(\%)\end{array}$ & $\begin{array}{c}\text { Sítios } \\
\text { ocupados } \\
\left(\mathbf{N}^{\mathbf{0}}\right)\end{array}$ & $\begin{array}{c}\text { Ocupância } \\
(\%)\end{array}$ \\
\hline hTSH-HEK & 4972 & 1860,8 & 17,0 & 2,67 & 89,1 \\
hTSH-Pit & 4194 & 1959,7 & 14,7 & 2,14 & 71,3 \\
hTSH-CHO & 5590 & 2202,3 & 18,7 & 2,79 & 93,1 \\
\hline *Calculada considerando a massa do backbone do hTSH de 24330 Da
\end{tabular}

O cálculo dos mossacarídeos Fuc, GalNac, GlcNAc, Gal, Man, SA e do Sulfato foi feito levando-se em conta a contribuição em massa de cada um deles nas diferentes estruturas das preparações de hTSH (Tabela 10). A preparação hTSH-HEK foi a que apresentou a maior quantidade de fucose, aproximadamente 5x mais que a preparação hTSH-CHO e praticamente 3x mais que a preparação hTSH-Pit. Com relação a GalNAc e Sulfato, apenas a preparação hTSH-Pit apresentou estas espécies. Quanto a GlcNAc, a preparação hTSH-HEK foi a que apresentou maior quantidade deste monossacarídeo, 22,5\% a mais que o hTSH-CHO e 38,3\% a mais que o hTSH-Pit. A Gal no hTSH-HEK é 42,4\% maior do que na preparação hTSH-Pit e 64,8\% menor que na preparação hTSH-CHO. Em relação à Man do hTSH-HEK, o hTSH-CHO apresenta praticamente a mesma quantidade e o hTSH-Pit apresenta $28,7 \%$ menos. O SA encontrado no hTSH-HEK foi 11,8 x menor do que no hTSH-Pit e 35,8x menor do que no hTSH-CHO.

Tabela 10. Razão molar de monossacarídeos ou sulfato por molécula de hTSH ( $\mathrm{mol} / \mathrm{mol})$, determinada baseada na análise dos N-glicanos

\begin{tabular}{lccccccc}
\hline \multicolumn{1}{c}{$\begin{array}{c}\text { Preparação de } \\
\text { hTSH }\end{array}$} & Fuc & GalNAc & GlcNAc & Gal & Man & AS & Sulfato \\
\hline hTSH-HEK & 2,20 & 0 & 14,22 & 3,21 & 8,72 & 0,12 & 0 \\
hTSH-Pit & 0,76 & 1,63 & 8,78 & 1,85 & 6,22 & 1,41 & 1,57 \\
hTSH-CHO & 0,47 & 0 & 11,02 & 5,29 & 8,48 & 4,29 & 0 \\
\end{tabular}




\subsubsection{Análise em HPLC}

Quando as preparações de diferentes origens foram analisadas em HPSEC e RP-HPLC, o hTSH-HEK apresentou tempo de retenção maior que o hTSH-CHO e que o hTSH-Pit, na seguinte ordem: $t_{R} \mathrm{CHO}<\mathrm{t}_{\mathrm{R}}$ Pit $<\mathrm{t}_{\mathrm{R}} \mathrm{HEK}$ (Tabela 11 e 12).

Tabela 11. Tempo de retenção de preparações de hTSH de diferentes origens em HPSEC

\begin{tabular}{cccc}
\hline Preparação & $\begin{array}{c}\text { Tempo de retenção }\left(\mathbf{t}_{\mathbf{R}}\right) \\
(\mathbf{m i n})\end{array}$ & $\begin{array}{c}\text { Diferença relativa } \\
\text { hTSH-HEK }(\%)\end{array}$ & Significância \\
\hline hTSH-HEK & $17,50 \pm 0,21$ & - & NS \\
hTSH-Pit & $17,08 \pm 0,08$ & -2.4 & P $>0,05$ \\
hTSH-CHO & $16,31 \pm 0,03$ & $-6,8$ & \\
\hline
\end{tabular}

Tabela 12. Tempo de retenção de preparações de hTSH de diferentes origens em RP-HPLC

\begin{tabular}{lccc}
\hline \multicolumn{1}{c}{ Preparação } & $\begin{array}{c}\left.\text { Tempo de retenção(t } \mathbf{t}_{\mathbf{R}}\right) \\
(\mathbf{m i n})\end{array}$ & $\begin{array}{c}\text { Diferença relativa } \\
\text { hTSH-HEK }(\%)\end{array}$ & $\begin{array}{c}\text { Significância } \\
\text { hTSH-HEK }\end{array}$ \\
hTSH-Pit & $35,74 \pm 0,67$ & - & NS \\
hTSH-CHO & $34,82 \pm 0,62$ & -2.6 & NS \\
\hline
\end{tabular}

No caso da HPSEC, a diferença do tempo de retenção entre as 2 preparações de origem humana não foi significativa. Entretanto, foi significativa a diferença entre o tempo de retenção do hTSH-CHO e hTSH-HEK.

Relativa à análise em RP-HPLC, há diferença de $~ 1$ minuto na eluição do hTSH-HEK e das outras duas preparações, mas estas diferenças não foram significativas.

O perfil cromatográfico em HPSEC destas preparações é mostrado na Figura 17. Observa-se que as 3 preparações apresentam o mesmo grau de pureza de $97 \%$.

O perfil cromatográfico em RP-HPLC destas preparações é mostrado na Figura 18. Observa-se que o hTSH-HEK é a preparação mais hidrofóbica. 

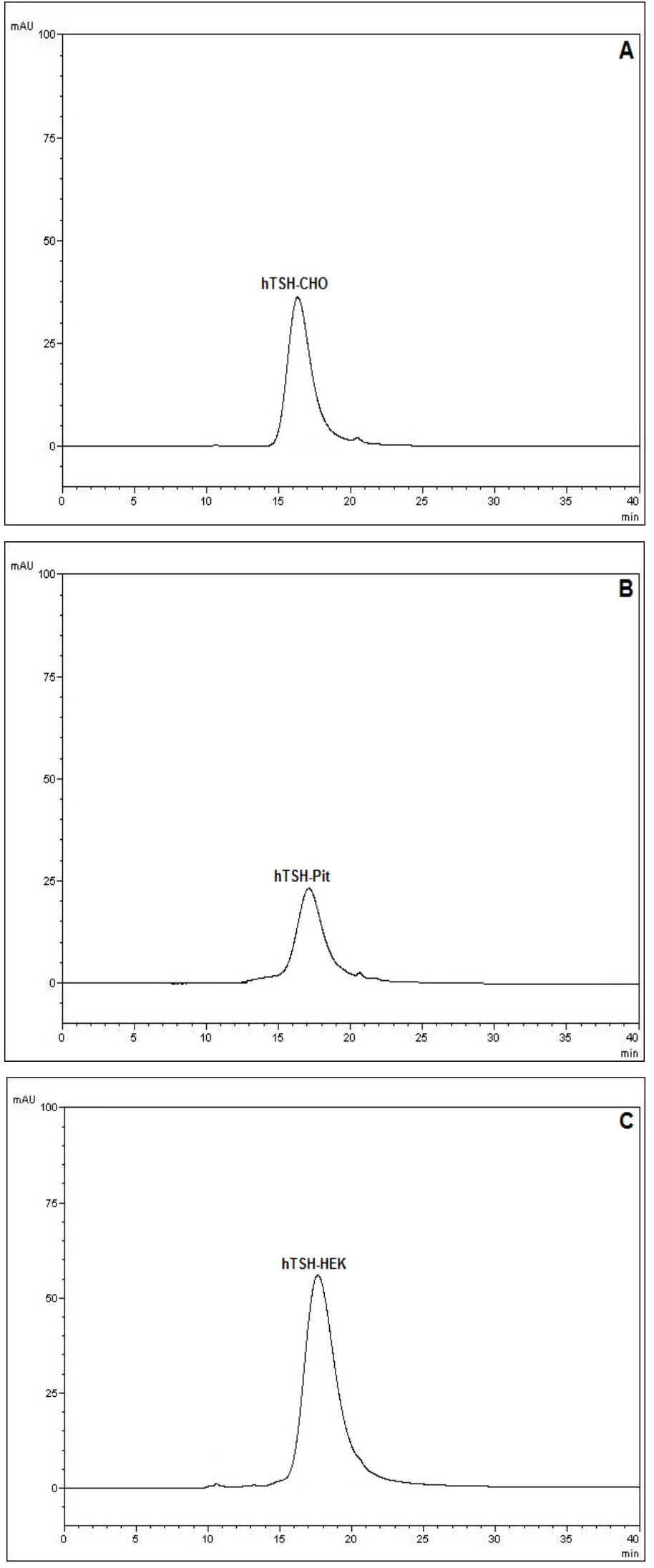

Figura 17. Perfil cromatográfico em HPSEC de preparações de hTSH de diferentes origens. 

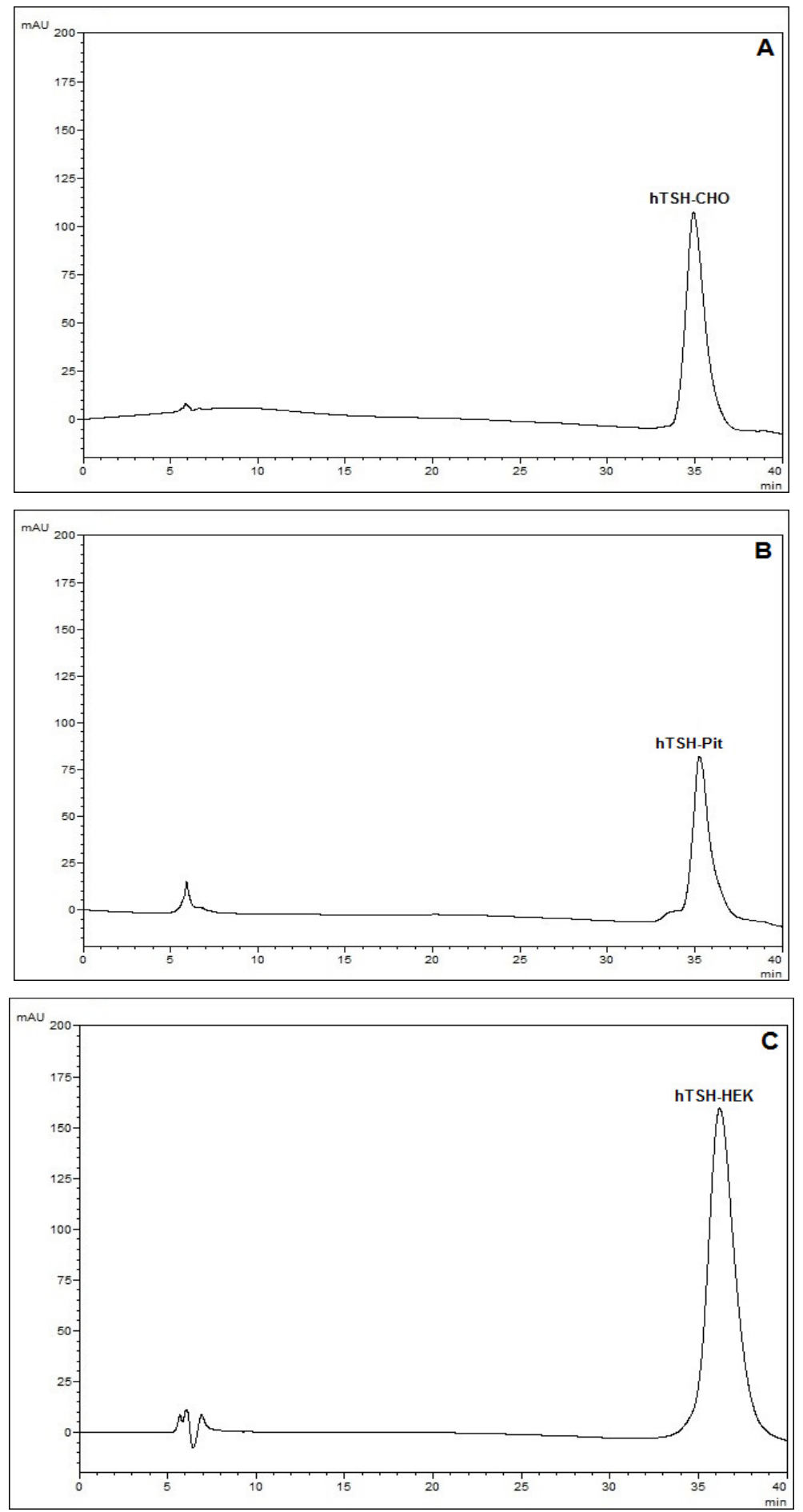

Figura 18. Perfil cromatográfico em RP-HPLC de preparações de hTSH de diferentes origens. 


\subsubsection{Análise em SDS-PAGE}

Quando analisadas em SDS-PAGE, as 3 preparações de hTSH migram como 2 bandas (subunidades $\alpha$ e $\beta$ ), observando-se uma pequena diferença de migração entre elas. As subunidades do hTSH-CHO migram menos que as subunidades das 2 outras preparações (Figura 19). Na literatura há relato semelhante relativo ao hTSH de origem hipofisária e derivado de células CHO (Carvalho CM e col., 2009). É possível observar também nessa análise que a pureza do produto obtida no presente trabalho é equivalente à das duas outras preparações.

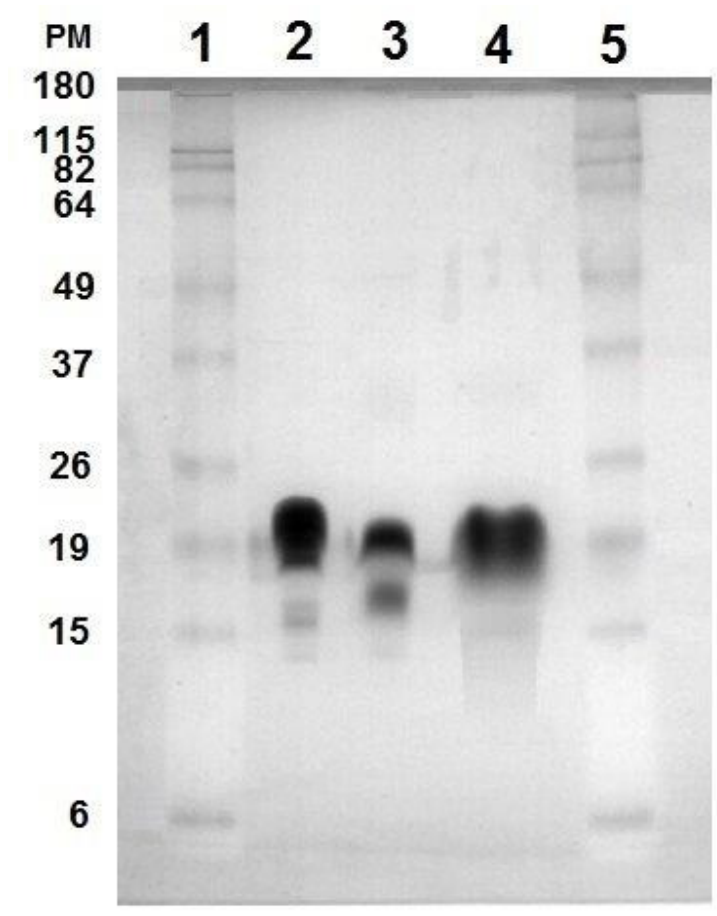

Figura 19. SDS-PAGE de hTSH de diferentes origens. (1) e (5) Marcador de peso molecular; (2) hTSH-CHO; (3) hTSH pituitário; (4) hTSH-HEK. 


\subsubsection{Farmacocinética}

Um exemplo de curva de concentração de hTSH-HEK no soro de camundongos em função do tempo é mostrada na Figura 20. A concentração plasmática máxima de hTSH-HEK foi atingida aos 60 minutos. Após 5 horas, apenas 14\% de TSH ainda permanece na circulação.

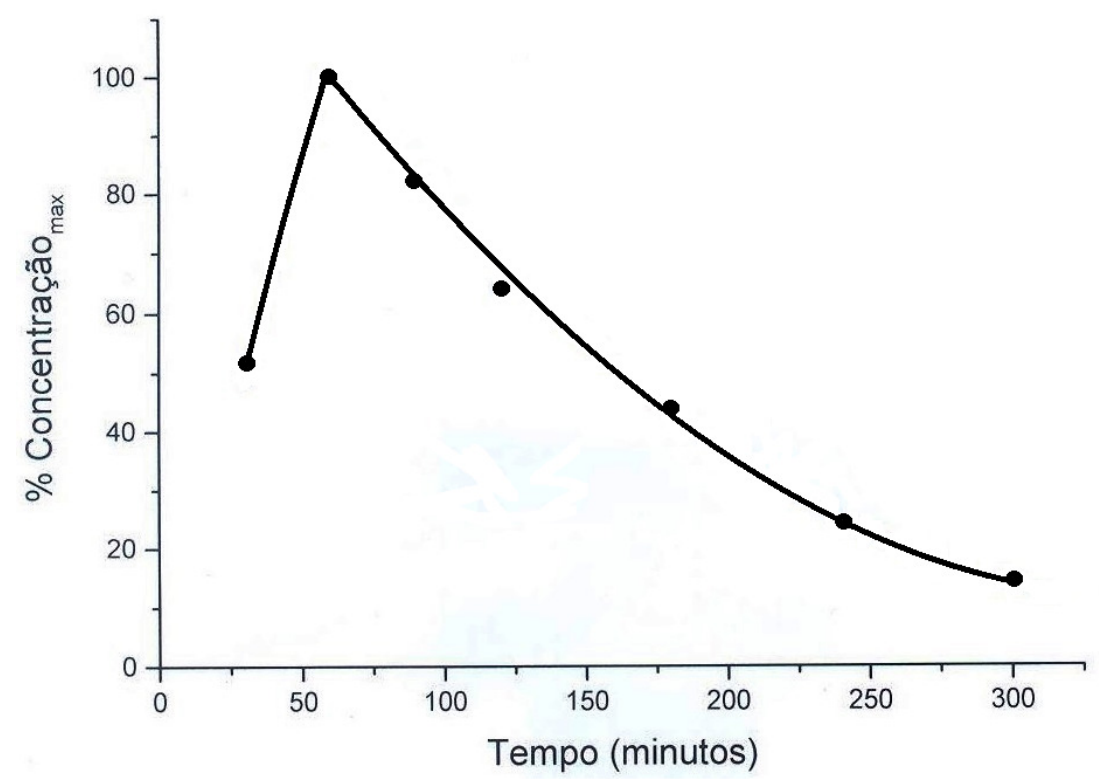

Figura 20. Concentração plasmática do hTSH-HEK em 5 horas.

Analisando o comportamento cinético das 3 preparações de origens diferentes observase que a meia-vida do hTSH-HEK é cerca de 1,5 vezes menor que a meia-vida do hTSH-CHO e 1,2 vezes menor do que o hTSH-Pit (Tabela 13). Enquanto o hTSH-CHO teve o máximo de absorção aos 90 minutos, ambos os hTSH de origem humana tiveram o máximo de absorção aos 60 minutos, gerando uma menor exposição do organismo ao hormônio. 
Tabela 13. Comportamento farmacocinético de preparações de hTSH de diferentes origens em 2 ensaios

\begin{tabular}{lccc}
\hline \multicolumn{1}{c}{ Preparação } & $\begin{array}{c}\text { Tempo de máxima } \\
\text { absorção }(\mathbf{m i n})\end{array}$ & $\begin{array}{c}\mathbf{T}_{\mathbf{1} / \mathbf{2}} \\
(\mathbf{m i n})\end{array}$ & AUC $(\boldsymbol{\mu g} . \mathbf{m i n} / \mathbf{m L})$ \\
\hline hTSH-HEK $^{1}$ & 60 & $74,3 \pm 18,03$ & $12194 \pm 2033,2$ \\
hTSH-Pit $^{2}$ & 60 & $89,7 \pm 0,42$ & $14269 \pm 2146,7$ \\
hTSH-CHO $^{3}$ & 90 & $115,1 \pm 3,12$ & $16155 \pm 1398,1$ \\
\hline
\end{tabular}

${ }^{1}$ Dados obtidos no presente trabalho

${ }^{2}$ Dados de Ribela MTCP e col., 2016

${ }^{3}$ Dados Damiani R e col., 2013

\subsubsection{Atividade biológica}

A atividade biológica de preparações de hTSH de diferentes origens foi avaliada por bioensaio in vivo, baseado no estímulo de liberação de $\mathrm{T}_{4}$ pela administração de hTSH, após prévia inibição do TSH endógeno dos camundongos Balb/C.

As respostas do $\mathrm{T}_{4}$ de camundongos $(\mathrm{n}=10)$ para as diferentes preparações administradas são mostradas na Tabela 14. Pode-se observar que a preparação de hTSH-HEK é biologicamente ativa, sendo 39\% menos ativa que a preparação hTSH-CHO e 16\% menos ativa que a preparação hTSH-Pit. Observa-se que a outra preparação de origem humana (hTSH-Pit) é também menos ativa que a derivada de $\mathrm{CHO}$, cerca de $27 \%$.

Tabela 14. Nível de $\mathrm{T}_{4}(\boldsymbol{\mu g} / \mathbf{d L})$, em preparações de hTSH de diferentes origens, determinado por bioensaio in vivo.

\begin{tabular}{lc}
\hline \multicolumn{1}{c}{ Preparação } & $\mathbf{T}_{\mathbf{4}}(\boldsymbol{\mu} \mathbf{g} / \mathbf{d L})^{1}$ \\
hTSH-HEK & $2,98 \pm 0,33$ \\
hTSH-Pit & $3,55 \pm 0,52$ \\
hTSH-CHO & $4,86 \pm 0,77$ \\
\hline
\end{tabular}




\subsection{DISCUSSÃO}

Neste trabalho foi obtida a tireotrofina humana recombinate expressa em células embrionárias de rim humano (HEK 293). Pelo que é do nosso conhecimento não há nenhum estudo na literatura sobre produção de hTSH recombinante em células humanas. Até o presente momento, todo o hTSH descrito na literatura, tanto pelo nosso grupo (Peroni CN e col., 2002) quanto por Cole ES e col. (1993) é derivado de células de ovário de hamster chinês (CHO), inclusive o único produto comercial disponível.

Um sistema eficiente de expressão transiente, utilizando o vetor comercial TOPO pcDNA 3.4 contendo os genes das subunidades $\alpha$ e $\beta$ do hTSH na mesma proporção empregada por Peroni e col. (2002), foi utilizado para a obtenção do hTSH-HEK.

Nas condições de transfecção estabelecidas neste trabalho obteve-se uma produtividade específica de 2,1 $\mu \mathrm{g} / 10^{6}$ cel./ dia e uma concentração de hTSH-HEK no meio condicionado de $0,95 \mu \mathrm{g} / \mathrm{mL}$. Estes valores são comparáveis em termos de produtividade específica aos reportados por Damiani R e col. (2009) para o hTSH derivado de células CHO modificadas para uma sialilação mais próxima da humana, isto é com configurações $\alpha_{2,3}$ e $\alpha_{2,6}$. Entretanto, estes valores são menores que aqueles reportados por Cole ES e col. (1993) (4,5 $\left.\mu \mathrm{g} / 10^{6} \mathrm{cel} / \mathrm{dia}\right)$ e por Peroni CN. e col. (2002) (7,2 $\left.\mu \mathrm{g} / 10^{6} \mathrm{cel} / \mathrm{dia}\right)$ para o hTSH derivado de células CHO não modificadas. De qualquer forma estes níveis de hTSH foram adequados para a obtenção de material para ser purificado e caracterizado.

O processo de purificação partiu de $438 \mathrm{mg}$ de material cru impuro e diluído em 3,2 L de meio de cultura (fração de massa de hTSH $=0,70 \%$ ). Após a primeira etapa do processo (concentração-purificação), foi obtido um enriquecimento de 71 vezes, gerando aproximadamente $4 \mathrm{mg}$ de proteína (fração de massa de hTSH $=49,6 \%$ ). Seguindo para a segunda etapa do processo (cromatografia de fase reversa), aproximadamente 1,8 $\mathrm{mg}$ de hTSH com pureza de reagente químico (>93\%) foi obtido.

No presente trabalho foi utilizado o mesmo processo de purificação descrito por Oliveira JE e col. (2007) para a purificação de hTSH derivado de células CHO. Neste caso, o material de partida era 1,6 vezes mais concentrado $(0,95$ versus $0,60 \mu \mathrm{g} / \mathrm{mL})$ e 2 vezes mais puro (fração de massa 0,70 versus $0,35 \%$ ) que o trabalho reportado na literatura. Em ambos os casos obteve- 
se um produto com pureza adequada, porém a recuperação final do processo do presente trabalho foi menor que à obtida na literatura (55\% versus $70 \%)$, embora ainda bastante útil.

A espectrometria de massa MALDI-TOF tem se mostrado uma ferramenta bastante importante para avaliar a identidade ou diferenças chaves entre preparações derivadas de hospedeiros diferentes. A massa do hTSH-HEK (29302), determinada por MALDI-TOF, é menor do que a massa do hTSH-CHO. Tal fato ficou também evidenciado na análise destas 2 preparações por HPLC de Exclusão molecular (HPSEC), onde uma diferença de tempo de retenção de $\sim 7 \%$ entre estas duas preparações foi observada, com o hTSH-CHO eluindo primeiro, refletindo portanto ter massa maior. Da mesma forma, a corrida eletroforética destas 2 preparações mostrou uma menor migração da preparação hTSH-CHO, caracterizando a sua massa maior. Com relação à massa do hTSH-Pit (28524), determinada por MALDI-TOF, a massa do hTSH-HEK foi 2,7\% maior. Na comparação destas 2 preparações por HPSEC, o hTSH-Pit eluiu primeiro, mas a diferença entre os tempos de retenção destas preparações não foi significativo.

A análise das tres preparações de diferentes origens em RP-HPLC (Tabela 12) revelou uma maior interação com a coluna de fase reversa da preparação hTSH-HEK, refletindo a maior hidrofobicidade relativa desta preparação. Esta preparação exibiu um tempo de retenção 3,6\% maior que o hTSH-CHO e 2,6\% maior que o hTSH-Pit, embora estas diferenças não tenham sido significativas. O hTSH-CHO apresentou um tempo de retenção $1 \%$ menor que o hTSHPit. Este fato já tinha também sido observado anteriormente na literatura. Oliveira JE e col.(2003) e Damiani R e col. (2009) obtiveram em seus estudos diferenças de -1,22\% e -1,14\%, respectivamente entre preparações derivadas de células $\mathrm{CHO}$ e hipofisária, o que pode ser explicado por diferenças de carboidratos nestes preparações.

Relativo ao perfil de N-glicanos obtido para o hTSH-HEK, foi verificado que o número (24) e quase todos os tipos de glicoestruturas desta preparação não foram comparáveis aos obtidos para a preparação hTSH-CHO, que é aquela usualmente utilizada na prática clínica. Apenas poucos $(14,2 \%) \mathrm{N}$-glicanos do hTSH-Pit foram comuns aos do hTSH-HEK, sendo que os glicanos predominantes nesta última (triantenários monogalactosilados com ou sem fucose), não foram identificados na preparação nativa. 
A preparação de hTSH derivada de células HEK 293 teve um grau de sialilação bem menor do que as outras duas preparações analisadas.

Já foi descrito na literatura que a sialilação é altamente específica do tipo de célula hospedeira (Zhang P e col.,2010).

Böhn E e col. (2015) obtiveram um grau de ácido siálico 5,5x menor na preparação recombinante humana de fator de coagulação VII derivada de células HEK293 (0,57 ac siálico/ molécula) do que na preparação derivada de células $\mathrm{CHO}$ (3,14 ac siálico/molécula).

Zhang P e col. (2010) mostraram por focalização isoelétrica (IEF) diferenças de sialilação na eritropoetina produzida em células CHO e células HEK293, estas últimas apresentanto um menor grau de sialilação.

Crosset A. e col. (2012) analisaram em IEF 12 proteínas de peso molecular entre 10000 e 53000 Da expressas em células CHO e HEK293 e detectaram que as proteínas expressas em células $\mathrm{CHO}$ tem isoformas mais acídicas comparadas às proteínas derivadas de células HEK, indicando a menor quantidade de ácido siálico das preparações derivadas de células HEK.

A quantidade de ácido siálico de uma glicoproteína é afetada por dois processos opostos: a adição intracelular do ácido siálico por sialiltransferases e a remoção extracelular de ácido siálico por clivagem enzimática via sialidase. A adição intracelular do ácido siálico é a última etapa do processo de glicosilação que ocorre no trans-Golgi. Isto envolve a transferência enzimática do ácido siálico do nucleotídeo precursor (CMP-ácido siálico) para galactose disponível na estrutura do glicano emergente, que é ligado à nova proteína sintetizada. Fatores que podem influenciar o nível de sialilação incluem disponibilidade de CMP-ácido siálico, a atividade de enzimas sialiltransferase e galactosiltransferase e a disponibilidade de galactose na estrutura do glicano emergente (Jing Y e col., 2010).

A diminuição do ácido siálico no hTSH-Pit pode ser associada com a menor disponibilidade de galactose. De fato, observa-se que a razão molar AS/Gal nesta preparação $(0,76)$ e no hTSH-CHO $(0,81)$ são da mesma ordem. Isto, entretanto, não ocorre no hTSH-HEK onde esta razão é 20 vezes menor $(0,037)$, sugerindo que a diminuição do ácido siálico possa ter ocorrido também por ação de sialidases.

Outra diferença bastante significativa observada nas preparações analisadas foi a maior quantidade de fucose presente na preparação derivada de células HEK293. Tal fato foi também observado por Böhn E. e col. (2015) que reportaram 5x mais fucose na preparação recombinante de fator de coagulação VII derivada de células HEK do que na preparação derivada de células $\mathrm{CHO}$. 
Relativa à antenaridade das estruturas das 3 preparações de hTSH em análise, enquanto no hTSH-CHO e no hTSH-Pit a predominância foi de estruturas biantenárias, no hTSH-HEK a predominância foi de estruturas triantenárias, uma diferença de frequência destas estruturas nas 2 outras preparações de $56,9 \%$ e $55 \%$ respectivamente.

Não foram encontradas no hTSH-HEK estruturas contendo $\mathrm{N}$-acetil galactosamina (GalNac) ao contrário do esperado, por se tratar de um célula de origem humana, analogamente ao que ocorre na preparação nativa.

Os 3 sítios de glicosilação do hTSH não estão sempre totalmente ocupados. Com relação à ocupância do hTSH-HEK, foi observada uma pequena diferença (4\%) com relação ao hTSH$\mathrm{CHO}$ e $\sim 18 \%$ de diferença na ocupância relativa ao hTSH-Pit. A ocupância das glicoproteínas pode ser clinicamente relevante, uma vez que pode estar associada a doenças que afetam a síntese, transferência ou processamento dos glicanos. Por exemplo a CDG tipo 1(Congenital Disorders of Glycosylation) é uma síndrome que provoca defeitos nas etapas iniciais do processo de glicosilação gerando sítios não ocupados (Tian Y \&Zhang H, 2010).

Relativo ao tempo de permanência da proteína na circulação, observou-se que o $t_{1 / 2}$ do hTSH-HEK foi o menor das 3 preparações analisadas. Isto possivelmente está ligado ao nível de sialilação destas preparações, uma vez que o ácido siálico ligado à proteína impossibilita o seu reconhecimento pelos receptores asialo-glicoproteícos existentes no fígado e que são responsáveis diretos pela depuração metabólica da proteína, sendo a taxa de depuração inversamente proporcional ao grau de sialilação. Desta forma, a preparação hTSH-HEK, que tem o menor grau de ácido siálico, foi a que foi depurada mais rapidamente da circulação. (Thotakura NR, 1992; Szkudlinski MW, 1993; Thotakura NR, 1995; Takamatsu S, 2003 ;). Nossos resultados de $\mathrm{t}_{1 / 2}$ das diferentes preparações de $\mathrm{hTSH}$ mostraram uma alta e significativa correlação com a quantidade de ácido siálico (mol/mol): $\mathrm{r}=0,9971 \mathrm{p}<0,001$.

A atividade biológica do hTSH-HEK mostrou-se menor que a do hTSH-CHO e hTSHPit. Este resultado está coerente com aquele obtido no estudo de farmacocinética em que a menor exposição do hTSH ao organismo foi do hTSH-HEK (AUC = $12194 \mu \mathrm{g} \cdot \mathrm{min} / \mathrm{mL})$. Também o hTSH-Pit mostrou-se menos ativo que o hTSH-CHO, o que está de acordo com 
relatos da literatura (Thotakura NR e col.,1991; Szkudlinski MW e col., 1993; Mendonça F e col., 2005; Oliveira JE e col., 2007; Damiani R e col., 2013). Nossos resultados mostraram uma alta e significativa correlação da atividade biológica com a meia vida circulatória $(r=0,9965$ $\mathrm{p}<0,001)$ e com a quantidade de ácido siálico $(\mathrm{r}=0,9999 \mathrm{p}<0,001)$. Preparações com baixo teor de ácido siálico permanecem um tempo menor na circulação comparadas àquelas com maior teor de ácido siálico e menor é a sua atividade biológica in vivo.

Vale ressaltar a precisão do ensaio biológico realizado neste estudo, com coeficiente de variação $<16 \%$, uma variabilidade considerada pequena, tratando-se de ensaio biológico in vivo com animais.

Em conclusão, os resultados alcançados no presente trabalho mostram que a utilização das células HEK293T como hospedeiras é uma alternativa viável para a expressão de tireotrofina humana recombinante. O produto gerado satisfaz critérios de identidade, pureza e potência necessários para suportar seu uso como reagente químico, seja para uso in vitro (como reagente de imunoensaios), assim como para bioensaios, estudos de biodistribuição ou ainda em estudos de estrutura-função. A principal vantagem desta expressão é ser de origem humana, aproximando-se da proteína nativa. Também a maior rapidez e praticidade em sua obtenção por transfecção transiente é de interesse para a evolução de estudos sobre este hormônio. 


\section{CONCLUSÕES}

- Foi obtida pela primeira vez a tireotrofina humana recombinante derivada de células embrionárias de rim humano (HEK293T), biologicamente ativa e de alta qualidade.

- Não foram observadas diferenças significativas com relação à massa molecular entre o hTSHHEK, o hTSH derivado de células CHO e a preparação nativa.

- Foram encontradas diferenças substanciais nas estruturas dos $\mathrm{N}$-glicanos da tireotrofina humana recombinante derivada de células HEK293T, derivada de células CHO e da preparação nativa, especialmente no que se refere à sialilação, fucosilação e antenaridade das mesmas.

-O hTSH-HEK foi depurado mais rapidamente que o hTSH-CHO e que o hTSH-Pit.

- O hTSH-HEK mostrou-se 1,6 vezes menos potente que o hTSH-CHO e 1,2 vezes menos potente que o hTSH-Pit

- A expressão transiente de hTSH em células HEK 293T é uma alternativa potencialmente viável para se obter, de maneira rápida, um produto com atributos adequados de identidade, pureza e potência para o uso em estudos deste hormônio. 


\section{REFERÊNCIAS BIBLIOGRÁFICAS}

1. Adam E, Sarrazin S, Landolfi C, Motte V, Lortat-Jacob H, Lassalle P, Delehedde, M. Efficient long-term and high-yielded production of a recombinant proteoglycan in eukaryotic HEK293 cells using a membrane-based bioreactor. Biochem. Biophys. Res. Commun., v. 369, p. 297-302, 2008.

2. Almeida B E, Damiani R, Oliveira J E, Dalmora S L, Torjesen P A. Reversedphase high performance liquid chromatography as an alternative to animal bioassay for human thyrotropin potency determination. Anal.Meth., v. 6, p. 6688-6694, 2014.

3. Almo SC, Love JD. Better and faster: improvements and optimization for mammalian recombinant protein production. Curr. Opin. Struct. Biol., v.26, p.39-43, 2014.

4. Bandaranayake AD, Almo SC. Recent advances in mammalian protein production. FEBS Letters, v.588, p. 253-260, 2014.

5. Beckliwal G, Hildinger M, Hasija V, Wurm FM. High-Density Transfection with HEK293 cells allows doubling of transient titers and removes need for a priori DNA complex formation with PEI. Biotecnol. Bioeng., v.99, p.721-727, 2008

6. Belin V, Rousselle P. Production of recombinant expressed laminin fragment by HEKEBNA cells cultured in suspension in a dialysis bioreactor. Prot. Express. Purif., v.48, p.43-48, 2006.

7. Böhn E, Seyfried BK, Dockal M, Graninger M, Hasslacher M, Neurath M, Konetschny C, Matthiessen P, Mitterer A, Scheiflinger F. Differences in N-glycosylation of recombinant human coagulation factor VII derived from BHK, CHO, and HEK293 cells. BMC Biotechnol., v. 15, p. 87-101, 2015.

8. Carvalho CM, Oliveira JE, Almeida BE, Ueda EKM, Torjesen, PA, Bartolini P, Ribela, MTCP. Efficient isolation of the subunits of recombinant and pituitary glycoprotein hormones. J. Chromatogr. A, v. 1216, p. 1431-1438, 2009.

9. Casademunt E, Martinelle K, Jernberg M, Winge S, Tiemeyer M, Biesert L, Knaub S, Walter O, Schröder. The first recombinant human coagulation factor VIII of human origin: human cell line and manufacturing characteristics. Eur. J. Haematol, v. 89, p. 165-176, 2012.

10. Cervera L, Gutiérrez-Granados S, Berrow NS, Segura MM, Gòdia F. Extended gene expression by medium exchange and repeated transient transfection for recombinant protein production enhancement. Biotechnol. Bioeng., v. 112, p. 934-946, 2015 a. 
11. Cervera L, Fuenmayor J, González-Dominguez I, Gutiérrez-Granados S, Segura MM, Gódia F. Selection and optimization of transfection enhancer additives for increases virus-particles production in HEK293 suspension cultures. Appl. Microbiol. Biotechnol., v. 99, p. 9935-9949, 2015 b.

12. Cole ES, Lee K, Lauziere K, Kelton C, Chappel S, Weintraub B, Ferrara D, Peterson P.; Bernasconi R, Edmunds T, Richards S, Dickrell L, Kleeman.; MC Phersin JM, Pratt B. Recombinant human thyroid stimulating hormone: development of a biotechnology product for detection of metastatic lesions of thyroid carcinoma, Bio-Technol., v.11, p.1014-1023,1993.

13. Croset A, Delafosse L, Gaudry JP, Arod C, Glez L, Losberger C, Begue D, Krstanovic A, Robert F, Vilbois F, Chevalet L, Antonsson B. Differences in the glycosylation of recombinant proteins expressed in HEK and CHO cells. J. Biotechnol, v. 161, p. 336$348,2012$.

14. Damiani R, Oliveira JE, Vorauer-Uhl K, Peroni CN, Vianna EG, Bartolini P, Ribela MTCP. Stable expression of a human-like sialylated recombinant thyrotropin in a Chinese hamster ovary cell line expressing alpha 2,6-sialyltransferase. Protein Express. Purif., v. 67, p. 7-14, 2009.

15. Damiani R. Almeida B E, Oliveira J E, Bartolini P, Ribela M T C P. Enhancement of human thyrotropin synthesis by sodium butyrate addition to serum-free $\mathrm{CHO}$ cell culture. Appl. Biochem. Biotechnol, v. 171, p. 1658-1672, 2013.

16. Datta P, Linhardt, RJ, Sharfstein ST. An omics approach towards $\mathrm{CHO}$ cell engineering. Biotechnol. Bioeng., v. 110, p 1255-1262, 2013.

17. Dumont JA, Liu T, Low SC, Zhang X, Kamphaus G., Sakorafas P, Fraley C, Drager D, Reidy T, McCue J, Franck HWG, Merricks EP, Nichols TC, Bitonti AJ, Pierce GF, Jiang H. Prolonged activity of a recombinant factor VIII-Fc fusion protein in hemophilia A mice and dogs. Blood, v.119,p. 1-34, 2002.

18. Durocher Y, Butler M. Expression systems for therapeutic glycoprotein production. Curr. Opin. Biotechnol., v. 20, p. 700-707, 2009.

19. Fischer S, Charara N, Gerber A, Wolfel J, Shiedner G, Voedisch B, Geisse S. Transient recombinant protein expression in a human ammiocyte cell line: CAP-T1 cell system. Biotechnol. Bioeng.,v. 109, p.2250-2261, 2012

20. Fliedl L, Grillari J, Grillari-Vouglauer R. Human cell lines for the production of recombinant proteins: on the horizon. New Biotechnol., v.32, p. 673-679, 2015. 
21. Fogli, A.; Merle, C.; Roussel, V.; Schiffmann, R.; Ughetto, S.; Theisen, M.; BoespflugTanguy, O. CSF N-glycan profiles to investigate biomarkers in brain developmental disorders: application to leukodystrophies related to elF2B mutations. PLoS ONE, v.7, e42688, 2012.

22. Gawlitzek M, Estacio M, Fürch T, Kiss R. Identification of cell culture conditions to control N-glycosilation site-occupancy of recombinant glycoproteins expressed in $\mathrm{CHO}$ cells. Biotechnol. Bioeng., v. 103, p. 1164-1175, 2009.

23. Geisse S. Reflections on more than 10 years of TGE approaches. Protein Express. Purif., v. 64, p. 99-107, 2009.

24. Green ED, Baenziger JU. Asparagine-linked oligosaccharides on lutropin, follitropin, and thyrotropin. I. Structural elucidation of the sulfated and sialylated oligosaccharides on bovine, ovine, and human pituitary glycoprotein hormones. J. Biol. Chem., v. 263, p. 25-35, 1988.

25. Jing Y, Quian Y, Li ZJ Sialylation enhancement of CTLA4-Ig fusion in Chinese hamster ovary cells by dexamethasome. Biotechnol. Bioeng., v.107, p.488-496,2010.

26. Lin C-Y, Huang Z, Wen W, Wu A, Wang C, Niu L. Enhancing protein expression in HEK-293 cells by lowering culture temperature. PloS ONE, v.10 e0123562, 2015.

27. Loignon M, Perret S, Kelly J, Boulais D, Cass B, Bisson L, Alfkhamizarreh F, Durocher Y. Stable high volumetric production of glycosylated human recombinant IFNalpha2b in HEK293 cells. BMC Biotechnol., v. 8, p. 1-16, 2008.

28. Mendonça F, Oliveira JE, Bartolini P, Ribela MTCP. Two-step chromatographic purification of recombinant human thyrotrophin and its immunological, biological, physico-chemical and mass spectral characterization. J. Chromatogr. A, v.1062, p.103$112,2005$.

29. Oliveira JE, Mendonça F, Peroni CN, Bartolini P, Ribela MTCP. Determination of chinese ovary cell-derived recombinant thyrotropin by reversed-phase liquid chromatography. J. Chromatogr. B, v. 787, p. 345-355, 2003.

30. Oliveira JE, Damiani R, Bartolini P, Ribela MTCP, Practical reversed-phase high performance liquid chromatography method for laboratory scale purification of recombinant human thyrotropin. J. Chromatogr. A, v.1164, p. 206-211, 2007.

31. Oliveira JE, Damiani R, Bartolini P, Ribela MTCP, Influence of a reduced CO2 environment on the secretion yield, potency and N-glycan structures of recombinant thyrotropin from CHO cells. Mol. Biotechnol., v. 39, p. 159-166, 2008. 
32. Peroni CN, Soares CRJ, Gimbo E, Morganti L, Ribela MTCP, Bartolini P. High-level expression of human thyroid-stimulating hormone in chinese hamster ovary cells by cotransfection of dicistronic expression vectors followed by a dual-marker amplification strategy. Biotechnol. Appl. Biochem., v. 35, p. 19-26, 2002.

33. Pharm PL, Perret S, Cass B, Carpentier E, St-Laurent G, Bisson L, Kamen A, Durocher Y. Transient gene expression in HEK293 cells: Peptone addition post transfection improves recombinant protein synthesis. Biotechnol. Bioeng., v. 90, p. 333-334, 2005.

34. Picanço-Castro V, Biaggio R T, Cova D T, Swiech K. Production of recombinant therapeutic protein in humans cells: current achievements and future perspectives. Protein Pept. Lett., v. 20, p. 1373-1381, 2013.

35. Ribela MTCP, Bianco AC, Bartolini P. The use of recombinant human thyrotropin produced by chinese hamster ovary cells for the preparation of immunoassay reagents. J. Clin. Endocrinol. Metab., v. 81, p. 249-256, 1996.

36. Ribela MTCP, Gout PW, Bartolini P. Synthesis and chromatographic purification of recombinant human pituitary hormones. (Review) J. Chromatogr. B, v. 790, p. 285-316, 2003.

37. Ribela MTCP, Gout PW, Oliveira JE, Bartolini P. HPLC analysis of human pituitary hormones for pharmaceutical applications (Review). Curr. Pharm. Anal., v. 2, p. 103126, 2006.

38. Ribela MTCP, Damiani R, Silva FD, Lima ER, Oliveira JE, Peroni CN, Torjesen PA, Soares CR, Bartoloni P. N-glycoprofiling analysis for carbohydrate composition and site-occupancy determination in a poly-glycosylated protein: human thyrotropin of diferent origins. Submetido à Int. J. Mol. Sci., 2016.

39. Schuman S. Novel approach to molecular cloning and polinucleotide synthesis using vaccinia DNA topoisomerase. J. Biol. Chem., v. 269, p. 32678-32684, 1994.

40. Silva MA, Valgode FGS, Gonzalez JÁ, Yoriyaz H, Guimarâes MICC, Ribela MTCP, Buchjeiguel CA, Bartolini P, Okazaki K. Cytogenetic and dosimetric effects of $\mathrm{I}^{131}$ in patient with differentiated thyroid carcinoma: comparison between stimulation with rhTSH and thyroid hormone withdrawal treatments. Radiat. Environ.Biophys., v . 55, p. 317-328, 2016.

41. Simpson DZ, Hitchen PG, Elmhirst EL, Taylor ME. Multiple interactions between pituitary hormones and the mannose receptor. Biochem. J, v. 343, p. 403-411, 1999. 
42. Sun X, Goth PE, Wong KTK, Mori T, Yap MGS. Enhancement of transient gene expression by fed-batch culture of HEK 293 EBNA1 cells in suspension. Biotechnol, Lett., v. 28, p. 843-848, 2006.

43. Szkudlinki MW, Thotakura NR, Bucci I, Joshi LR, Tsai A, East-Palmer J, Shiloach J, Weintraub BD. Purification and characterization of recombinant human thyrotropin (TSH) isoforms producded by Chinese-hamster ovary cells - the role of sialylation and sulfatation in TSH bioactivity. Endocrinology, v.133, p. 1490-1500, 1993.

44. Szkudlinki MW, Thotakura NR, Tropea JE, Grossmann M, Weintraub BD. Asparaginelinked oligosaccharide structures determine clearance and oligodistribution of pitutitary and recombinant thyrotopin. Endocrinology, v. 136, p. 3325-3330, 1995.

45. Szkudlinki MW, Fremont V, Ronin C, Weintraub BD. Thyroid-stimulating hormone and thyroid-stimulating hormone receptor structure-function relationships. Physiol. Rev., v. 82, p. 473-502, 2002.

46. Swiech K, Picanço-Castro V, Covas DT. Human cells: New Plataform for recombinant therapeutic production. Protein Express. Purif., v.84, p. 147-153, 2012.

47. Takamatsu S, Fukuta K, Asanagi M, Abe R, Yokomatsu T, Fujibayashi Y, Makino T. Monitoring biodistribution of glycoproteins with modified sugar chains. Biochem. Biophys. Acta, v. 1622, p. 179-191, 2003.

48. Thotakura NR, Desai RK, Bales LG, Cole ES, Pratt BM, Weintraub BD. Biological activity and metabolic clearance of a recombinant thyrotropin produced in Chinese hamster ovary cells. Endocrinology, v. 128, p. 341-348, 1991.

49. Thotakura NR, Desai RK, Szkudlinski MW, Weintraub BD. The role of the oligosaccharide chains of the thyrotropin alpha-subunit and beta-subunit in hormone action. Endocrinology, v. 131, p. 82-88, 1992.

50. Thotakura NR \& Blithe DL. Glycoprotein hormones: glycobiology of gonadotropins, thyrotropin and free $\alpha$ subunit. Glycobiology, v. 5, p. 3-10, 1995.

51. Tian Y \& Zhang H. Glycoproteomics and clinical applications. Proteomics Clin. Appl., v. 4, p. 124-132, 2010.

52. Zhang P, Tan DL, Heng D, Wang T, Yang MY, Song Z. A functional analysis of Nglycosylation-related genes on sialylation of recombinant erythropoietin in six commonly used mammalian cell lines. Metab. Eng., v. 12, p.526-536, 2010.

53. Wajih N, Owen J, Wallin R. Enhanced Functional Recombinant Factor VII Production by HEK 293 Cells stably transfeted with VKORC1 where the gamma-carboxylase 
inhibitor calumenin is stably supressed by shRNA transfection. Thromb. Res., v.122, p. 405-410, 2008. 